NBER WORKING PAPER SERIES

\title{
LONG-TERM AND INTERGENERATIONAL EFFECTS OF EDUCATION: EVIDENCE FROM SCHOOL CONSTRUCTION IN INDONESIA
}

\author{
Richard Akresh \\ Daniel Halim \\ Marieke Kleemans \\ Working Paper 25265 \\ http://www.nber.org/papers/w25265 \\ NATIONAL BUREAU OF ECONOMIC RESEARCH \\ 1050 Massachusetts Avenue \\ Cambridge, MA 02138 \\ November 2018
}

We thank Manuela Angelucci, Catia Batista, Sylvie Lambert, Nicholas Li, Leigh Linden, Karen Macours, Edward Miguel, Adam Osman, Dean Spears, Rebecca Thornton, Pedro Vicente, and seminar participants at the University of Texas at Austin, Paris School of Economics, Universidade Nova de Lisboa, NEUDC at Cornell University, and University of Illinois at Urbana-Champaign for many helpful discussions and suggestions. All errors remain our own. The views expressed herein are those of the authors and do not necessarily reflect the views of the National Bureau of Economic Research.

NBER working papers are circulated for discussion and comment purposes. They have not been peer-reviewed or been subject to the review by the NBER Board of Directors that accompanies official NBER publications.

(C) 2018 by Richard Akresh, Daniel Halim, and Marieke Kleemans. All rights reserved. Short sections of text, not to exceed two paragraphs, may be quoted without explicit permission provided that full credit, including $(\subset$ notice, is given to the source. 
Long-term and Intergenerational Effects of Education: Evidence from School Construction in Indonesia

Richard Akresh, Daniel Halim, and Marieke Kleemans

NBER Working Paper No. 25265

November 2018

JEL No. I2,J13,J62,O15,O22

\begin{abstract}
In 1973, the Indonesian government began one of the largest school construction programs ever. We use 2016 nationally representative data to examine the long-term and intergenerational effects of additional schooling as a child. We use a difference-in-differences identification strategy exploiting variation across birth cohorts and regions in the number of schools built. Men and women exposed to the program attain more education, although women's effects are concentrated in primary school. As adults, men exposed to the program are more likely to be formal workers, work outside agriculture, and migrate. Households with parents exposed to the program have improved living standards and pay more government taxes. Education benefits are transmitted to the next generation. Increased parental education has larger impacts for daughters, particularly if mothers are exposed to school construction. Intergenerational results are driven by changes in the marriage partner's characteristics, with spouses having more education and improved labor market outcomes.
\end{abstract}

Richard Akresh

Department of Economics

University of Illinois at Urbana-Champaign

1407 West Gregory Drive

214 David Kinley Hall

Urbana, IL 61801

and NBER

akresh@illinois.edu

Daniel Halim

Department of Economics

University of Illinois at Urbana-Champaign 1407

West Gregory Drive

214 David Kinley Hall

Urbana, IL 61801

dzhalim2@illinois.edu
Marieke Kleemans

Department of Economics

University of Illinois at Urbana-Champaign

1407 West Gregory Drive

214 David Kinley Hall

Urbana, IL 61801

kleemans@illinois.edu 


\section{Introduction}

The questions of which adult outcomes are affected by increases in educational attainment and whether these effects persists into the next generation are of great policy importance and broad research interest. Governments in developing countries spend approximately one trillion dollars annually on education, and households are estimated to spend hundreds of billions more on the education of their children (Glewwe and Muralidharan, 2016). While much of the government spending is motivated by the belief that increases in education will translate to higher economic development and growth, the causal effect of schooling on economic growth is not uncontested. ${ }^{1}$ An extensive literature in macroeconomics and growth has pointed to a high correlation between cross-country differences in per capita income and in education, but some have argued that these may reflect reverse causality of increased educational attainment in anticipation of high rates of economic growth (Bils and Klenow, 2000). ${ }^{2}$

Microeconomic analyses of the returns to schooling date back to Gorseline (1932) and Walsh (1935) and have long recognized that without (quasi) exogenous variation in educational attainment, the causal impact of education is hard to estimate because the choice of how much education to obtain is correlated with a large number of individual, household, and community characteristics. In recent years, major strides forward have been made using randomized experiments, but reviewing 111 primary school interventions in developing countries, McEwan (2015) finds that only 10 percent had any evaluation taking place more than one month after the

\footnotetext{
${ }^{1}$ In the early nineties, theories endogenizing technology (such as Romer, 1990 and Grossman and Helpman, 1991) were motivated by the belief that cross-country differences in human capital could not quantitatively explain the differences in levels and growth rates of per capita output (Klenow and Rodriguez-Clare, 1997, 2005). Several later empirical papers challenge that belief showing that a Solow model augmented to include human capital can explain the lion's share of cross-country variance in output per capita (Mankiw, Romer, and Weil, 1992; Young, 1994, 1995; Barro and Sala-i-Martin, 1995).

${ }^{2}$ Foster and Rosenzweig (1996) also find evidence of this direction of causality by documenting that Indian provinces that benefited from the Green Revolution saw increases in returns to, and enrollment in, schooling.
} 
intervention had ended. ${ }^{3}$ While the focus on measuring early life outcomes is understandable given that primary education provides the foundation for subsequent educational attainment, the ultimate goal is improvements in later life outcomes and overall economic development.

In this paper, we study the causal impact of one of the largest primary school construction programs ever completed on a wide range of long-term and intergenerational outcomes, including those related to education, employment, migration, living standards, taxes, marriage, health, housing and assets. Between 1973 and 1979, the Indonesian government constructed over 61,000 primary schools, averaging two schools per 1,000 children of primary school age. We use 2016 nationally representative Indonesian data to examine the long-term and intergenerational effects of additional schooling as a child. Following the seminal work by Duflo (2001) who studies the effects of this school construction program on men's education and earnings in 1995, we employ a difference-in-differences strategy, exploiting variation across geographic regions in the number of schools built and across birth cohorts in their exposure to the schools.

The paper makes the following contributions. First, we estimate the causal impact of the school construction program on an extensive range of outcomes, many of which researchers have not previously studied. Second, we do so at a time that those exposed to the program are in their forties and fifties, giving us a unique look at the persistence of the effects over time. This type of long-term analysis is important for policy evaluation, but is uncommon and existing evidence on the persistence of education interventions is mixed. ${ }^{4}$ Third, the long time horizon and detailed

\footnotetext{
${ }^{3}$ Notable exceptions include Baird, Hamory Hicks, Kremer, and Miguel (2016) who show positive labor market impacts 10 years after a deworming intervention in Kenya, and Gertler et al. (2014) showing higher earnings 20 years after an early child stimulation program in Jamaica. Evidence from the U.S. indicates preschool and kindergarten programs lead to improved adult outcomes (Garces, Thomas, and Currie, 2002; Heckman et al., 2010; Chetty et al., 2011) as do health interventions (Bhalotra and Venkataramani, 2018).

${ }^{4}$ For example, Evans and Ngatia (2018) find that positive outcomes from a free school uniform program fade out over time and are no longer observable eight years after the intervention. Andrabi et al (2011) using data from Pakistan find that only one-fifth to one-half of student learning persists between grades. Jacob, Lefgren, and Sims (2010) find low persistence of teacher learning in the U.S. with three-quarters or more fading out within one year.
} 
household-level data allow us to observe intergenerational effects on children whose parents are exposed to the program and study impacts on the children's educational attainment and wellbeing. ${ }^{5}$ Fourth, we extend the focus on working-age men in Duflo (2001) to also study the impact of school construction on women. This allows us to study gender differences for both the first and second generation outcomes and explore marriage market outcomes, which appear to play a crucial role in the intergenerational transmission of human capital. Finally, while most of the education research evaluates demand-side interventions, we study the impacts of a supply-side educational intervention, with large up-front costs and benefits dispersed over time. We perform a detailed cost-benefit analysis to calculate the internal rate of return, and using tax data, we evaluate whether school construction pays for itself with higher future government tax revenues.

Figure 1 provides an overview of our findings. Due to the data's richness and the large number of outcomes, we want to be careful to not overemphasize any single significant result and so we take two approaches. First, following Kling, Liebman, and Katz (2007), we create an index for each family of outcomes where we aggregate all individual outcomes in that family together. As described further in Section 3, we then estimate standardized effects from exposure to school construction on these outcome indexes (Banerjee et al., 2015). Second, since we examine multiple outcomes, we correct for the potential issue of simultaneous inference using multiple hypothesis testing. We calculate q-values using the Benjamini-Hochberg step-up method to control for the false discovery rate (Benjamini and Hochberg, 1995).

\footnotetext{
${ }^{5}$ Black and Devereux (2011) review the large literature on the intergenerational transmission of human capital that measures the persistence between parents' and children's educational attainment, while Currie (2011) and Almond and Currie (2011) provide a review of the long-term effect on education of negative shocks while in utero or early childhood. In addition to the focus on the estimation of correlations between parent and child educational outcomes, recently there is an increased emphasis on estimating causal relationships. Researchers have used changes in school compulsory laws (see Chevalier, 2004 for U.K; Black, Devereux, and Salvanes, 2005 for Norway; Oreopoulos, Page, and Stevens, 2008 for U.S.), other educational policies (Currie and Moretti, 2003; Maurin and McNally, 2008), and environmental shocks (Black et al., forthcoming) to estimate these effects. There is however limited evidence from developing countries.
} 
The consistent pattern seen in Figure 1 is that exposure to school construction improves most outcomes we are able to explore in the data. ${ }^{6}$ School construction, not surprisingly, leads to improved educational outcomes. Duflo (2001) previously showed this for men, and we now confirm it also improves women's education. ${ }^{7}$ The education effects for women are concentrated in primary school only, while men also see significant increases in lower and upper secondary education. As adults, men who are exposed to the program are more likely to be employed, to work in the formal sector, and to work in the non-agricultural sector, while the likelihood of migration increases for both men and women. Households in which either parent is exposed to the program have higher living standards, better housing, more assets, and pay more government taxes. While nutrition and health investments increase, we do not observe any improvements in health outcomes. School construction leads to improved marriage market outcomes with spouses being more educated, more likely to be literate, and more likely to have migrated.

Parents transmit these effects to the next generation, who have more education, with larger impacts in secondary and tertiary education. Parental exposure has larger impacts for daughters, particularly if the mother is exposed to the school construction program. We perform a mediation analysis indicating that the intergenerational transmission of human capital appears to be driven by changes in parents' marriage outcomes, especially whether the spouse completed primary school, is literate, and works in the formal sector and outside of agriculture.

To quantify the policy implications, we conduct a cost-benefit analysis in which we create an accounting model to calculate the discounted costs of school construction and

\footnotetext{
${ }^{6}$ An increase of one additional school built per 1,000 children would increase these indexes for those exposed to the school construction by 0.02 to 0.07 standard deviations relative to the control group.

${ }^{7}$ In addition to Duflo (2001) focusing on Indonesia, studies evaluating school construction projects have been carried out in Mozambique (Handa, 2002), Pakistan (Alderman, Kim, and Orazem, 2003), Afghanistan (Burde and Linden, 2013) and Burkina Faso (Kazianga et al., 2013). These studies focus on improvements in enrollment rates, as opposed to later-life outcomes, and all confirm large increases in school enrollment.
} 
subsequent benefits for the government in terms of increased tax revenues and overall improved living standards for the Indonesian population. Across a range of different parameter estimates, we find that school construction leads to increased government tax revenues that directly offset construction costs in most cases within 40 years. Furthermore, accounting for improved living standards of the Indonesian population reveals high internal rates of return ranging from 13-21 percent and benefits surpassing costs within 17-30 years after the schools were built. These results provide strong support for the cost-effectiveness of supply-side interventions. ${ }^{8}$

The rest of this paper is organized as follows. Section 2 describes the institutional context and school construction program in Indonesia. Section 3 describes the empirical identification strategy and the data. Section 4 presents the results examining the effects of exposure to school construction on a range of long-term outcomes and Section 5 discusses the intergenerational effects. Section 6 shows results of a number of robustness checks. Section 7 presents the costbenefit analysis and Section 8 concludes.

\section{Institutional Context}

Indonesia is the fourth most populous country in the world and the seventh largest economy in terms of total GDP at purchasing power parity. The country has experienced over 40 years of high economic growth. Beginning from Soeharto’s rise to power in 1967, Indonesia’s Ministry of National Development Planning (Bappenas) outlined their plans for national development and

\footnotetext{
${ }^{8}$ Recent education research has typically focused on evaluating demand-side interventions that include either information-based interventions (see Jensen, 2010 for the first study of this type that provided information to parents about the returns to schooling), cash transfer programs (see Fiszbein et al. 2009 for an overview; Behrman, Parker, Todd, 2011 for evidence on the medium-term impacts of the Mexican conditional cash transfer program Progresa; Parker and Vogl, 2017 for evidence on Progresa’s long-term impacts; Baird et al., 2011, Akresh, de Walque, and Kazianga, 2013, 2016; and Benhassine et al., 2015 for research that explores the role of conditionality in these cash transfer programs), scholarship programs (see Kremer, Miguel, and Thornton, 2009 for one of the first studies to examine the impact of merit-based scholarships), or other household level interventions (see Oster and Thornton, 2011 for evidence on providing female sanitary products to secondary school girls; and Muralidharan and Prakash, 2017 for evidence from providing bicycles to families).
} 
the reduction of poverty in a series of Five-Year Development Plans (Repelita). One important part of these plans included the establishment of the "presidential instructions" (INPRES) program, which set up a system for distributing revenues from the central government to lower administrative levels. Starting with the oil boom in 1973, the central government emphasized the explicit goal of reducing regional disparities (Ravallion, 1988).

As part of this redistribution goal, the government began a nationwide school construction program, the Sekolah Dasar INPRES, which was one of the first and largest INPRES programs. Between 1973 and 1979, around 61,800 primary schools were constructed. Enrollment rates in 1972 before the start of school construction were 71 percent among primary school-age children. By 1978, enrollment rates among this age group reached 85 percent. ${ }^{9}$ Prior to this program in 1973, capital expenditures in education were low and enrollment rates in the few years before school construction began were stagnant (World Bank, 1989).

School construction nearly doubled the stock of primary schools from a baseline of around 63,000 primary schools. On average, the program added over 200 schools per district or two schools for every 1,000 children of primary school age. There was large heterogeneity across districts in how many schools the government built as the government designed the school construction program to target regions in which enrollment was initially lower. ${ }^{10}$ The government designed each school for 120 students, and they recruited teachers and paid their salaries for these newly constructed schools. During the same period, the government attempted to train new teachers, and the percentage of teachers who met the minimum qualification of having an upper secondary school degree did not change over this period (World Bank, 1989).

\footnotetext{
${ }^{9}$ World Bank Databank. 2018. “Adjusted Net Enrollment Rate, Primary (\% of Primary School Age Children)” (Accessed on October 17, 2018: databank.worldbank.org)

${ }^{10}$ Appendix Figure A.1 presents a map of Indonesia indicating the geographical distribution of the number of schools constructed in each district.
} 


\section{Empirical Strategy and Data}

\subsection{Difference-in-differences}

Following Duflo (2001), we estimate a difference-in-differences specification in which an individual's region of birth and date of birth jointly determine their exposure to the INPRES school construction program. Children in Indonesia typically attend primary school between age seven and twelve. INPRES school construction started during the 1973-1974 school year, so children who were born in or before 1962 were at least 12 years of age in 1974 and would not have benefited from the school construction. ${ }^{11}$ Children younger than seven in 1974 would have been exposed to the full potential benefits of the newly constructed schools. Children who were of primary school age in 1974 might partially benefit from the new INPRES schools as some of them were induced to enroll, and their propensity to enroll likely decreased with the child's age.

Besides variation across birth cohorts, there is considerable variation across geographical regions in the intensity of the school construction program. This is because the number of schools constructed was linked to the regions' primary school enrollment rate in 1972 (prior to the school construction), and areas with low prior enrollment rates had more schools built.

Exploiting these two sources of variation (birth cohort and geographical), we estimate the effect of school construction in the following regression:

$$
y_{i j t}=\alpha+\beta \text { School }_{j} \cdot \text { Young }_{i t}+\left(\boldsymbol{X}_{j} \boldsymbol{B}_{t}^{\prime}\right) \gamma_{t}+\mu_{j}+\delta_{t}+\varepsilon_{i j t}
$$

where $y_{i j t}$ is the outcome of individual $i$ born in district $j$ in year $t, S c h o o l_{j}$ measures the number of schools constructed by the INPRES program between 1973 and 1979 per 1,000 children in the individual's birth district $j$. We use an individual's birth district instead of current residence

\footnotetext{
11 The 1993 Indonesian Family Life survey indicates that less than 3 percent of individuals born between 1950 and 1962 were still in primary school in 1974. As a further check, we use the 1976 Intercensal Survey and find that only 4.3 percent of individuals born between 1950 and 1962 were still in primary school in 1976.
} 
because the latter may be endogenous to program placement if households move to access schools for their children. ${ }^{12}$ Young $_{i t}$ is an indicator variable for being born between 1968-1972 (ages 2-6 in 1974) and thus being young enough to benefit from the program. Individuals born between 1957 and 1962 (ages 12-17 in 1974) represent older cohorts who are not exposed to the program. Following Duflo (2001), we exclude individuals born between 1963 and 1967 (ages 711 in 1974) as they might have only partially benefited from school construction. We perform several robustness checks to confirm results are consistent across various definitions of exposed and unexposed cohorts. ${ }^{13} \mu_{j}$ are time-invariant district of birth fixed effects, $\delta_{t}$ are cohort of birth fixed effects, and $\boldsymbol{X}_{j} \boldsymbol{B}_{t}^{\prime}$ is intended to control for district-specific time-varying factors that might influence outcomes. Following Duflo (2001), we do this by interacting birth cohort indicators with district enrollment in 1971 and with the presence of water and sanitation programs in the district. ${ }^{14}$ Note that we closely follow Duflo (2001) with the only exceptions that, unlike Duflo, we cluster our standard errors, and we do so at the district level, and that our data allows us to estimate the effects of school construction on both men and women. To allow for gender heterogeneity, we estimate Equation (1) separately for men and women. ${ }^{15}$

\footnotetext{
${ }^{12}$ In the African context, child fostering, where the biological parents send their own child to live with another family, is quite common and often done to send the child to school (Akresh, 2004, 2009). In the Indonesian context, child fostering is much less common (Marazyan, 2012).

${ }^{13}$ One of the reasons for Duflo (2001) to restrict the young cohort to those born before 1972 is so that these cohorts would have completed schooling and begun participating in the labor market by 1995, the survey year of the data she uses. The 1972 cohorts turned 23 in 1995, which is old enough to have completed tertiary education. With our 2016 data, cohorts born after 1972 would have also been exposed to the school construction and had sufficient time to complete school and join the labor market. In the robustness checks discussed in Section 6, we explore the robustness of the results to alternative cohort definitions. In particular, we show that results are robust to adding in younger cohorts (born 1973-1980), older cohorts (born 1950-1956), and partially exposed cohorts (born 1963-1967).

${ }^{14}$ We use district enrollment in 1971 because program intensity was tied to 1972 district enrollment and not controlling for pre-program enrollment might bias the results as there could be mean reversion even in the absence of the program. In addition, the oil boom, which provided financial resources for school construction, could have also provided resources for other government programs that were correlated with INPRES school placement. Water and sanitation programs were the second largest set of INPRES programs delivered by the central government.

${ }^{15}$ Given the program targeted less developed areas, we want to show that our effects are not explained by general catching up (or mean reversion) from those areas, as this would violate the parallel trends assumption. To test this identification assumption, we estimate placebo regressions in which we compare the old cohort (ages 12-17 in 1974)
} 
We are able to explore both individual and household-level variables to examine impacts of exposure to school construction. For data collected at the household level, such as expenditures and assets, we use the birth cohort and region of birth of the household head or the spouse and present results in separate panels for men and women. ${ }^{16}$ In Equation (1), $j$ refers to the district of birth of the man or woman, while $t$ refers to their year of birth. ${ }^{17}$

The duration between school construction that started in 1973 and data collection in 2016 allows us to not only study the long-term effects of exposure to the program but also the effects of school construction on the next generation's outcomes. Specifically, we estimate the impact on children's schooling and other child outcomes based on whether their mother or father (or both) is exposed to school construction. We estimate reduced-form relationships between second generation outcomes and schools construction in the following regression:

$$
y_{i j t c a}=\alpha+\beta \text { School }_{j} \cdot \text { Young }_{i t}+\left(\boldsymbol{X}_{j} \boldsymbol{B}_{t}^{\prime}\right) \gamma_{t}+\mu_{j}+\delta_{t}+\theta_{a}+\varepsilon_{i j t c a}
$$

where $y_{i j t c a}$ denotes the outcome of child $c$ who is age $a$, born to a parent $i$ who was born in district $j$ in year $t, S_{c h o o l}$ is the number of schools constructed in the father's or mother's birth

with an even older cohort (ages 18-24 in 1974). Results are discussed in Section 6 and show there are no differential time trends in outcomes prior to the school construction. Further, in Appendix Figure A.2, we estimate a regression where we interact the number of INPRES schools constructed in one's birth district with an indicator for age in 1974. We omit the age group 19-24 in 1974 from the regression so that we are comparing each age against this older cohort. For both men and women, we do not observe any differential trend effects for non-exposed ages.

${ }^{16}$ Female household heads represent 13.8 percent of the sample and are included in the regressions for women. Results are robust to estimating the regressions separately for household heads and spouses, irrespective of gender. Note that in the household level regressions the analysis for men does not condition on the women's exposure to school construction. Likewise, for women, the analysis does not condition on the men's exposure.

${ }^{17}$ This assignment is arguably the most natural way to define exposure for household-level outcomes as it is possible to have multiple individuals living in a household and these individuals could be in the old, young, and intermediate birth cohorts. For example, a household with the household head born in 1962, his wife born in 1968, his younger brother born in 1965, and his sister-in-law born in 1970 would yield potentially four individuals of which one is in the old cohort (1957-1962), one in the intermediate cohort (1963-1967), and two in the young cohort (1968-1972). Robustness checks in Section 6 show that this assignment decision does not influence results. 
district, Young $_{i t}$ indicates if the father or mother belongs to the young cohort, and $\theta_{a}$ is child c's age fixed effect. ${ }^{18}$ Standard errors are clustered at the father's or mother’s birth district. ${ }^{19}$

\subsection{Strategies to address the large number of outcomes}

We adopt two strategies to address the large number of outcomes that we examine to avoid overemphasizing any single significant result. First, as mentioned in the introduction, we create indexes for each family of outcomes following Kling, Liebman, and Katz (2007). These indexes combine all of the outcomes in each family of outcomes. To construct the indexes, we define each outcome so that higher values correspond with better outcomes. Then we standardize each outcome into a Z-score by subtracting the mean and dividing by the standard deviation of the older cohort born in low intensity regions. We then average all of the Z-scores and standardize the average relative to the older cohort born in the low intensity regions. ${ }^{20}$ We then estimate the effect of exposure to the school construction program on these standardized outcome indexes.

Second, we correct for the potential issue of simultaneous inference using multiple hypothesis testing. Following Benjamini and Hochberg (1995), we use the concept of a false discovery rate (FDR) to allow inference when conducting many tests. Intuitively, FDR allows a researcher to tolerate a certain number of tests to be incorrectly discovered. An FDR adjusted qvalue of 0.05 implies that 5 percent of significant tests result in false positives compared with an unadjusted p-value of 0.05 that implies 5 percent of all tests result in false positives. In all

\footnotetext{
${ }^{18}$ We include child age fixed effects because old cohort parents mechanically have older children on average than young cohort parents and older children have more time to complete additional schooling. Therefore, the marginal benefit to children's years of schooling is estimated across different households but among children of the same age. ${ }^{19}$ As is common in household surveys, Susenas 2016 identifies all household relationships with respect to the household head. If a child is not the biological or adopted child of the household head and spouse, the child will be recorded as 'other household member'. Therefore, our intergenerational analysis is restricted to children of the household head and spouse.

${ }^{20}$ This is the approach used by Banerjee et al. (2015) in evaluating the effect of poverty graduation programs across six different countries on a range of outcomes. Ajayi and Ross (2017) who are not evaluating a randomized control trial modify this standardization approach to use with a difference-in-difference empirical identification strategy that does not have a randomly assigned control group.
} 
regression tables, we show standard errors based on unadjusted p-values and FDR adjusted q-

values that address the multiple hypotheses being tested in a given family of outcomes.

\subsection{Data}

To measure the impact of this school construction program, we use Duflo's data of the Sekolah

Dasar INPRES program that reports the number of schools constructed in each district between

1973 and $1979 .{ }^{21}$ We combine the data on school construction with the National Socioeconomic Survey conducted in 2016, henceforth Susenas 2016, which is administered by Indonesia’s

Central Statistics Bureau, Badan Pusat Statistik. Susenas 2016 is a nationally representative household survey that covers all 34 provinces and 511 districts of Indonesia. ${ }^{22}$ The data combines a large sample size of 291,414 households and 1,048,575 individuals with a wide range of variables, including on education, employment, migration, living standards, taxes, housing and assets, nutrition, health, marriage market and demographic outcomes, welfare program participation, and educational outcomes for the next generation. ${ }^{23}$

Summary statistics are presented for each family of outcomes in Tables 1 to 7 and Appendix Tables A.1 to A.5, which we discuss in the next section together with the impacts of school construction. For the birth cohorts that our analysis focuses on (1957-1962 and 19681972), households have on average over four members and the sample is evenly split between men and women. Average completed years of schooling for individuals in these cohorts is 8.0 years for men and 7.1 years for women. Approximately 81 percent of men and 73 percent of

\footnotetext{
${ }^{21}$ We are grateful to Esther Duflo for sharing these data.

22 The smallest geographical unit in the Susenas 2016 is the Indonesian 'kabupaten', loosely translated as district.

${ }^{23}$ Susenas 2016 is particularly suitable to study the effects of the school construction program because it includes information on the individual's district of birth and because the sample is large enough to be able to precisely estimate the observed relationships. Appendix B provides further rationale for the choice of data, in particular showing that the sample for the Indonesia Family Life Survey (IFLS) is not large enough to detect the effects of school construction. This is confirmed by Bharati, Chin, and Jung (2018) who use the most recent round of the IFLS and argue it is underpowered to estimate the effect of school construction on education.
} 
women complete primary school. These individuals have lower rates of lower and upper secondary school completion (39 and 34 percent for men respectively and 31 and 26 percent respectively for women). Tertiary completion rates are 9.5 and 7.7 percent for men and women.

These individuals are ages 44 to 48 (young cohort) and 54 to 59 (old cohort) at the time of the survey in 2016. Most men are working (95 percent), while women have lower labor force attachment (64 percent). Conditional on working, only 33 percent of men and 24 percent of women are in the formal labor market. Just over half of men and women work in the nonagricultural sector and around one-quarter of them have migrated from their birth district.

\section{Results}

This section describes the impact of school construction on long-term and intergenerational outcomes. Following the estimation strategy previously outlined, the main explanatory variable is an interaction of the number of schools constructed per 1,000 children in a person's birth district with an indicator variable for being young enough to have benefitted from the program. As briefly discussed in the introduction, Figure 1 reveals broad positive impacts of school construction across indexes of outcomes for first generation individuals exposed to the program, and across indexes that capture second generation effects on their children. In the following sections, we discuss the family of outcomes that these indexes are based on in more detail.

\subsection{Impact on educational attainment}

Table 1 studies the relationship between school construction and educational attainment. ${ }^{24}$ On average, the program increases years of education for men by 0.27 years and for women by 0.23 years. At the mean number of schools built per 1,000 children (1.98), these estimates imply an increase in years of schooling of 0.53 and 0.46 for men and women, respectively. The analysis

\footnotetext{
${ }^{24}$ Educational outcomes are recorded for household members aged five and older and are missing otherwise.
} 
by Duflo (2001) is restricted to men, and the comparable point estimate in her study (0.19 years) is lower than ours. We can only speculate about the source of this difference, but both estimates are modest in size given that the number of primary schools almost doubled. ${ }^{25}$

The next four rows examine completed levels of education and show considerable gender differences. For men, the program increases the likelihood of completing primary school by 2.6 percentage points. Even though the program only targeted primary schools, effects for men are seen in lower and upper secondary education at 2.3 and 2.6 percentage points. These represent larger percentage increases than for primary school because average completion rates at these levels are lower. On the other hand, the results for women are concentrated in primary school only, which they are 4.1 percentage points more likely to complete, and we are able to reject the equality of this coefficient with the male effect. The effects on lower and upper secondary completion rates are considerably smaller and indistinguishable from zero. For both men and women, school construction did not affect tertiary education completion rates. As shown in row 6, literacy rates are high on average at 95 percent for men and 91 percent for women, and the program raises these by 1.5 and 3.3 percentage points, respectively. The FDR q-values (shown in square brackets) that correct for multiple hypothesis testing across all of the outcomes in the education table reveal that the coefficients remain statistically significant.

In the last row, we create an index using all other rows combined, following Kling et al. (2007) as discussed previously. The point estimates correspond with those shown in Figure 1 and confirm broad increases in educational attainment for men and women. Building two additional schools in an individual's birth district increases the educational outcomes for those exposed to the school construction by approximately 0.13 standard deviations relative to the control group.

${ }^{25}$ Similar to Duflo (2001), we also estimate the impact on average years of education for the sample of wage earners and for all those employed. Results are broadly similar in magnitude and statistical significance. 
The gender dynamics and patterns by grade are explored in further detail in Figure 2 showing the impact of school construction on the likelihood of completing at least a certain number of years of education. For example, it shows that the program increased the likelihood of completing at least one year of school by 0.95 percentage points for men and 2.3 percentage points for women. For men and women, effects are significantly different from zero throughout all primary school years and show an increasing pattern by grade. Consistent with Table 1 , effects for men continue throughout lower and upper secondary school and seem fairly stable across grades. While positive, the secondary school effects for women are not distinguishable from zero, nor are the effects on tertiary education for either gender. ${ }^{26}$

\subsection{Long-run labor market impacts}

Having observed large increases in education in response to school construction, Table 2 studies subsequent labor market and migration outcomes. ${ }^{27,28}$ As shown in row 1, 95 percent of men are working and the program raises this by 0.6 percentage points. The effect for women is half as large and insignificant, but allows for an economically meaningful increase within its confidence bounds, especially considering a lower average employment rate of 64 percent. In row 2, we explore the intensive margin of employment, namely number of hours worked conditional on working. Estimates indicate increases of 0.26 hours for men and 0.16 for women, but neither are significant. In response to school construction, men move to jobs that are generally deemed more

\footnotetext{
${ }^{26}$ While the school construction program could be used as an instrument for years of education, we prefer to study later-life outcomes using OLS in order to capture broad impacts and because the exclusion restriction could be violated if the program caused community-level changes that affect long-term outcomes in ways other than through increased schooling. There is a strong first stage relationship with an F-statistic of 32.3 for men and 31.8 for women. That said, for scaling purposes, the coefficients on long-term outcomes can be multiplied by four to calculate the effect of an extra year of education, given that the program increased schooling by approximately 0.25 years.

${ }^{27}$ Employment outcomes are recorded for household members aged ten and older and are missing otherwise.

${ }^{28}$ Heckman, Humphries, and Veramendi (2018) provide a recent overview of the extensive literature examining the relationship between education and labor market outcomes. Duflo, Dupas, and Kremer (2017) is one of the few randomized control trials in education that follows individuals over eight years and finds that secondary school scholarships improves labor market outcomes.
} 
desirable: they are 1.1 percentage points more likely to work in the formal sector that tends to offer higher quality and more stable jobs (Kleemans and Magruder, 2018). Given an average formal sector employment rate of 33 percent for men, increasing the number of schools in an individual's birth district by the sample mean raises the likelihood of men being in the formal sector by almost 7 percent. Men furthermore move away from agricultural work, which they are 1.2 percentage points less likely to hold, compared to 44 percent on average, and shift towards service sectors. We do not find any evidence of occupational shifts for women. ${ }^{29}$

Most research on the relationship between education and migration generally focuses on the selection into migration in terms of educational attainment. ${ }^{30}$ We extend this work by studying the causal relationship of increases in education on the likelihood of migration. On average, 27 percent of men and 25 percent of women migrate away from their birth district. School construction increases migration rates by 0.7 and 0.8 percentage points respectively. At the mean level of school construction, this represents an economically meaningful increase of 5.1 and 6.5 percent for men and women, respectively. Row 7 indicates that the increase in migration is concentrated in shorter distance moves within—rather than between—provinces.

Correcting for multiple hypothesis testing across all of the outcomes in the work/migration table shows that the FDR q-values are somewhat larger but coefficients generally remain statistically significant. Finally, aggregating the seven outcomes into an index following Kling et al. (2007) shows a positive and significant impact for men with an increase of 0.076 standard deviations due to an increase of two additional schools built in the district.

\footnotetext{
29 The only occupation-related variable that shows up as statistically significant for women is whether they are selfemployed in their own micro-enterprise, which almost a quarter of women are. They are 1.1 percentage points more likely to do so. Given the large number of outcomes variables, we decided not to report all subcategories separately, but instead combine them into the 'formal worker' variable, which is not statistically significant.

${ }^{30}$ Empirical evidence for Indonesia (Hicks et al., 2018) and for developing countries in general (Young, 2013) shows positive selection from rural to urban areas and negative selection from urban to rural.
} 


\subsection{Long-term impacts on living standards, taxes, housing, and assets}

Susenas 2016 collects detailed data on household expenditures, which we use as a proxy for living standards. ${ }^{31}$ Table 3 shows the effects of exposure to school construction on five aggregated living standard measures. Row 1 shows that total expenditure increases by 2.1 or 3.2 percent in households in which either males or females are exposed. The increase is larger for non-food than food expenditure (rows 2 and 3) and, as a result, the ratio of non-food to total increases (row 4). Households where the head or spouse is exposed spend 16 to 19 percent more on education in 2016 (row 5). All results remain statistically significant after correcting for multiple hypothesis testing. The last row combines the expenditure data from rows 1,2 , and 5 into a living standards index, showing an overall increase of 0.03 and 0.05 standard deviations for men and women, respectively, for each additional school built in one’s birth district. ${ }^{32}$

Given that income is generally correlated with expenditure, we expect improvements in labor market outcomes to go hand in hand with increases in expenditure. While this is true for men, we observe increased expenditure in the absence of labor market improvements for women. We explore this apparent puzzle in Appendix Table A.6. Note that labor market outcomes are observed for each individual while expenditure is measured at the household level, so household dynamics and spouse characteristics can interact with the direct effect of program exposure. Column 1 repeats the total expenditure regression and the other columns add spouse

\footnotetext{
${ }^{31}$ Susenas 2016 does not include information on income, unlike the 1995 Intercensal survey that Duflo (2001) used to measure the returns to education. After the 1995 round, the earnings question was discontinued so we do not have access to more recent income data. That said, Rizky, Suryadarma, and Suryahadi (2018) argue that expenditure is a better measure of living standards because income data tends to suffer from under-reporting in developing countries. All expenditure values refer to average monthly expenditure measured in 10,000 Indonesian rupiah (IDR). In 2016, the exchange rate was 1 USD=13,308 IDR. Expenditure categories that were reported in weekly or annual amounts are converted to monthly expenditure. In regression analyses, we apply an inverse hyperbolic sine transformation to the nominal values since expenditure data tends to be skewed and a log transformation would not be defined for zero expenditures. The inverse hyperbolic sine is approximately equal to $\log (2 y)$ or $\log (2)+\log (y)$, so in most cases it can be interpreted the same way as a standard logarithmic dependent variable.

${ }^{32}$ The variables shown in rows 3 and 4 of Table 3 can be derived from those shown in rows 1 and 2, so to avoid double counting these are excluded from the living standards index.
} 
characteristics as mediating variables. Controlling for spouse characteristics changes the direct effect of program exposure on expenditure: the effect of men's exposure drops significantly when controlling for his spouse's education-related variables but not when controlling for the wife's labor market outcomes. This is not surprising as we did not observe labor market effects for women. The effect for exposed women drops 30 to 50 percent not only when controlling for her husband's education but when controlling for his labor market outcomes. When controlling for all mediating variables in the last column, the direct effect falls by about 60 percent for both men and women. We interpret this as suggestive evidence that household dynamics and marriage market outcomes play an important role; an issue we return to in Section 4.5.

In addition to expenditures, we study tax payments, which are important for the costbenefit analyses in Section 7 and allow us to study if the program pays for itself from increased taxes over time. Table 4 shows broad increases in total taxes and the three tax sub-components that Susenas 2016 collects data on. Total taxes increase by 7.8 percent in households where males are exposed to school construction and 12.3 percent if women are exposed. In rows 2, 3, and 4, we analyze the three main sub-components of taxes, revealing increases in land and building taxes, taxes on motorized and non-motorized vehicles, and local community taxes. ${ }^{33,34}$

\footnotetext{
${ }^{33}$ Appendix Table A.1 explores effects on housing and assets. On average 43 percent of the sample lives in urban areas and even though exposure increases migration, school construction does not increase the likelihood of living in urban areas. They do appear to move to more valuable and larger housing. Row 2 shows an increase of 2.8 percent in the monthly rent equivalent payments if women are exposed, and a smaller and insignificant effect if males are exposed. Exposure increases floor area by 1.2-1.5 square meters (row 3) and utility usage by 5.1 to 8.5 percent (row 4). To approximate for household wealth, row 5 studies the impact of school construction on an asset index that is a principal component analysis of household ownership of the following durable goods: ownership of motorcycle, car, home phone, computer/laptop, television, gold/jewelry, refrigerator, water heater, LPG gas tube, boat, motorized boat, and air conditioner. The program leads to a 3-4 percent increase in the index if men or women are exposed. Aggregating all five housing and asset outcomes into an index confirms broad increases for men and women.

${ }^{34}$ We also explore the effects of exposure to school construction on the first generation's utilization of government welfare programs. Susenas 2016 collects data on four national programs that aim to reduce poverty and inequality. Ex-ante it is unclear if increased take-up of welfare programs reflects higher needs due to increased poverty or whether it is indicative of increased awareness of existing programs. As shown in Appendix Table A.4, we see few changes to any of the individual government programs or to the welfare program index in the last row.
} 


\subsection{Long-run impacts on nutrition and health}

There exists a strong correlation between education and health, although research estimating a causal relationship finds mixed evidence. ${ }^{35}$ Table 5 (health outcomes) together with Appendix Tables A.2 (nutrition) and A.3 (health investment) show three components of health impacts in response to school construction. Appendix Tables A.2 finds increases in food intake, particularly for women exposed to the program. Overall calories increase by 1.8 percent for women while the effect for men is smaller and not significant. Patterns are similar for consumption of protein, fats, and carbohydrates with respective increases of 1.8, 2.3, and 1.7 percent when women are exposed to the program, and smaller increases for men. We are unable to answer definitively (although Table 5 examines self-reported health outcomes) whether these nutrition changes for women are health improving as additional protein is likely to be beneficial for individuals in developing countries, but additional fats can be indicative of a worsening diet. ${ }^{36}$

A natural follow-up question is whether increases in nutrition and health investments result in improved health. Table 5 reveals that overall such improvements are not observed. While we see increases in not reporting a health complaint in the last month (row 1) and the number of days uninterrupted by health complaints (row 2), neither are statistically significant.

\footnotetext{
${ }^{35}$ For example, Lleras-Muney (2005) finds positive effects of education on mortality in the U.S., while Clark and Royer (2013), Malamud, Mitrut, and Pop-Eleches (2018), and Meghir, Palme, and Simeonova (2018) find no effects of education on mortality in the U.K., Romania, and Sweden, respectively. Furthermore, Baird at al. (2016) show that improved health through deworming treatment at primary schools in Kenya significantly increases education, as well as later-life labor market outcomes.

${ }^{36}$ Appendix Table A.3 shows that health expenditures increase by 7.1 percent for exposed men and 5.5 percent for women, but only the men's coefficient is significant. The effects are large for investments in preventative health, including medical check-ups, family planning, and immunizations, which increase by 19-24 percent if the woman or man is exposed to school construction. We see large increases in expenditures for family planning, including contraceptives and consultations, of 32 and 23 percent for men and women, respectively. On the curative side, households with either the man or woman exposed are 4.8-7.5 percent more likely to use a private instead of public hospital, which generally provide higher quality and more expensive health care. Finally, there is an increase of 14 percent in health insurance expenditures if women are exposed to the program. Taken together, the health investment index shows broad increases for exposed men and women, with an improvement in health investments of 0.13 standard deviations when an additional two schools are built in the individual's birth district.
} 
Considering severe health complaints only, we observe a 0.5 percentage point decrease in reports from exposed men. The aggregated health index in row 4 shows an improvement in health outcomes for men exposed to school construction but is insignificant for exposed women.

\subsection{Long-run marriage and fertility effects}

Evidence estimating the causal relationship between education and demographic outcomes has generally been mixed and nuanced, and this appears to be the case in our setting as well. ${ }^{37}$ Table 6 explores marriage and fertility outcomes for those exposed to the program in the 1970s. On average, women marry almost five years younger than men (row 1), but there is no effect of exposure to school construction on the age of first marriage. Coefficients are small and statistically insignificant. In rows 2 to 9 we explore if the program changed the types of spouses that men and women exposed to the program marry. Rows 2, 3 and 4 reveal that both men and women marry partners with higher levels of education and literacy. This is perhaps unsurprising given that the average education levels in regions with additional schools has increased, but important nonetheless because this means that education increases for exposed individuals as well as for their spouses. This further increases average education in the household, which may play an important role for the intergenerational transmission of education, which we explore in Section 5. Results remain statistically significant after correcting for multiple hypothesis testing. As shown in rows 5, 6, and 7, we do not observe any changes in the labor market outcomes of spouses, but we do see that men and women are 0.7-0.8 percentage points more likely to have a spouse who migrated (row 8). ${ }^{38}$ We do not observe changes in spouse's health (row 9).

\footnotetext{
${ }^{37}$ Osili and Long (2008) find evidence of education reducing fertility in Nigeria. On the other hand, McCrary and Royer (2011) find only a small fertility effect but a larger effect on the quality of the marriage partner in the U.S. In the Kenyan context, education subsidies reduce women's likelihood of teenage marriage and pregnancy (Duflo, Dupas, and Kremer, 2015). Looking at a wider age range, Geruso and Royer (2018) find increased education lowers teen fertility and increases the education of the spouse, but has no impact on total completed fertility.

${ }^{38}$ Migration is defined relative to the individual's birth district and may have occurred anytime between birth and 2016, so spouses may have migrated together.
} 
We do not have complete birth histories for each woman that would allow us to measure the relationship between education and total fertility. However, we can measure impacts on the number of children aged 0-14 living in the household at the time of the survey. Exposure to school construction reduces the number of children for women. The combined marriage and fertility index (row 10) shows broad improvements for both genders: two additional schools built in a district lead to increases of 0.13 and 0.10 standard deviations for exposed men and women.

\section{Second generation effects of school construction}

Having observed large long-term effects of Indonesia's school construction program on a wide range of outcomes, including education, employment, migration, living standards, and marriage, we now investigate whether the effects extend to the next generation and affect the children of those exposed to the program. As explained in Section 3, second generation impacts are measured using the same difference-in-differences framework as first generation effects. The main explanatory variable is an interaction of the intensity of school construction in a parent's birth district with an indicator of whether the parent is young enough to have benefitted from the program. Outcomes of all children living in the parent's household are considered and age fixed effects are included to ensure comparisons take place across children of the same age.

\subsection{Second generation effects on education and wellbeing}

Table 7 shows the effect of parental exposure to school construction on their children's educational attainment. Row 1 confirms that program effects persist into the next generation. ${ }^{39}$ Children with fathers exposed to the program obtain an additional 0.10 years of school, while children with exposed mothers obtain 0.17 years more. We can reject the equality of these

\footnotetext{
${ }^{39}$ Related research explores the production function for children’s human capital (Behrman and Rosenzweig, 2002; Attanasio, Meghir, and Nix, 2017) as well as focuses on how parents or teachers respond to inequalities across children (Akresh et al., 2012, Pop-Eleches and Urquiola, 2013).
} 
coefficients. The magnitudes decrease compared to the first generation results of 0.27 and 0.23 years for men and women, but are still economically meaningful. In the next subsection, we explore potential channels through which the effects persist into the next generation.

Unlike the first generation education results, no effects are observed on children for primary school completion rates (row 2) because by 2016 primary school has become nearly universal. ${ }^{40}$ There are large effects on completing lower and upper secondary for children whose parents are exposed to school construction, with the effect for exposed mothers being statistically larger than for exposed fathers. Also, unlike the first generation education results, increases in educational attainment now extend to tertiary education completion rates. Children with exposed mothers are 0.8 percentage points more likely to complete tertiary education, compared to a 0.4 percentage point increase for children with exposed fathers. An increase of the mean number of schools in a mother's birth district leads to a 25 percent increase in the likelihood her child completes tertiary education, relative to average tertiary education levels.

To account for the fact that some second generation children may still be attending school, we study the effects on age-for-grade (row 6), loosely defined as an indicator variable for whether the child is on track to complete the appropriate grades on time. ${ }^{41}$ Results confirm that having parents exposed to school construction increases the likelihood of being on track by 1.1 percentage points if the father is exposed and 1.8 percentage points if the mother is exposed.

All of the education results for mothers remain statistically significant after correcting for multiple hypothesis testing, while lower secondary and tertiary completion rates for children

\footnotetext{
${ }^{40}$ UNICEF statistics (accessed November 19, 2018: unicef.org/infobycountry/indonesia_statistics) indicate primary school net enrollment rates in Indonesia from 2008-2012 are 98 and 100 percent for boys and girls, respectively.

${ }^{41}$ The indictor variable is zero for those who did not start school by age 7 or had to repeat one or more grades before completing upper secondary education, which is compulsory in Indonesia. The indicator variable is one for those who have already completed upper secondary school or are on track to do so in a timely manner.
} 
when the father is exposed are no longer statistically significant. We aggregate the six outcomes into a second generation education index, and it shows broad increases for children with parents exposed to school construction. An increase of two additional schools built in the father or mother's birth district increases their children's educational attainment by 0.06 or 0.11 standard deviations, respectively, relative to parents who are not exposed to the program. ${ }^{42}$

\subsection{Heterogeneity of second generation results by gender and grade}

We next explore two dimensions of heterogeneity in the second generation education results.

First, we examine if school construction had different second generation effects at different grade

levels. Second, we examine, within a household, if paternal or maternal exposure to school construction had differential impacts on their children and if those impacts differed by whether the child is a son or daughter.

In Figure 3, we estimate the likelihood of a second generation child completing at least a certain number of years of school. We explore the effects depending on whether the father or mother is exposed to school construction and whether their child is a son or daughter. Results highlight that effects are small and indistinguishable from zero during primary school. Consistent with Table 7, for all other grades, exposure to school construction by mothers has a larger effect than fathers on their children’s education. For grades in lower secondary, upper secondary, and tertiary, we observe effects that are significantly different from zero for daughters when either

\footnotetext{
${ }^{42}$ Having observed increases in educational attainment for the children whose parents were exposed to the program, Appendix Table A.5 explores effects on the children's employment and self-reported health. Rows 1 and 2 examine their likelihood of being employed. We consider it welfare improving for a child not to be employed so we define these variables as the number of days and hours not engaged in work. For a child of an exposed father, we see slight reductions in days and hours worked but no effect if the mother is exposed. None of these results remain statistically significant after correcting for multiple hypothesis testing. Rows 3, 4, and 5 study second generation health effects. Children whose mothers were exposed show no effects on their health. Children whose fathers were exposed report worse health outcomes. We are unable to determine if these children are less healthy or whether their better educated parents have an understanding of health that makes them more likely to report their child as ill. Aggregating these employment and health indicators into a second generation wellbeing index shows no effect for children whose fathers are exposed and shows a positive impact if the child's mother is exposed.
} 
their mother or father is exposed to school construction. Effect sizes for second generation daughters are approximately of the same magnitude as those of the first generation's men exposed to the program (see Figure 2 for this comparison). Effect sizes are largest for daughters when the mother is exposed to the program and lowest for sons when the father is exposed. While we cannot statistically distinguish the results by gender of the parent or child when examining each grade separately, in Table 8 we investigate this issue in more detail.

Table 8 examines if the impact of parental exposure within a household varies when controlling for the partner's exposure and if those impacts differ by whether the child is a son or daughter. We face several challenges with our identification strategy that focuses on young (born 1968-1972) and old (born 1957-1962) cohorts. For a household to be included in the regression, we need both the father and mother to be in these specific birth cohorts. ${ }^{43}$ Given this selected sample, we observe that for these households the impact of mother's exposure to school construction has a much larger effect on the child than the father's exposure. An additional school built in the mother's birth district raises her child's education by 0.16 years; there is no effect if the father is exposed. In column 2, we address this selection issue by expanding the range of birth cohorts included in the regressions, now including all individuals born between 1950 and 1980. All birth cohorts born after 1968 could be exposed to the school construction that began in 1973. Both parents no longer need to be part of the young and old cohorts as previously defined. The sample size expands to 246,466 second generation children with parents in this extended cohort range. Results are consistent, with mother's exposure to school construction increasing her child's education more than father’s exposure. We can reject the equality of coefficients in both the restricted (column 1) and extended birth cohort samples (column 2).

\footnotetext{
${ }^{43}$ With this additional sample restriction, there are only 44,105 second generation children in the regression, a loss of almost two-thirds of the sample from the 120,838 children in the regressions in Table 7.
} 
We explore if parental exposure has different effects for sons and daughters. Panel A studies all children, Panel B sons, and Panel C daughters. Results for sons and daughters show consistently larger education effects for the second generation child if the mother is exposed to school construction, and in all cases, mother exposure is statistically significant. Focusing on the extended cohort sample (column 2), we can reject the equality of the mother and father exposure coefficients in the case of daughters but not sons. The benefit to daughters is three times larger if their mother rather than their father is exposed to school construction.

\subsection{Channels for intergenerational persistence of education}

In Tables 9 and 10, we perform mediation analyses to understand the mechanisms linking first and second generation outcomes. Column 1 in each table repeats the effects of parent exposure on children's years of schooling. Subsequent Table 9 columns add indexes from Figure 1 as control variables that may be mediators through which parental exposure manifests itself. Subsequent Table 10 columns add characteristics about the spouse as potential mediating factors.

Column 2 in Table 9 shows that adding the father's work and migration index leads to an 18 percent reduction of the effect of father's exposure, but the effect remains large at 0.08 additional years of school. Controlling for the mother's work and migration index barely affects the coefficient on mother's exposure. This is not surprising as we find few labor market effects for women in response to school construction. A 23 percent drop occurs for women when we control for their living standards index (column 3), in line with Section 4.3 showing large increases in expenditure for women exposed to school construction. Despite this drop, children still get an additional 0.13 years of education even if we hold expenditure constant. Columns 4 and 5 control for the index of taxes and housing/assets. Point estimates remain the same as when we control for living standards. In columns 6, 7, and 8, we include controls for the parent's 
nutrition, health investments, and health outcomes. We do not find support for these factors as potential mechanisms mediating the effect of parent's exposure to school construction.

In column 9 we control for the individual's marriage index, which includes spouse characteristics as well as age of first marriage and household size. For fathers, this leads to a sizable 42 percent drop in the direct effect of exposure on their children's education. This is consistent with the previous subsection's findings showing that mothers, whose characteristics are now partly controlled for, have a large impact on the intergenerational transmission of education. On the contrary, when we control for the marriage market index for exposed mothers, the drop is only 19 percent and the direct effect of exposure on children's schooling remains.

In the last column, we include all indexes as control variables. The exposure coefficients drop to 0.055 for fathers exposed and 0.111 for mothers exposed. Holding constant many of the variables that are affected by school construction explains 43 and 34 percent of the effect on second generation's years of schooling and the rest appears to be a more direct effect. There are many channels that we do not observe in the data through which these effects could manifest themselves, for example through increased encouragement to attend school or study. We cannot distinguish between these channels, but based on this table, we conclude there remains a direct effect from parents to their children that is not explained by changes in own characteristics.

Given the marriage index’s importance as a mediating variable in Table 9, revealing that marriage is an important mechanism explaining the intergenerational transfer of education, we explore further the importance of specific spousal characteristics in Table 10. The effect of father's exposure on second generation's years of schooling drops significantly once we control for the mother's education variables. Controlling for whether she completes primary school reduces the estimate by more than half and makes it indistinguishable from zero. Controlling for 
the wife's years of schooling or literacy leads to reductions of 29 and 49 percent, respectively. This reaffirms the importance of mother's educational background for her children's education, as we saw in Section 5.2 and Table 8. When the mother is exposed, controlling for the father's education variables leads to a smaller but still sizable drop of 25-32 percent of the main effect.

Spouse's labor market outcomes explain part of the effect of exposure on children's years of schooling, especially whether the spouse has a formal sector job or works in a non-agricultural sector. The coefficient for father's exposure falls by 28-30 percent when controlling for the mother's sectoral choice, and the mother's coefficient drops by 23-25 percent. Controlling for spouse's migration status or health does not significantly alter the program exposure coefficients.

Finally, in column 10, we control for all spouse characteristics, and the main effect for fathers falls to 0.020 -almost an 80 percent drop-and becomes indistinguishable from zero. This reveals that for fathers most of the effect of exposure works through his spouse's characteristics. For mothers, the coefficient drops by almost half, but remains statistically significant and economically meaningful at 0.091 additional years of schooling. Overall, these analyses provide evidence that especially for men, marriage market outcomes and spouse characteristics are an important channel through which exposure to school construction increases children's schooling.

\subsection{Selection of second generation individuals}

There are two data issues that are relevant for our second generation analysis and the selection of individuals in the regressions. First, there is a tradeoff between the selection of which individuals remain in a household, and are therefore in the survey, and what age they need to be to finish higher levels of school. Focusing only on younger children ages 0-15 reduces the selection bias as few of them leave the household by that age, but they are not old enough to complete higher levels of schooling, which are important to study since primary school is nearly universal in 
2016. As we include older children, they have time to complete higher schooling levels but a larger percentage of them leave the household. In the second generation analyses thus far, we include all children who still live with their parents, regardless of age. We, of course, include child age fixed effects. We illustrate the rationale of not imposing age restrictions in Appendix Figure A.3. In the top panel, we show the exposure coefficient for second generation children's years of schooling when we limit the analysis to individuals under a certain age, and on the xaxis we vary the upper-bound to the ages included. Given that lower levels of education are universal in 2016, we do not find an effect if we for children age 0-15. As we move to higher ages, the increase in sample size is shown in the bottom panel, and effect sizes increase as individuals are given time to complete their education.

Second, Susenas 2016, like most household surveys, only includes information on individuals currently residing in a given household but not on family members living elsewhere. For second generation children who are no longer living with their parents, perhaps because they started a new household, we cannot link them to their biological parents, and we do not know if the parents of these children are exposed to the program. For this reason, all second generation analyses thus far are based on those still living with their parents. We next explore the robustness of the results under various assumptions about the children who have left the household.

To do this, we conduct three bounding analyses. First, we estimate extreme bounds in which we assume all non-co-resident children have parents who are or are not exposed (Manski, 1990). The intuition behind this is to re-assign individuals living apart from their parents back into the sample. ${ }^{44}$ In Appendix Table A.7, we compare our baseline estimate for the second

\footnotetext{
${ }^{44}$ For children living away from their parents, we must assume the parent's birth district and birth year to determine the parent's exposure. As we have no other information, we assume the parent's and child's birth district are the same. To test this assumption's robustness, we estimate Table 7 using a child's instead of parent's birth district, and results are consistent. In the main regressions, we include birth year fixed effects, but it is harder to predict parent's
} 
generation's years of schooling (Table 7, row 1) to the first bounding strategy. Including all individuals in the survey under age 40 in the second generation regression increases the sample from 120,838 and 105,523 in the father's and mother's regressions to 644,675 observations. In regressions measuring the effect of father's exposure on his child's years of schooling, results are no longer statistically significant with these extreme bounds in which we assume all non-coresident children are born to non-exposed fathers (column 2) and then all non-co-resident children are born to exposed fathers (column 3). The education effects for second generation children whose mothers are exposed to school construction remain statistically significant despite these extreme assumptions. Assuming all non-co-resident children are born to mothers who are not exposed yields an effect of 0.05 more years of school, while assuming all non-coresident children are born to mothers who are exposed yields an effect of $0.03 .{ }^{45}$

Aside from the extreme assumption that parents of non-co-resident children are either all exposed or all not exposed, we also likely add too many individuals to the regression. The second bounding exercise attempts to address these issues. The bounding regressions for second generation children should not include children born to parents who are not in the old (19571962) or young (1968-1972) cohorts. To improve our bounds, we use the Indonesia Family Life Survey (IFLS) that does well in tracking individuals over time and matching parents to children

birth year given only a child's age, so we now include an indicator variable for whether the parent is in the young cohort. Estimating Table 7 replacing birth year dummies with a young cohort dummy yield consistent results. Further, to minimize the probability of including individuals who are unlikely to be children of a parent in our young or old cohorts, we impose an age restriction of 40 that would imply parents in the old cohort were at least 14-19 years old at the time of birth. We also maintain the exposure status of children who still live with their parents. ${ }^{45}$ The effects using these extreme bounds are smaller than our Table 7 estimates. This is to be expected if parental exposure to school construction leads to an increase in their children's years of schooling. The reason for this is that the children we add to our sample are a combination of children whose parents are and are not exposed. In the case we assume all parents are exposed, some of these children actually had non-exposed parents and thus no increased educational attainment due to their parent's exposure, but we incorrectly assign them to the group of exposed parents, which biases the estimates downwards. Similarly, if we assume all parents are not exposed, some of these children actually had exposed parents so increased educational attainment, but we incorrectly assign them to the group of unexposed parents, which again leads to a downward bias of the estimates. 
who moved away. ${ }^{46}$ We use these data to obtain the fraction of children at each age born to old and young cohort parents among all children no longer living with their parents. We use these IFLS-based fractions to randomly assign at each age non-co-resident children in the Susenas data to either old or young cohort parents and exclude the rest from the regression ${ }^{47}$ We simulate this randomization assignment procedure 1,000 times and estimate the second generation years of schooling regression. Appendix Figure A.4 shows the distribution of coefficients from these 1,000 repetitions for father's and mother's exposure to school construction. Effect sizes for father's exposure on their children's years of schooling range from 0.011 to 0.047 at the $5^{\text {th }}$ and $95^{\text {th }}$ percentiles with a median coefficient of 0.028 . Effect sizes for mother's exposure are larger, ranging between 0.018 and 0.065 with a median coefficient of $0.043 .{ }^{48}$

Third, we repeat the second generation analysis directly using the IFLS. The last three columns in Appendix Table A.7 show estimates for all children, only those living with their parents, and those who moved away. Those living with their parents provides the closest comparison to our Susenas sample. Across all three samples, we find no statistically significant effect for fathers exposed to school construction. The estimated effect of mother's exposure is 0.539 in the sample of children still living with their parents compared to 0.300 in the sample of all children. This suggests an effect only 56 percent as large if we are unable to include non-coresident children in the analysis. Scaling down our estimate of mother's exposure in column 1 by this magnitude yields an estimated effect of 0.094 additional years of schooling, which is still economically meaningful and substantially higher than the coefficients in Appendix Figure A.4.

\footnotetext{
${ }^{46} 87.8$ percent of individuals surveyed in the 1993 first wave were tracked or deceased by the last wave in 2014/5. We match 91 percent of children in the last wave's household roster to their co-resident or non-co-resident parents. ${ }^{47}$ Results are consistent if we use the fraction of non-co-resident children at each age and gender who are born to old and young cohort parents and use these age-gender based fractions to draw random samples in the Susenas data.

${ }^{48}$ Coefficients for father's exposure are statistically significant at the 10, 5, and 1 percent levels in 47,27 , and 5 percent of the regressions. Coefficients for mother's exposure are statistically significant more often. In 63, 42, and 13 percent of the regressions, the coefficients are statistically significant at the 10, 5, and 1 percent levels.
} 


\section{Threats to identification and robustness checks}

\subsection{Possible general equilibrium effects}

The analysis presented so far exploits variation across regions and birth cohorts to identify partial equilibrium effects of school construction. This raises the concern that general equilibrium effects might undo the direct program effect (Heckman, Lochner, and Taber, 1998). In our situation, if school construction increases the young cohort's education in high intensity regions, this could affect individuals who are not exposed to school construction (either older cohorts or young cohorts in low intensity regions). Depending on how these general equilibrium effects work, they could potentially bias our results leading to either an over- or under-estimate of the true effect. Whether the general equilibrium effects have a negative or positive effect depends on the substitutability or complementarity between old and young cohorts.

School construction leads to more educated young workers. If those workers are substitutes for the older cohorts in the labor market, then this increase could drive down wages for the older cohorts who are competing with them for jobs in those locations. If that happens, then the effects we observe in our specification for improved living standards for the young relative to the old cohort would be over-estimating the true effect of the program. Duflo (2004) provides evidence that these general equilibrium effects might have occurred in Indonesia, although the magnitudes of the bias appear to be rather small. Focusing on the instrumental variables specification she estimates, she finds that an increase of 10 percentage points in the share of primary school graduates leads to a 2.9-3.8 percent decrease in wages for the old cohorts. Given we observe an increase of only 2.6 percentage points in the likelihood of completing primary school for men, the subsequent old cohort wage decreases would be less than 1 percent. Adjusting our estimates by that magnitude does not significantly alter our results. 
In addition, if we adjust by this magnitude the cost-benefit calculations discussed in Section 7, it would not affect our overall interpretation of the benefits of school construction. ${ }^{49}$

Alternatively, if the young cohorts are complements for the old cohorts (for instance, because they start more businesses and hire older cohort individuals or because they spend more money on goods and services produced by the older cohorts), then the older cohorts benefit by having more educated younger cohorts in their location. If these effects dominate the general equilibrium impact, we would underestimate the true effect.

Unfortunately, the data do not allow us to distinguish between these competing stories of complementarity and substitutability among old and young cohorts. Furthermore, the evidence on general equilibrium effects from developed countries (Angrist, 1995; Crepon et al., 2013; Bianchi, 2018) is unlikely to be helpful in understanding the developing country, Indonesian context over the past four decades. In our case, we can show there are no systematic trend breaks when comparing the old cohort with an even older cohort. While this is certainly not definitive, the results for household expenditures in Appendix Figure A.5 highlight that there is not a differential trend when comparing the old cohort (ages 12-17 in 1974) with an even older cohort (ages 18-24 in 1974). If general equilibrium effects negatively impact older cohorts, we would expect to see the oldest cohorts be the worst off but that is not what we observe.

\subsection{Robustness checks}

In this subsection, we present a set of specification checks highlighting the robustness of the main results. Our identification assumption is that the change in outcomes across birth cohorts in

\footnotetext{
${ }^{49}$ Recent research on large-scale government education investments in India finds that the general equilibrium effects could be larger, with these effects working to depress the returns to education by 32 percent (Khanna, 2018). However, the analysis of the Indian policy highlights that skilled workers are worse off while unskilled workers benefit. In the Indonesian context, this evidence about unskilled workers benefiting implies older cohorts who were more likely to be lower educated and unskilled would have benefited from these general equilibrium effects, thus providing suggestive evidence that our difference-in-differences specification underestimates the true effect.
} 
regions that built many schools would have been the same in the absence of the program as the change across birth cohorts in regions that built fewer schools. However, educational patterns between birth cohorts could vary systematically across regions because of issues such as mean reversion. To test this assumption, we estimate placebo regressions comparing old cohorts (ages $12-17$ in 1974) and even older cohorts (ages 18-24 in 1974). If the assumption is correct, then any change in outcomes between cohorts in these groups, both of whom were not exposed to the program, should not differ across regions. Appendix Figure A.6 presents the results from estimating placebo regressions for each of the indexes for every family of outcomes (similar to Figure 1). Across the first generation outcomes for females and males, the placebo regressions show no statistically significant effects, which is suggestive evidence that the main difference-indifferences results are not driven by a failure of the identification assumption. ${ }^{50}$

In the main results, we follow Duflo (2001) by using a conservative definition of school exposure. Individuals in the young cohort (born 1968-1972) benefit from full exposure to the program, while those in the old cohort (born 1957-1962) did not benefit from school construction at all. However, there are other birth cohorts, partly exposed and not exposed, that could be included in the analysis. Appendix Table A.8 examines how the regression for first generation years of schooling in Table 1 changes with alternative birth cohort definitions. Column 1 repeats the original results and columns 2-5 add additional birth cohorts. In column 2, we add older cohorts born between 1950 and 1956 who were not exposed to school construction. Column 3 adds individuals born between 1963 and 1967 who would have been primary-school aged in 1974 (ages 7-11) when the schools were built. To be conservative, we assume all of these cohorts

\footnotetext{
${ }^{50}$ We do observe a statistically significant effect in the placebo regressions for second generation education. This implies there may have been a time trend across regions that could have influenced educational outcomes for second generation children. However, if children whose parents born 1957-1962 are experiencing more education compared with children whose parents are born 1950-1956, then that likely means we are underestimating the true effect.
} 
were not exposed, although in Appendix Figure A.2, it appears children ages 7-8 probably did benefit from the program. Column 4 includes children born between 1973 and 1980 who were born during and just after the schools were built and so they would have received full exposure to the program. ${ }^{51}$ Finally, in column 5, we include all individuals born between 1950 and 1980. Results using the different sample definitions are consistent, showing that exposure to school construction increased years of schooling for men and women. In Appendix Figure A.7, we use the extended cohort definition (all individuals born between 1950 and 1980) and re-estimate the effect of school construction on indexes for families of outcomes (as in Figure 1). Results are consistent, showing large positive benefits for men and women exposed to school construction.

All regressions using expenditure data are estimated with an inverse hyperbolic sine transformation (IHS). While this is typical to analyze expenditures, in Appendix Table A.9, we show robustness checks using alternative transformations. Columns 1-4 show total expenditures, columns 5-8 education expenditures. Columns 1 and 5 repeat the results from rows 1 and 5 of Table 3 using an IHS transformation. Column 2 uses the log of nominal expenditures; column 3 uses nominal expenditures. Results are similar in both cases. In column 4, we estimate household per capita instead of total expenditure (using an IHS transformation) to capture potential changes in household structure that could be correlated with exposure. Effects are smaller, but results show that male and female exposure still increases household expenditures. Results for education expenditures using a log transformation (column 6) or nominal values (column 7) leads to different results due to the large number of zeroes for education expenditures (over 20,000 observations are dropped) and because education data are heavily skewed.

\footnotetext{
${ }^{51}$ These Indonesian primary schools were initially expected to last for 20 years so the last cohort that could have gained the full six years of primary school education and completed primary schooling by 1993 would have been born in 1980. Note that with these 1973-1980 cohorts, parents could potentially have moved to give their children access to these schools, although results are consistent with the earlier ones.
} 
Finally, we re-estimate the results measuring the effect of school construction on outcome indexes (as in Figure 1) using alternative control variables. Appendix Figure A.8 shows results excluding the interaction of birth year dummies and water and sanitation programs. The magnitudes and levels of statistical significance are consistent in this case.

\section{Rate of return and fiscal impacts of school construction}

Regression results highlight the many beneficial impacts for individuals exposed to school construction and for the intergenerational transmission of those benefits. We conduct a costbenefit analysis to evaluate whether school construction was cost efficient for the Indonesian government. ${ }^{52}$ Most analyses compare a program's costs and overall welfare benefits of that program for the affected population. We also do that. However, what is unique in our case is our ability to use detailed data on tax revenues collected by the government to also measure if these increases in government taxes collected offset the government's costs of building the schools.

We start by measuring the costs of school construction. Total costs include the initial investment to build the schools and train the teachers plus recurring commitments to pay teacher salaries each year. The key point for the costs is that there were large and upfront costs at the beginning of the program in 1973 and then subsequent smaller, but annual costs every year for teacher salaries. School construction cost approximately 782 million 2016 US dollars, around 1.5 percent of the 1973 Indonesian GDP (Duflo, 2001). Schools were expected to recruit three teachers and accommodate 120 students. Using estimates by Daroesman (1971), training three teachers across 61,800 schools would have cost the government 11.7 million in 2016 dollars. ${ }^{53}$

\footnotetext{
${ }^{52}$ Appendix $\mathrm{C}$ discusses in more detail the assumptions made in our cost-benefit analysis and the specific parameters we include in the model.

${ }^{53}$ On the cost side, we adjust a number of relevant parameters in our model to see how the cost-benefit calculations respond, including the discount rate, the number of years the school is expected to last, the number of teachers and students per school, whether there is real growth in a teacher's salary, and the level of recurrent school administrative costs in addition to teachers' salaries.
} 
We focus on two main benefits. The first are taxes paid directly to the government. We have information on taxes each household paid, and we have information on total household expenditures that we use to estimate the ten percent Value-Added-Tax (VAT) the government would have collected on those purchases. The second benefit is improvements in the first generation's overall living standards. ${ }^{54}$ The key issue for the benefits is that the government or individual earns the benefits each year and they accrue over many years, but these benefits do not start until long after the schools are built. ${ }^{55}$

We develop a cost-benefit model to include these costs and benefits in the specific years they would have been realized and then trace out the arc of when discounted benefits and costs offset. Table 11 summarizes results and highlights how different assumptions about parameters influence the level of costs and benefits, impact the year when benefits outweigh costs, and affect the internal rate of return (IRR). Column 1 is a less conservative approach. ${ }^{56}$ Using these parameters yields a total cost (school building, teacher training, and recurrent teacher salaries) of 2.55 billion in 2016 USD and a total tax benefit (direct taxes paid plus VAT taxes collected) of 9.00 billion in 2016 USD. This gives a net benefit of 6.56 billion, a 1998 breakeven year, and an IRR of 10.5 percent. Moving beyond government taxes and focusing on the program's impact on improving living standards raises net benefits to 59.24 billion with an IRR of 20.7 percent.

From this baseline, we modify parameters and trace how those changes impact costs and benefits. Column 2 includes real salary growth for teachers and costs are higher and net benefits

\footnotetext{
${ }^{54}$ Second generation individuals receive more education due to school construction, which could lead to increased future tax payments and improved living standards. However, we do not include these effects in our model.

${ }^{55}$ On the benefit side, we adjust various parameters to test the sensitivity of our results. These include the discount rate, the number of years the school is expected to last, the age individuals start paying taxes, an individual's life expectancy, the Indonesian economy's growth rate, and the lifetime curvature in mean taxes paid at each age.

${ }^{56}$ In this column, we assume a 5 percent discount rate, no real growth in teachers' salary, no adjustment for the lifetime curvature of an individual's earnings (and subsequent taxes), no real growth in GDP per capita, 120 students per classroom, schools last 20 years, individuals start paying taxes after age 18, school administration costs 1.25 times teachers' salaries, 3 teachers per school, and an individual's life expectancy is 60 .
} 
smaller. Column 3 adjusts for the lifetime curvature in an individual's tax payments that peak around ages 40-50. Tax and living standards benefits are smaller. Column 4 adjusts for real GDP per capita growth of 3.25 percent. Taxes and living standards are measured in 2016, but those had real growth prior to 2016 and this adjustment reduces net benefits. Column 5 represents what we believe is a reasonable baseline case. We maintain previous parameter values but increase the mean number of students per school from 120 to 180 (30 per grade), which is closer to what happened when these schools were built. Tax benefits are higher than costs with an IRR of 8.1 percent, while living standards are substantially larger than costs with an IRR of 16.8 percent. Column 6 assumes that schools last 40 years. Original 1973 government plans called for schools to last 20 years, but since most schools are still in operation now, this is a reasonable assumption. Benefits increase because there are more cohorts exposed to the program, but there are more years to pay teacher salaries so costs also increases. Net benefits are higher, but the IRR only increases slightly because of the timing of when additional costs are incurred. Column 7 increases the age when individuals start paying taxes; column 8 raises the recurrent cost multiplier from 1.25 to 1.5. Both changes have minor impacts on net benefits. Column 9 adjusts the number of teachers per school from three to six, and this substantially raises costs. Lastly, column 10 adjusts life expectancy, which increased significantly over this period. Tax and living standards benefits substantially outweigh costs. ${ }^{57}$

Appendix Figure A.9 graphs the discounted net tax and living standards benefits over time and highlights the breakeven years for when benefits outweigh school construction costs. Using the parameters from columns 5 and 10 in Table 11, we show two highly realistic scenarios

\footnotetext{
${ }^{57}$ To have a situation in which tax benefits do not outweigh costs using the column 10 parameters, it is necessary to adjust parameters so that recurrent costs must be greater than 1.9, the number of students must be less than 145 , or the discount rate must be larger than 5.7 percent. However, net living standards benefits still remain positive until the following more drastic parameter adjustment of increasing the discount rate to larger than 12 percent is made.
} 
that the government would have faced. Overall net tax benefits are not that different across the two scenarios (5.42 and 7.76 billion), but the breakeven year in the scenario with more teachers, higher recurrent costs, and a longer school lifetime is later. The net benefit to improved living standards is also much higher the longer the schools last (133.5 billion) and the improvement to the population's welfare offsets the program costs by 2003.

Across a range of different parameter estimates, school construction leads to increased government tax revenues that offset school construction costs in most cases within 40 years. Even larger net benefits are observed when we include the population's improved living standards with net benefits ranging from 40 to 136 billion USD. Internal rates of return range from 13-21 percent and benefits outweigh costs within 17-30 years after the schools are built.

\section{Conclusion}

This paper studies the long-term and intergenerational effects of one of the largest school construction programs in history. We use a difference-in-differences estimation strategy exploiting variation across birth cohorts and regions in the number of schools built. We combine this with nationally representative data from Indonesia that contain information on a wide range of outcomes related to education, employment, migration, living standards, taxes, and marriage outcomes. We find that men and women exposed to the program attain more education, with men’s education effects continuing beyond primary school. As adults, men exposed to school construction are more likely to be formal workers and work in a non-agricultural sector. Both men and women exposed to the program are more likely to have migrated from their birth district, although evidence points to increases in local migration within the province. Households in which either parent is exposed to school construction have higher living standards, more 
assets, and pay more government taxes. Exposure to school construction substantially alters marriage market outcomes with spouses being more educated and more likely to have migrated.

These benefits are transmitted to the next generation. Children with fathers or mothers who are exposed to the school construction program obtain more education. Significant effects are observed at all levels of schooling beyond primary school, but the largest impacts are seen in tertiary education with effect sizes indicating a 20 to 25 percent increase in the likelihood of the second generation child completing university. These second generation effects are significantly larger if the mother, as opposed to the father, is exposed to the program, with additional benefits accruing to daughters. We perform a detailed mediation analysis to explore the mechanisms that drive the intergenerational transmission of schooling. Marriage market outcomes appears to a play a crucial role, particularly whether the spouse has completed primary school, is literate, works in the formal sector, or works outside of agriculture.

Our cost benefit analysis highlights that under all reasonable assumptions school construction pays for itself in terms of additional expected government tax revenues, not to mention the additional benefits of improved living standards. Furthermore, given the observed intergenerational transmission of education, the likely long-run benefits are vast. To gain additional insight into the intergenerational transmission of education, we perform an exploratory analysis calculating the intergenerational elasticity (IGE) of education between children and parents. In policy circles, especially in developing countries, there is considerable debate about the optimal amount of intergenerational mobility. High mobility suggests equality of opportunity whereby a parent's outcome does not mechanically determine the child's, but it is critical to understand the mechanisms driving that intergenerational correlation (see Black and Devereux, 2011 and Mazumder, 2015 for a discussion of this literature). Low mobility that is due to 
differential access to schooling suggests that public policy can play a role in equalizing opportunities. Comparing the IGE across high and low program intensity areas and between young and old cohorts in our Indonesian data, we find there is an increase in mobility for children whose parents are exposed to school construction, highlighting the realized benefits of this government education policy. The broader societal impacts and changes in intergenerational transmission of human capital warrant further research. 


\section{References}

Ajayi, Kehinde F. and Phillip H. Ross. 2017. "The Effects of Education on Financial Outcomes: Evidence from Kenya.” Unpublished manuscript.

Akresh, Richard, Damien de Walque, and Harounan Kazianga. 2013. "Cash Transfers, Parental Investments, and Child Welfare: Evidence from a Randomized Evaluation of the Role of Conditionality” World Bank Policy Research Working Paper 6340.

Akresh, Richard, Damien de Walque, and Harounan Kazianga. 2016. “Evidence from a Randomized Evaluation of the Household Welfare Impacts of Conditional and Unconditional Cash Transfers Given to Mothers or Fathers” World Bank Policy Research Working Paper 7730.

Akresh, Richard, Emilie Bagby, Damien de Walque, and Harounan Kazianga. 2012. “Child Labor, Schooling, and Child Ability.” World Bank Policy Research Working Paper 5965.

Akresh, Richard. 2004. "School Enrollment Impacts of Non-traditional Household Structure.” IZA Discussion Paper 1379.

Akresh, Richard. 2009. "Flexibility of Household Structure: Child Fostering Decisions in Burkina Faso.” Journal of Human Resources, 44(4): 976-997.

Alderman, Harold, Jooseop Kim, Peter F. Orazem. 2003. “Design, Evaluation, and Sustainability of Private Schools for the Poor: The Pakistan Urban and Rural Fellowship School Experiments.” Economics of Education Review, 22(3): 265-274.

Almond, Douglas and Janet Currie. 2011. “Human Capital Development before Age Five.” In Handbook of Labor Economics, Vol. 4B, ed. Orley Ashenfelter and David Card, 13151486. New York: Elsevier.

Andrabi, Tahir, Jishnu Das, Asim Khwaja, and Tristan Zajonc. 2011. “Do Value-Added Estimates Add Value? Accounting for Learning Dynamics.” American Economic Journal: Applied Economics, 3(3): 29-54.

Angrist, Josh. 1995. “The Economic Returns to Schooling in the West Bank and Gaza Strip.” American Economic Review, 85(5): 1065-1087.

Attanasio, Orazio, Costas Meghir, and Emily Nix. 2017. "Human Capital Development and Parental Investment in India.” NBER Working Paper 21740.

Baird, Sarah, Craig McIntosh, Berk Ozler. 2011. "Cash or Condition? Evidence from a Cash Transfer Experiment.” Quarterly Journal of Economics, 26(4): 1709-1753.

Baird, Sarah, Joan Hamory Hicks, Michael Kremer, and Edward Miguel. 2016. "Worms at Work: Long-Run Impacts of a Child Health Investment.” Quarterly Journal of Economics, 131(4): 1637-1680

Banerjee, Abhijit, Esther Duflo, Nathanael Golderg, Dean Karlan, Robert Osei, William Pariente, Jeremy Shapiro, Bram Thuysbaert, and Christopher Udry. 2015. “A 
Multifaceted Program Causes Lasting Progress for the Very Poor: Evidence from Six Countries.” Science, 348(6236): 1260799.

Barro, Robert and Xavier Sala-i-Martin. 1995. Economic Growth. New York: McGraw-Hill.

Behrman, Jere and Mark Rosenzweig. 2002. “Does Increasing Women’s Schooling Raise the Schooling of the Next Generation?” American Economic Review, 92(1): 323-334.

Behrman, Jere, Susan Parker, Petra Todd. 2011. "Do Conditional Cash Transfers for Schooling Generate Lasting Benefits? A Five-Year Followup of PROGRESA/Oportunidades.” Journal of Human Resources, 46(1): 93-122.

Benhassine, Najy, Florencia Devoto, Esther Duflo, Pascaline Dupas, Victor Pouliquen. 2015. “Turning a Shove into a Nudge? A ‘Labeled Cash Transfer’ For Education.” American Economic Journal: Economic Policy, 7(3): 86-125.

Benjamini, Yoav and Yosef Hochberg. 1995. "Controlling the False Discovery Rate: A Practical and Powerful Approach to Multiple Testing.” Journal of the Royal Statistical Society, Series B, 57(1): 289-300.

Bhalotra, Sonia and Atheendar Venkataramani. 2018. "Shadows of the Captain of the Men of Death: Health Innovation, Human Capital Investment, and Institutions.” Unpublished manuscript.

Bharati, Tushar, Seungwoo Chin, and Dawoon Jung. 2018. "Recovery from an Early Life Shock Through Improved Access to Schools: Evidence from Indonesia.” Unpublished manuscript.

Bianchi, Nicola. 2018. “The Indirect Effects of Educational Expansions: Evidence from a Large Enrollment Increase in STEM Majors.” Unpublished manuscript.

Bils, Mark and Peter J. Klenow. 2000. “Does Schooling Cause Growth?” American Economic Review, 90(5): 1160-1183.

Black, Sandra E. and Paul J. Devereux. 2011. "Recent Developments in Intergenerational Mobility.” in Handbook of Labor Economics, O. Ashenfelter and D. Card, editors, Volume 4, Elsevier: 1487-1541.

Black, Sandra E., Aline Butikofer, Paul J. Devereux, and Kjell G. Salvanes. Forthcoming. “This is Only a Test? Long-run Impacts of Prenatal Exposure to Radioactive Fallout.” Review of Economics and Statistics.

Black, Sandra E., Paul J. Devereux, and Kjell G. Salvanes. 2005. “Why the Apple Doesn’t Fall Far: Understanding Intergenerational Transmission of Human Capital.” American Economic Review, 95(1): 437-449.

Burde, Dana and Leigh Linden. 2013. "Bringing Education to Afghan Girls: A Randomized Controlled Trial of Village-Based Schools.” American Economic Journal: Applied Economics, 5(3): 27-40. 
Cameron, A. Colin, Jonah Gelbach, and Douglas L. Miller. 2011. "Robust Inference with Multiway Clustering.” Journal of Business and Economic Statistics, 29(2): 238-249.

Chetty, Raj, John Friedman, Nathaniel Hilger, Emmanuel Saez, Diane Schanzenbach, and Danny Yagan. 2011. "How Does Your Kindergarten Classroom Affect Your Earnings? Evidence from Project STAR.” Quarterly Journal of Economics, 126(4): 1593-1660.

Chevalier, Arnaud. 2004. "Parental Education and Child's Education: A Natural Experiment." IZA Discussion Paper No. 1153.

Clark, Damon and Heather Royer. 2013. "The Effect of Education on Adult Mortality and Health: Evidence from Britain.” American Economic Review, 103(6): 2087-2120.

Crepon, Bruno, Esther Duflo, Marc Gurgand, Roland Rathelot, and Philippe Zamora. 2013. "Do Labor Market Policies Have Displacement Effects: Evidence from a Clustered Randomized Experiment.” Quarterly Journal of Economics, 128(2): 531-580.

Currie, Janet and Enrico Moretti. 2003. "Mother’s Education and the Intergenerational Transmission of Human Capital: Evidence from College Openings." Quarterly Journal of Economics, 118(4): 1495-1532.

Currie, Janet. 2011. "Inequality at Birth: Some Causes and Consequences." American Economic Review, 101(3): 1-22.

Daroesman, Ruth. 1971. "Finance of Education.” Bulletin of Indonesian Economic Studies, 7(3): 61-95.

Duflo, Esther, Pascaline Dupas, and Michael Kremer. 2015. "Education, HIV, and Early Fertility: Experimental Evidence from Kenya.” American Economic Review, 105(9): 2757-2797.

Duflo, Esther, Pascaline Dupas, and Michael Kremer. 2017. "The Impact of Free Secondary Education: Experimental Evidence from Ghana.” Unpublished manuscript.

Duflo, Esther. 2001. "Schooling and Labor Market Consequences of School Construction in Indonesia: Evidence from an Unusual Policy Experiment.” American Economic Review, 91(4): 795-813.

Duflo, Esther. 2004. "The Medium Run Effects of Educational Expansion: Evidence from a Large School Construction Program in Indonesia.” Journal of Development Economics, 74(1): 163-197.

Evans, David and Muthoni Ngatia. 2018. "School Costs, Short-Run Participation, and Long-Run Outcomes: Evidence from Kenya.” World Bank Policy Research Working Paper 8421.

Fiszbein, Ariel and Norbert Schady. 2009. "Conditional Cash Transfers: Reducing Present and Future Poverty.” The World Bank, Washington, DC.

Foster, Andrew D. and Mark R. Rosenzweig. 1996. "Technical Change and Human-Capital Returns and Investments: Evidence from the Green Revolution.” American Economic Review, 86(4): 931-953. 
Garces, Eliana, Duncan Thomas, and Janet Currie. 2002. "Longer-Term Effects of Head Start.” American Economic Review, 92(4): 999-1012.

Gertler, Paul, James Heckman, Rodrigo Pinto, Arianna Zanolini, Christel Vermeersch, Susan M. Chang, Sally Grantham-McGregor. 2014. "Labor Market Returns to an Early Childhood Stimulation Intervention in Jamaica.” Science, 344(6187): 998-1001.

Geruso, Michael and Heather Royer. 2018. "The Impact of Education on Family Formation: Quasi-Experimental Evidence from the UK.” NBER Working Paper 24332.

Glewwe, Paul and Karthik Muralidharan. 2016. "Improving Education Outcomes in Developing Countries: Evidence, Knowledge Gaps, and Policy Implications.” Handbook of the Economics of Education, Volume 5. Elsevier Publisher.

Gorseline, Donald. 1932. "The Effect of Schooling upon Income. Bloomington.” University of Indiana Press.

Grossman, Gene M. and Elhanan Helpman. 1991. Innovation and Growth in the Global Economy. Cambridge, MA: MIT Press.

Handa, Sudhanshu. 2002. "Raising Primary School Enrollment in Developing Countries: The Relative Important of Supply and Demand.” Journal of Development Economics, 69(1): 103-128.

Heckman, James J., Lance Lochner, and Christopher Taber. 1998. "General Equilibrium Effects: A Study of Tuition Policy.” American Economic Review, 88(2): 381-386.

Heckman, James J., Seong Hyeok Moon, Rodrigo Pinto, Peter A. Savelyev, and Adam Yavitz. 2010. "The Rate of Return to the Highscope Perry Preschool Program.” Journal of Public Economics, 94(1-2): 114-128.

Heckman, James, John Eric Humphries, and Gregory Veramendi. 2018. "Returns to Education: The Causal Effects of Education on Earnings, Health, and Smoking." Journal of Political Economy, 126(S1): S197-S246.

Hicks, Joan, Marieke Kleemans, Nicholas Li, Edward Miguel. 2017. "Reevaluating Agricultural Productivity Gaps with Longitudinal Microdata.” NBER Working Paper 23253.

Jacob, Brian, Lars Lefgren, and David Sims. 2010. “The Persistence of Teacher-Induced Learning.” Journal of Human Resources, 45(4): 915-943.

Jensen, Robert. 2010. “The (Perceived) Returns to Education and the Demand for Schooling." Quarterly Journal of Economics, 25(2): 515-548.

Kazianga, Harounan, Dan Levy, Leigh Linden, and Matt Sloan. 2013. "The Effects of 'GirlFriendly' Schools: Evidence from the BRIGHT School Construction Program in Burkina Faso.” American Economic Journal: Applied Economics, 5(3): 41-62.

Khanna, Gaurav. 2018. "Large-scale Education Reform in General Equilibrium: Regression Discontinuity Evidence from India.” Unpublished manuscript. 
Kleemans, Marieke and Jeremy Magruder. 2018. "Labour Market Responses to Immigration: Evidence from Internal Migration Driven by Weather Shocks.” Economic Journal, 128(613): 2032-2065.

Klenow, Peter and Andres Rodriguez-Clare. 1997. "The Neoclassical Revival in Growth Economics: Has it Gone Too Far?” NBER Macroeconomics Annual, 12: 73-103.

Klenow, Peter and Andres Rodriguez-Clare. 2005. "Externalities and Growth.” Handbook of Economic Growth, Volume 1A. Edited by Philippe Aghion and Steven N. Durlauf. Elsevier publishing.

Kling, Jeffrey R., Jeffrey B. Liebman, and Lawrence F. Katz. 2007. "Experimental Analysis of Neighborhood Effects.” Econometrica, 75(1): 83-119.

Kremer, Michael, Edward Miguel, and Rebecca Thornton. 2009. "Incentives to Learn.” Review of Economics and Statistics, 91(3): 437-456.

Lleras-Muney, Adriana. 2005. “The Relationship Between Education and Adult Mortality in the U.S.” Review of Economic Studies, 72(1): 189-221.

Malamud, Ofer, Andreea Mitrut, and Cristian Pop-Eleches. 2018. "The Effect of Education on Mortality and Health: Evidence from a Schooling Expansion in Romania.” NBER Working Paper 24341.

Mankiw, N. Gregory, David Romer, and David N. Weil. 1992. “A Contribution to the Empirics of Economic Growth.” Quarterly Journal of Economics, 107(2): 407-437.

Manski, Charles. 1990. "Nonparametric Bounds on Treatment Effects.” American Economic Review, 80(2): 319-323.

Marazyan, Karine. 2011. "Effects of a Sibship Extension to Foster Children on Children's School Enrollment: A Sibling Rivalry Analysis for Indonesia.” Journal of Development Studies, 47(12): 497-518.

Maurin, Eric and Sandra McNally. 2008. "Vive la Revolution! Long-Term Educational Returns of 1968 to the Angry Students.” Journal of Labor Economics, 26(1): 1-33.

Mazumder, Bhashkar. 2015. "Estimating the Intergenerational Elasticity and Rank Association in the US: Overcoming the Current Limitations of Tax Data.” Research in Labor Economics, 43: 83-129

McCrary, Justin and Heather Royer. 2011. "The Effect of Female Education on Fertility and Infant Health: Evidence from School Entry Policies Using Exact Date of Birth.” American Economic Review, 101(1): 158-195.

McEwan, Patrick. 2015. "Improving Learning in Primary Schools of Developing Countries: A Meta-Analysis of Randomized Experiments.” Review of Educational Research, 85(3): 353-394. 
Meghir, Costas, Marten Palme, and Emilia Simeonova. 2018. "Education and Mortality: Evidence from a Social Experiment.” American Economic Journal: Applied Economics, 10(2): 234-256.

Muralidharan, Karthik and Nishith Prakash. 2017. "Cycling to School: Increasing Secondary School Enrollment for Girls in India.” American Economic Journal: Applied Economics, 9(3): 321-350.

Oreopoulos, Philip, Marianne Page, and Ann Huff Stevens. 2008. "The Intergenerational Effects of Worker Displacement.” Journal of Labor Economics, 26(3): 455-483.

Osili, Una Okonkwo and Bridget Terry Long. 2008. "Does Female Schooling Reduce Fertility? Evidence from Nigeria.” Journal of Development Economics, 87(1): 57-75.

Oster, Emily and Rebecca Thornton. 2011. "Menstruation, Sanitary Products, and School Attendance: Evidence from a Randomized Evaluation.” American Economic Journal: Applied Economics, 3(1): 91-100.

Parker, Susan and Tom Vogl. 2017. "Do Conditional Cash Transfers Improve Economic Outcomes in the Next Generation? Evidence from Mexico.” NBER Working Paper 24303.

Pop-Eleches, Cristian and Miguel Urquiola. 2013. "Going to a Better School: Effects and Behavioral Responses.” American Economic Review, 103(4): 1289-1324.

Ravallion, Martin. 1988. “INPRES and Inequality: A Distributional Perspective on the Centre’s Regional Disbursements” Bulletin of Indonesian Economic Studies, 24(3): 53-71.

Rizky, Mayang, Daniel Suryadarma, and Asep Suryahadi. 2018. "Effect of Growing-Up Poor on Labour Market Outcome: Evidence from Indonesia.” Unpublished manuscript.

Romer, Paul. 1990. “Endogenous Technological Change.” Journal of Political Economy, 89(5): S71-S102.

Thomas, Duncan, Firman Witoelar, Elizabeth Frankenberg, Bondan Sikoki, John Strauss, Cecep Sumantri, and Wayan Suriastini. 2012. "Cutting the Costs of Attrition: Results from the Indonesia Family Life Survey.” Journal of Development Economics, 98(1): 108-123.

Walsh, J. R. 1935. “Capital Concept Applied to Man.” Quarterly Journal of Economics, 49(2): 255-285.

World Bank. 1989. “Indonesia Basic Education Study.” World Bank Report 7841-IND. Washington, D.C. Population and Human Resources Operations Division.

Young, Alwyn. 1994. "Lessons from the East Asian NICs: A Contrarian View.” European Economic Review, 38(3-4): 964-973.

Young, Alwyn. 1995. “The Tyranny of Numbers: Confronting the Statistical Realities of the East Asian Growth Experience.” Quarterly Journal of Economics, 110(3): 641-680.

Young, Alwyn. 2013. “Inequality, the Urban-Rural Gap, and Migration.” Quarterly Journal of Economics, 128(4): 1727-1785. 


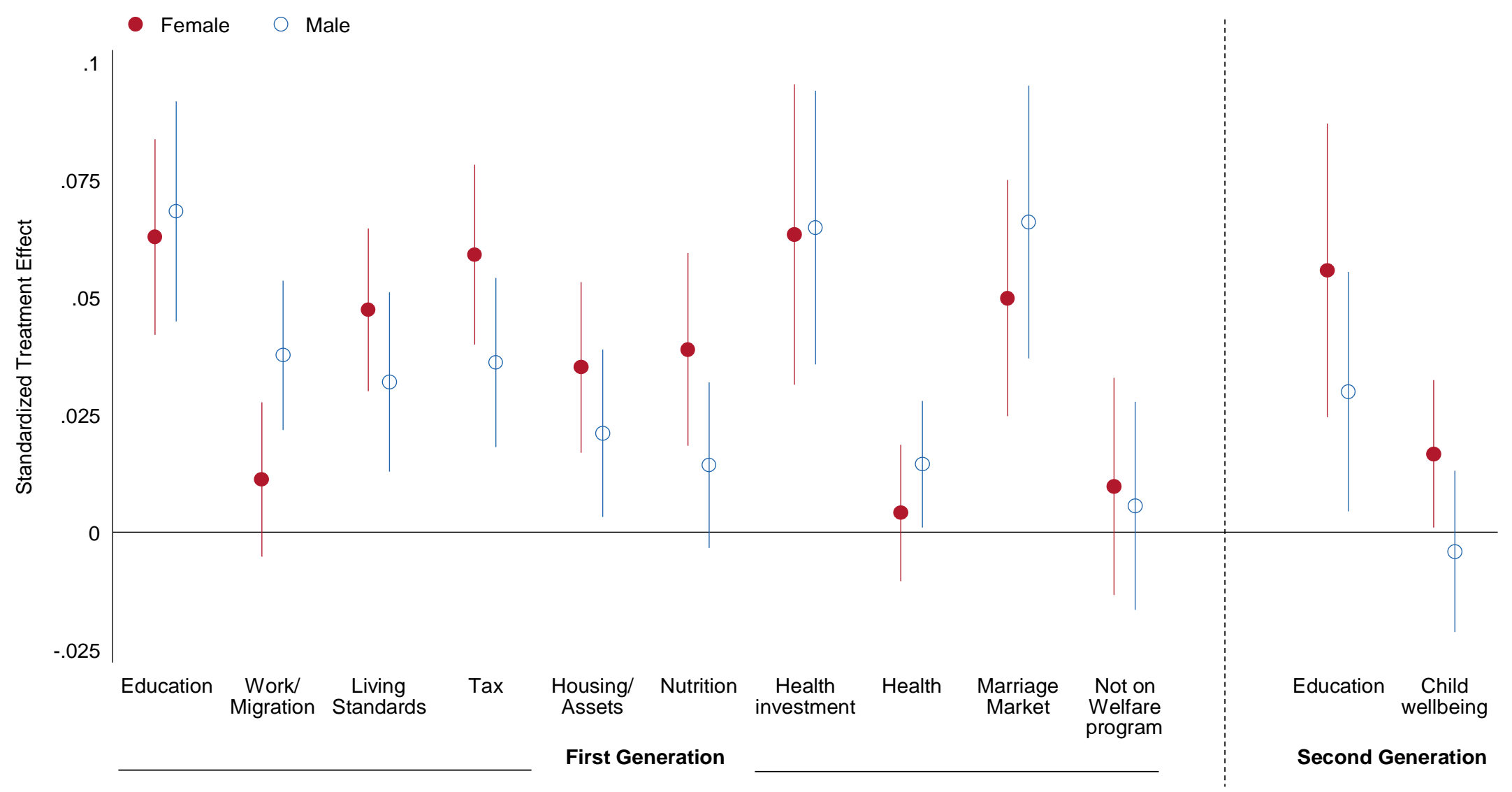

Figure 1. Effect of school construction on indexes of long-run outcomes

Notes: Following Kling, Liebman, and Katz (2007), we define indexes for families of outcomes by defining a Z-score for each outcome relative to the control group (defined in this case as the old cohort in low program intensity regions). Then, we average the Z-scores across all outcomes in the same family to get an index, such as "Marriage Market”. Following Banerjee et al. (2015) to get standardized treatment effects, we then standardize the Kling indexes relative to the mean and standard deviation of the control group. Each dot in the figure represents the coefficient of the interaction of the number of INPRES schools built between 1973 and 1979 in one's birth district and a dummy for being born between 1968 and 1972. Solid lines represent 95\% confidence intervals. The individual outcomes making up the index for each family are listed in Tables 1-7 and Appendix Tables A.1 to A.5. 
- Female $\circ$ Male

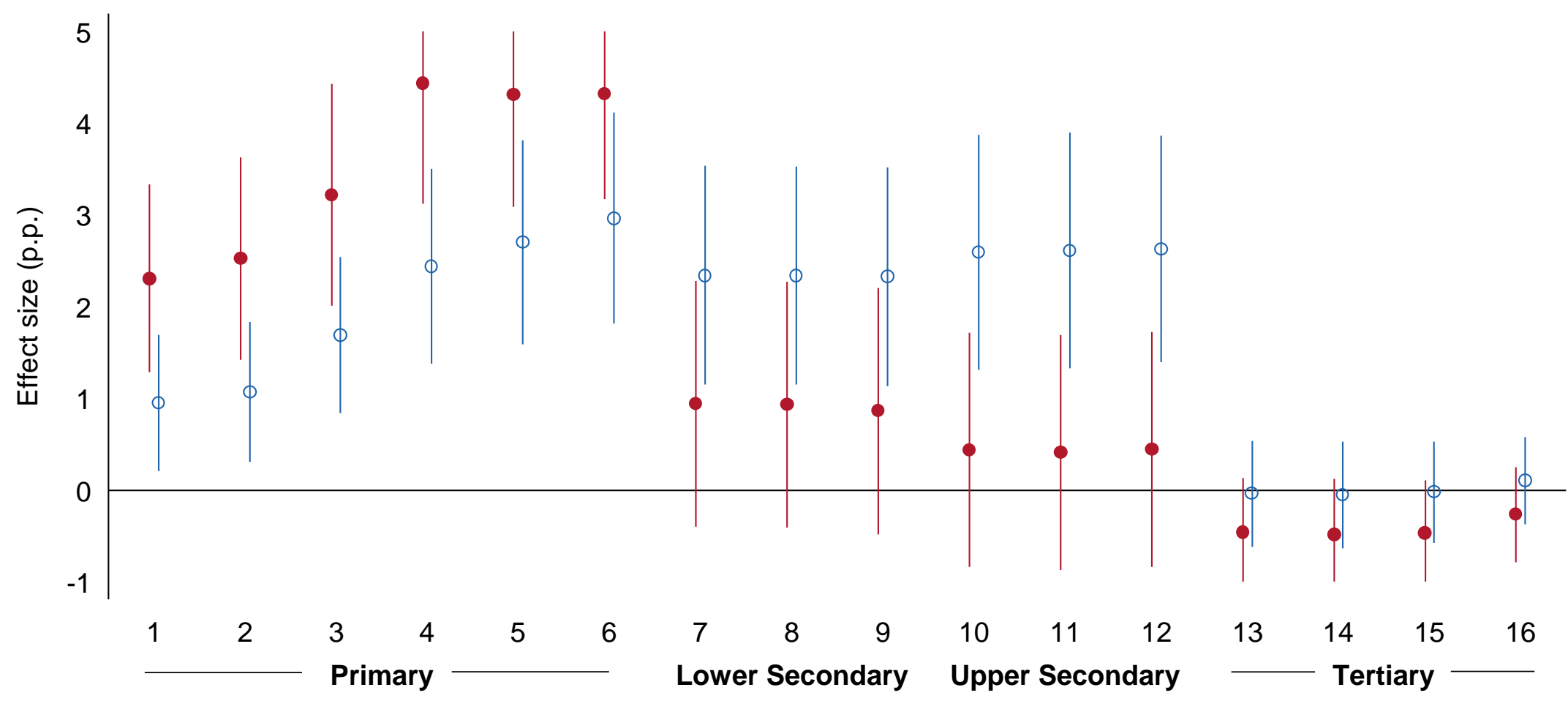

Figure 2. Effect of school construction on the probability of first generation individual attending at least $\boldsymbol{n}$-years of schooling

Notes: Effect size measures the impact of one additional school constructed per 1,000 children on the probability of completing at least $n$-years of schooling in percentage points. We show estimated regression coefficients and their respective $95 \%$ confidence intervals. 
- Mother on Daughter

$\diamond$ Mother on Son

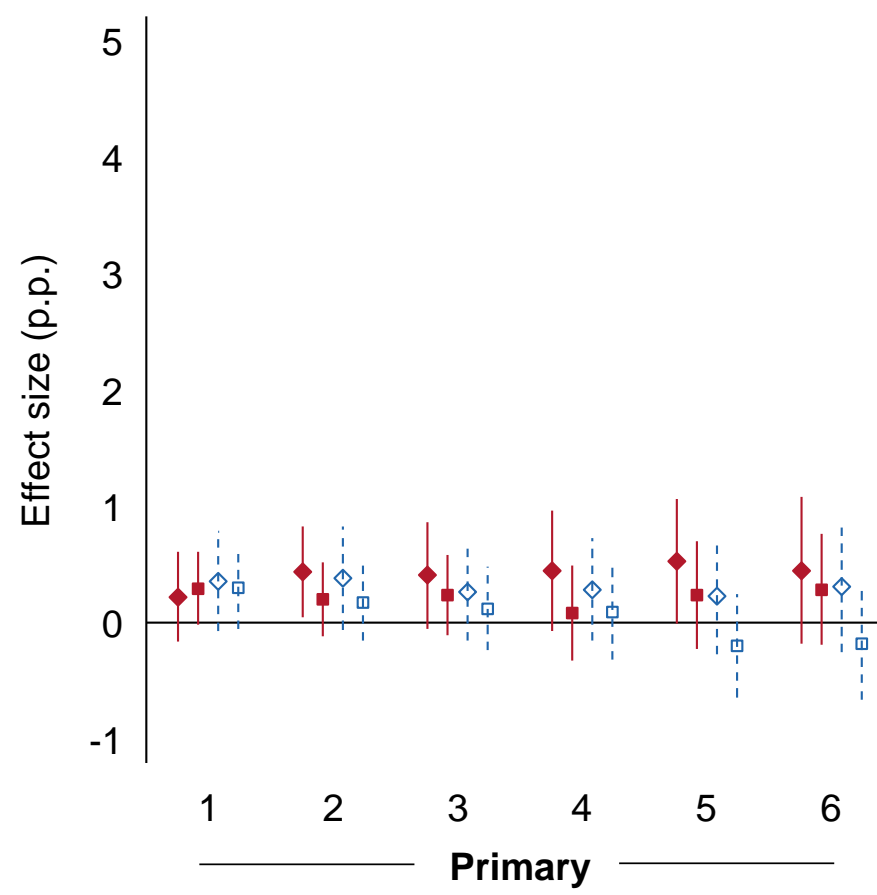

- Father on Daughter

- Father on Son

Figure 3 Effect of school construction on the probability of second generation individual attending at least $\boldsymbol{n}$-years of schooling

Notes: Effect size measures the impact of one additional school constructed per 1,000 children in the mother's or father's birth district on the probability of a second generation individual (daughter or son) attending at least $n$-years of schooling in percentage points. Each dot represents a coefficient in a separate regression. We show estimated regression coefficients and their respective $95 \%$ confidence intervals. 
Table 1. Effect of school construction on first generation's education

\begin{tabular}{|c|c|c|c|c|c|}
\hline \multirow[b]{2}{*}{ Outcome } & \multirow[b]{2}{*}{ Description } & \multicolumn{2}{|c|}{ Mean / SD } & \multicolumn{2}{|c|}{$\begin{array}{l}\text { Effect of Program } \\
\text { Exposure on: }\end{array}$} \\
\hline & & Men & Women & Men & Women \\
\hline $\begin{array}{l}\text { Years of } \\
\text { schooling }\end{array}$ & $\begin{array}{l}\text { Based on highest education level and grade attended. } \\
\text { Standard durations of study are assumed; grade } \\
\text { retentions are not counted }\end{array}$ & $\begin{array}{c}8.022 \\
(4.230)\end{array}$ & $\begin{array}{c}7.105 \\
(4.215)\end{array}$ & $\begin{array}{l}0.268 * * * \\
(0.047) \\
{[0.000]}\end{array}$ & $\begin{array}{l}0.234 * * * \\
(0.042) \\
{[0.000]}\end{array}$ \\
\hline $\begin{array}{l}\text { Completed } \\
\text { Primary }\end{array}$ & $\begin{array}{l}\text { Indicator defined as } 1 \text { if highest diploma completed is } \\
\text { higher than or equal to Primary }\end{array}$ & $\begin{array}{c}0.813 \\
(0.390)\end{array}$ & $\begin{array}{c}0.727 \\
(0.446)\end{array}$ & $\begin{array}{l}0.026 * * * \\
(0.006) \\
{[0.000]}\end{array}$ & $\begin{array}{l}0.041 * * * \\
(0.006) \\
{[0.000]}\end{array}$ \\
\hline $\begin{array}{l}\text { Completed Lower } \\
\text { Secondary }\end{array}$ & $\begin{array}{l}\text { Indictor defined as } 1 \text { if highest diploma completed is } \\
\text { higher than or equal to Lower Secondary }\end{array}$ & $\begin{array}{c}0.385 \\
(0.487)\end{array}$ & $\begin{array}{c}0.312 \\
(0.463)\end{array}$ & $\begin{array}{l}0.023 * * * \\
(0.006) \\
{[0.000]}\end{array}$ & $\begin{array}{l}0.008 \\
(0.007) \\
{[0.422]}\end{array}$ \\
\hline $\begin{array}{l}\text { Completed Upper } \\
\text { Secondary }\end{array}$ & $\begin{array}{l}\text { Indicator defined as } 1 \text { if highest diploma completed is } \\
\text { higher than or equal to Upper Secondary }\end{array}$ & $\begin{array}{c}0.338 \\
(0.473)\end{array}$ & $\begin{array}{c}0.261 \\
(0.439)\end{array}$ & $\begin{array}{l}0.026 * * * \\
(0.006) \\
{[0.000]}\end{array}$ & $\begin{array}{l}0.005 \\
(0.006) \\
{[0.422]}\end{array}$ \\
\hline $\begin{array}{l}\text { Completed } \\
\text { Tertiary }\end{array}$ & $\begin{array}{l}\text { Indicator defined as } 1 \text { if highest diploma completed is } \\
\text { higher than or equal to Tertiary }\end{array}$ & $\begin{array}{c}0.095 \\
(0.293)\end{array}$ & $\begin{array}{c}0.077 \\
(0.267)\end{array}$ & $\begin{array}{l}-0.001 \\
(0.003) \\
{[0.741]}\end{array}$ & $\begin{array}{l}-0.003 \\
(0.003) \\
{[0.422]}\end{array}$ \\
\hline Literate & Literacy is a binary outcome and is self-reported & $\begin{array}{c}0.953 \\
(0.212)\end{array}$ & $\begin{array}{c}0.909 \\
(0.287)\end{array}$ & $\begin{array}{l}0.015^{* * *} \\
(0.004) \\
{[0.001]}\end{array}$ & $\begin{array}{l}0.033 * * * \\
(0.006) \\
{[0.000]}\end{array}$ \\
\hline Education index & $\begin{array}{l}\text { Aggregates all } 6 \text { outcomes and standardizes it to the } \\
\text { mean of the old cohort in low-program regions. } \\
\text { Effects are interpreted as standard deviation changes } \\
\text { from the mean. }\end{array}$ & & & $\begin{array}{c}0.068 * * * \\
(0.012)\end{array}$ & $\begin{array}{c}0.063 * * * \\
(0.011)\end{array}$ \\
\hline
\end{tabular}

constructed in region of birth. All regressions control for district of birth and cohort of birth fixed effects, children's population and enrollment in 1971, and water and sanitation program intensities that vary by region of birth interacted with birth year dummies. Robust standard errors clustered at region of birth are shown in parentheses. Stars denote statistical significance at 1, 5, and 10\% levels based on unadjusted p-values. FDR q-values are computed over all 6 outcomes and are shown in square brackets. FDR qvalues indicate the probability of false positives among significant tests. There are 72,367 and 71,423 observations in the men's and women's regressions, respectively. 
Table 2. Effect of school construction on first generation's work and migration

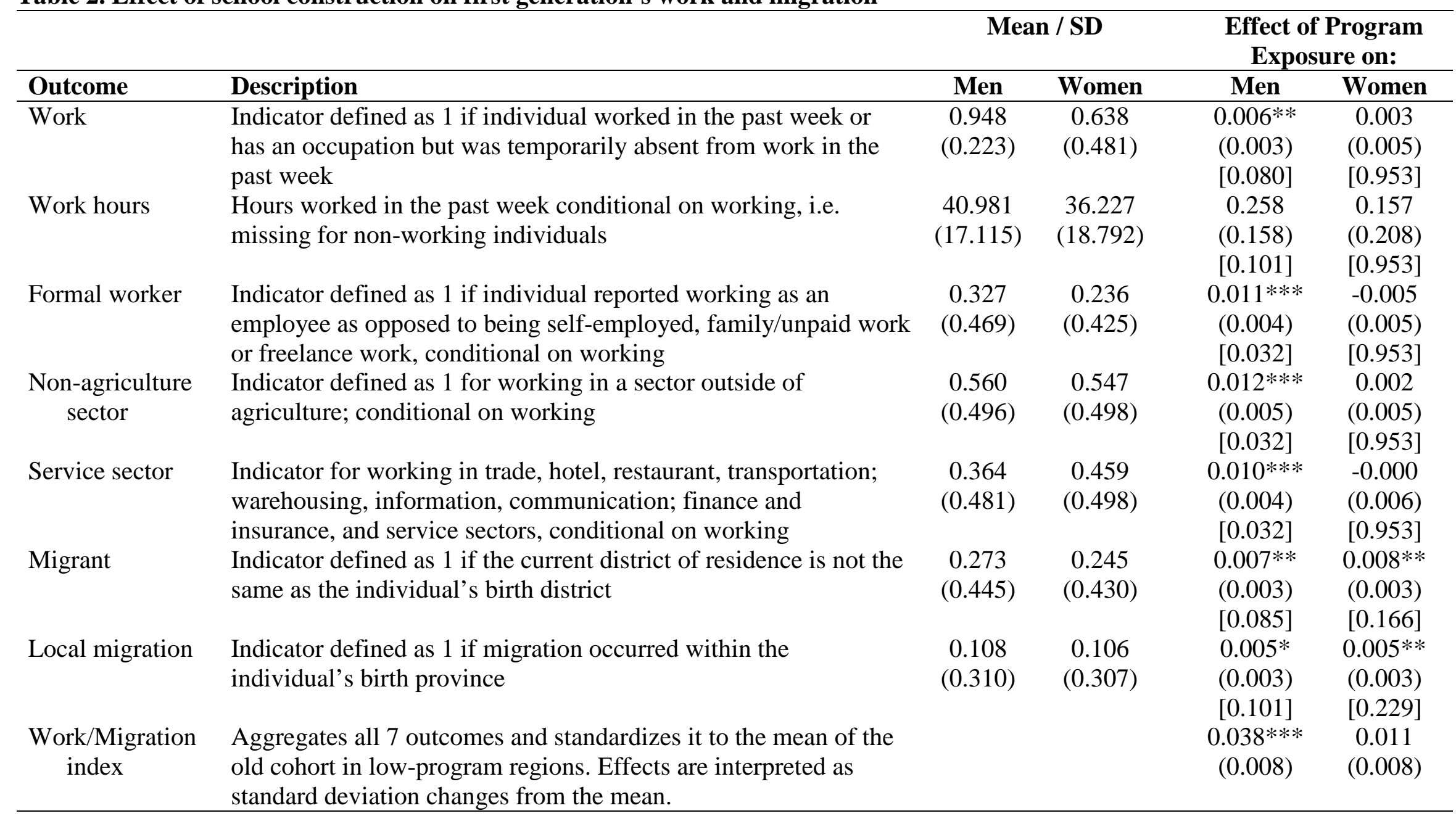

Notes: Effect of program exposure are the regression coefficients of young cohort dummy interacted with the number of schools constructed in region of birth. All regressions control for district of birth and cohort of birth fixed effects, children's population and enrollment in 1971, and water and sanitation program intensities that vary by region of birth interacted with birth year dummies. Robust standard errors clustered at region of birth are shown in parentheses. Stars denote statistical significance at 1, 5, and 10\% levels based on unadjusted p-values. FDR q-values are computed over all 7 outcomes and are shown in square brackets. FDR q-values indicate the probability of false positives among significant tests. There are 72,367 observations for men and 68,574 conditional on working. There are 71,423 observations for women and 45,560 conditional on working. 
Table 3. Effect of school construction on first generation's living standards

\begin{tabular}{|c|c|c|c|c|c|}
\hline \multirow[b]{2}{*}{ Outcome } & \multirow[b]{2}{*}{ Description } & \multicolumn{2}{|c|}{ Mean / SD } & \multicolumn{2}{|c|}{$\begin{array}{l}\text { Effect of Program } \\
\text { Exposure on: }\end{array}$} \\
\hline & & Men & Women & Men & Women \\
\hline Total (Rp10k) & $\begin{array}{l}\text { Household's average monthly expenditure; means are reported } \\
\text { in 10,000 Indonesian Rupiah (IDR) increments. Total } \\
\text { expenditures are made up of food and non-food expenditures. }\end{array}$ & $\begin{array}{c}391.649 \\
(352.495)\end{array}$ & $\begin{array}{c}375.616 \\
(343.823)\end{array}$ & $\begin{array}{l}0.021^{* * *} \\
(0.007) \\
{[0.010]}\end{array}$ & $\begin{array}{l}0.032 * * * \\
(0.007) \\
{[0.000]}\end{array}$ \\
\hline Food (Rp10k) & & $\begin{array}{c}194.443 \\
(120.447)\end{array}$ & $\begin{array}{c}184.222 \\
(121.110)\end{array}$ & $\begin{array}{l}0.014 * * \\
(0.007) \\
{[0.036]}\end{array}$ & $\begin{array}{l}0.028 * * * \\
(0.007) \\
{[0.000]}\end{array}$ \\
\hline $\begin{array}{l}\text { Non-food } \\
\text { (Rp10k) }\end{array}$ & & $\begin{array}{l}197.206 \\
(271.884)\end{array}$ & $\begin{array}{c}191.393 \\
(261.111)\end{array}$ & $\begin{array}{l}0.027 * * * \\
(0.008) \\
{[0.004]}\end{array}$ & $\begin{array}{l}0.039 * * * \\
(0.008) \\
{[0.000]}\end{array}$ \\
\hline Non-food/Total & Share of non-food over total expenditures. & $\begin{array}{c}44.592 \\
(13.376)\end{array}$ & $\begin{array}{c}45.144 \\
(13.751)\end{array}$ & $\begin{array}{c}0.287 * * * \\
(0.110) \\
{[0.024]}\end{array}$ & $\begin{array}{l}0.237 * * * \\
(0.102) \\
{[0.021]}\end{array}$ \\
\hline $\begin{array}{l}\text { Education } \\
\qquad \text { (Rp10k) }\end{array}$ & $\begin{array}{l}\text { Education expenditures fall under non-food expenditures and } \\
\text { include admission, tuition, extracurricular fees, textbooks, } \\
\text { stationery, and tutoring }\end{array}$ & $\begin{array}{c}13.971 \\
(33.167)\end{array}$ & $\begin{array}{c}12.202 \\
(30.346)\end{array}$ & $\begin{array}{c}0.160 * * \\
(0.064) \\
{[0.024]}\end{array}$ & $\begin{array}{c}0.193 * * \\
(0.076) \\
{[0.011]}\end{array}$ \\
\hline $\begin{array}{l}\text { Living standards } \\
\text { index }\end{array}$ & $\begin{array}{l}\text { Aggregates total, food, and education expenditures and } \\
\text { excludes non-food expenditure and non-food/total ratio to } \\
\text { avoid collinearity in the regression. Standardizes it to the } \\
\text { mean of the old cohort in low-program regions. Effects are } \\
\text { interpreted as standard deviation changes from the mean. }\end{array}$ & & & $\begin{array}{c}0.032 * * * \\
(0.010)\end{array}$ & $\begin{array}{c}0.047 * * * \\
(0.009)\end{array}$ \\
\hline
\end{tabular}

Notes: Effect of program exposure are the regression coefficients of young cohort dummy interacted with the number of schools constructed in region of birth. All regressions control for district of birth and cohort of birth fixed effects, children's population and enrollment in 1971, and water and sanitation program intensities that vary by region of birth interacted with birth year dummies. Robust standard errors clustered at region of birth are shown in parentheses. Stars denote statistical significance at 1, 5, and 10\% levels based on unadjusted p-values. FDR q-values are computed over all 5 outcomes and are shown in square brackets. FDR q-values indicate the probability of false positives among significant tests. There are 68,687 and 66,249 observations in the men's and women's regressions, respectively. We apply an inverse hyperbolic sine transformation to all monetary values. Estimates can be interpreted as percentage changes. 
Table 4. Effect of school construction on first generation's taxes

\begin{tabular}{|c|c|c|c|c|c|}
\hline \multirow[b]{2}{*}{ Outcome } & \multirow[b]{2}{*}{ Description } & \multicolumn{2}{|c|}{ Mean / SD } & \multicolumn{2}{|c|}{$\begin{array}{l}\text { Effect of Program } \\
\text { Exposure on: }\end{array}$} \\
\hline & & Men & Women & Men & Women \\
\hline Total (Rp10k) & $\begin{array}{l}\text { Self-reported tax expenditures include the following } \\
\text { components and "other" }\end{array}$ & $\begin{array}{c}4.749 \\
(11.433)\end{array}$ & $\begin{array}{c}4.552 \\
(10.743)\end{array}$ & $\begin{array}{l}0.078 * * * \\
(0.017) \\
{[0.000]}\end{array}$ & $\begin{array}{l}0.123 * * * \\
(0.019) \\
{[0.000]}\end{array}$ \\
\hline $\begin{array}{l}\text { Land \& building } \\
\qquad \text { (Rp10k) }\end{array}$ & Taxes on land and/or building ownership & $\begin{array}{r}0.465 \\
(2.742)\end{array}$ & $\begin{array}{r}0.506 \\
(2.446)\end{array}$ & $\begin{array}{l}0.041^{*} \\
(0.022) \\
{[0.120]}\end{array}$ & $\begin{array}{l}0.075 * * * \\
(0.021) \\
{[0.000]}\end{array}$ \\
\hline Vehicle (Rp10k) & Motorized and non-motorized vehicle license fees & $\begin{array}{r}3.610 \\
(8.076)\end{array}$ & $\begin{array}{r}3.398 \\
(7.821)\end{array}$ & $\begin{array}{l}0.154 * * * \\
(0.047) \\
{[0.003]}\end{array}$ & $\begin{array}{l}0.267 * * * \\
(0.052) \\
{[0.000]}\end{array}$ \\
\hline Local (Rp10k) & $\begin{array}{l}\text { Levies/retributions; examples include: } \\
\text { neighborhood/citizen associations, garbage, security, } \\
\text { cemetery, parking, fees }\end{array}$ & $\begin{array}{r}0.469 \\
(2.259)\end{array}$ & $\begin{array}{r}0.468 \\
(2.074)\end{array}$ & $\begin{array}{r}0.048 \\
(0.033) \\
{[0.148]}\end{array}$ & $\begin{array}{l}0.082 * * \\
(0.039) \\
{[0.036]}\end{array}$ \\
\hline Tax index & $\begin{array}{l}\text { Aggregates all } 4 \text { outcomes and standardizes it to the mean of } \\
\text { the old cohort in low-program regions. Effects are } \\
\text { interpreted as standard deviation changes from the mean. }\end{array}$ & & & $\begin{array}{l}0.036 * * * \\
(0.009)\end{array}$ & $\begin{array}{l}0.059 * * * \\
(0.010)\end{array}$ \\
\hline
\end{tabular}

Notes: Effect of program exposure are the regression coefficients of young cohort dummy interacted with the number of schools constructed in region of birth. All regressions control for district of birth and cohort of birth fixed effects, children's population and enrollment in 1971, and water and sanitation program intensities that vary by region of birth interacted with birth year dummies. Robust standard errors clustered at region of birth are shown in parentheses. Stars denote statistical significance at 1, 5, and 10\% levels based on unadjusted p-values. FDR q-values are computed over all 4 outcomes and are shown in square brackets. FDR qvalues indicate the probability of false positives among significant tests. Total taxes includes land and building, vehicle, local, and other taxes. Other taxes include vehicle citations and income taxes, which are largely voluntary and represent a small contribution to government budget. "Other” taxes represent less than 5\% of household tax expenditures. There are 68,687 and 66,249 observations in the men's and women's regressions, respectively. We apply an inverse hyperbolic sine transformation to all monetary values. Estimates can be interpreted as percentage changes. 
Table 5. Effect of school construction on first generation's health outcomes

\begin{tabular}{|c|c|c|c|c|c|}
\hline \multirow[b]{2}{*}{ Outcome } & \multirow[b]{2}{*}{ Description } & \multicolumn{2}{|c|}{ Mean / SD } & \multicolumn{2}{|c|}{$\begin{array}{l}\text { Effect of Program } \\
\text { Exposure on: }\end{array}$} \\
\hline & & Men & Women & Men & Women \\
\hline $\begin{array}{l}\text { No health } \\
\text { complaint }\end{array}$ & $\begin{array}{l}\text { Self-reported indicator defined as } 1 \text { if did not experience } \\
\text { a health complaint in the past month }\end{array}$ & $\begin{array}{c}0.690 \\
(0.463)\end{array}$ & $\begin{array}{c}0.646 \\
(0.478)\end{array}$ & $\begin{array}{c}0.004 \\
(0.004) \\
{[0.352]}\end{array}$ & $\begin{array}{c}0.003 \\
(0.004) \\
{[0.771]}\end{array}$ \\
\hline $\begin{array}{l}\text { Non-disrupted } \\
\text { days }\end{array}$ & $\begin{array}{l}\text { Self-reported number of days in the past month } \\
\text { (maximum of } 30 \text { days) that a health complaint did not } \\
\text { disrupt daily activities }\end{array}$ & $\begin{array}{l}28.851 \\
(4.012)\end{array}$ & $\begin{array}{l}28.801 \\
(4.064)\end{array}$ & $\begin{array}{c}0.042 \\
(0.028) \\
{[0.266]}\end{array}$ & $\begin{array}{c}0.027 \\
(0.033) \\
{[0.771]}\end{array}$ \\
\hline $\begin{array}{l}\text { No severe health } \\
\text { complaint }\end{array}$ & $\begin{array}{l}\text { Self-reported indicator defined as } 1 \text { if did not experience } \\
\text { a severe health complaint in the past month }\end{array}$ & $\begin{array}{c}0.951 \\
(0.216)\end{array}$ & $\begin{array}{c}0.949 \\
(0.221)\end{array}$ & $\begin{array}{c}0.005 * * * \\
(0.002) \\
{[0.025]}\end{array}$ & $\begin{array}{l}-0.001 \\
(0.002) \\
{[0.771]}\end{array}$ \\
\hline $\begin{array}{l}\text { Health outcomes } \\
\text { index }\end{array}$ & $\begin{array}{l}\text { Aggregates all } 3 \text { outcomes and standardizes it to the } \\
\text { mean of the old cohort in low-program regions. Effects } \\
\text { are interpreted as standard deviation changes from the } \\
\text { mean. }\end{array}$ & & & $\begin{array}{l}0.015 * * \\
(0.007)\end{array}$ & $\begin{array}{c}0.004 \\
(0.007)\end{array}$ \\
\hline
\end{tabular}

Notes: Effect of program exposure are the regression coefficients of young cohort dummy interacted with the number of schools constructed in region of birth. All regressions control for district of birth and cohort of birth fixed effects, children's population and enrollment in 1971, and water and sanitation program intensities that vary by region of birth interacted with birth year dummies. Robust standard errors clustered at region of birth are shown in parentheses. Stars denote statistical significance at 1, 5, and 10\% levels based on unadjusted p-values. FDR q-values are computed over all 3 outcomes and are shown in square brackets. FDR qvalues indicate the probability of false positives among significant tests. There are 72,367 and 71,423 observations in the men's and women's regressions, respectively. 
Table 6. Effect of school construction on first generation's marriage market

\begin{tabular}{|c|c|c|c|c|c|}
\hline \multirow[b]{2}{*}{ Outcome } & \multirow[b]{2}{*}{ Description } & \multicolumn{2}{|c|}{ Mean / SD } & \multicolumn{2}{|c|}{$\begin{array}{l}\text { Effect of Program } \\
\text { Exposure on: } \\
\end{array}$} \\
\hline & & Men & Women & Men & Women \\
\hline $\begin{array}{l}\text { Age of first } \\
\text { marriage }\end{array}$ & $\begin{array}{l}\text { Age of first marriage for ever-married } \\
\text { household members }\end{array}$ & $\begin{array}{l}25.219 \\
(5.022)\end{array}$ & $\begin{array}{l}20.888 \\
(4.788)\end{array}$ & $\begin{array}{c}0.058 \\
(0.053) \\
{[0.867]}\end{array}$ & $\begin{array}{c}0.050 \\
(0.059) \\
{[0.745]}\end{array}$ \\
\hline \multicolumn{6}{|c|}{ Spouse’s characteristics: } \\
\hline $\begin{array}{l}\text { Years of } \\
\text { schooling }\end{array}$ & $\begin{array}{l}\text { Based on highest education level and grade } \\
\text { attended. Standard durations of study are } \\
\text { assumed; grade retentions are not counted }\end{array}$ & $\begin{array}{r}7.635 \\
(4.081)\end{array}$ & $\begin{array}{r}7.426 \\
(4.192)\end{array}$ & $\begin{array}{c}0.180 * * * \\
(0.046) \\
{[0.001]}\end{array}$ & $\begin{array}{c}0.116 * * * \\
(0.043) \\
{[0.057]}\end{array}$ \\
\hline $\begin{array}{l}\text { Completed } \\
\text { Primary }\end{array}$ & $\begin{array}{l}\text { Indicator defined as } 1 \text { if highest diploma } \\
\text { completed is higher than or equal to Primary }\end{array}$ & $\begin{array}{r}0.797 \\
(0.402)\end{array}$ & $\begin{array}{r}0.773 \\
(0.419)\end{array}$ & $\begin{array}{c}0.038 * * * \\
(0.006) \\
{[0.000]}\end{array}$ & $\begin{array}{l}0.025 * * * \\
(0.005) \\
{[0.000]}\end{array}$ \\
\hline Literate & $\begin{array}{l}\text { Literacy is a binary outcome and is self- } \\
\text { reported }\end{array}$ & $\begin{array}{r}0.939 \\
(0.239)\end{array}$ & $\begin{array}{r}0.944 \\
(0.230)\end{array}$ & $\begin{array}{c}0.027 * * * \\
(0.006) \\
{[0.000]}\end{array}$ & $\begin{array}{l}0.016 * * * \\
(0.004) \\
{[0.001]}\end{array}$ \\
\hline Work & $\begin{array}{l}\text { Indicator defined as } 1 \text { if individual worked in } \\
\text { the past week or has an occupation but was } \\
\text { temporarily absent from work in the past } \\
\text { week }\end{array}$ & $\begin{array}{r}0.614 \\
(0.487)\end{array}$ & $\begin{array}{r}0.918 \\
(0.275)\end{array}$ & $\begin{array}{c}0.003 \\
(0.005) \\
{[0.867]}\end{array}$ & $\begin{array}{l}-0.001 \\
(0.004) \\
{[0.745]}\end{array}$ \\
\hline Formal worker & $\begin{array}{l}\text { Indicator defined as } 1 \text { if individual reported } \\
\text { working as an employee as opposed to being } \\
\text { self-employed, family/unpaid work or } \\
\text { freelance work, conditional on working }\end{array}$ & $\begin{array}{r}0.239 \\
(0.427)\end{array}$ & $\begin{array}{c}0.293 \\
(0.455)\end{array}$ & $\begin{array}{l}0.003 \\
(0.005) \\
{[0.867]}\end{array}$ & $\begin{array}{c}0.005 \\
(0.005) \\
{[0.745]}\end{array}$ \\
\hline $\begin{array}{l}\text { Non-agriculture } \\
\text { sector }\end{array}$ & $\begin{array}{l}\text { Indicator defined as } 1 \text { for working in a sector } \\
\text { outside of agriculture; conditional on } \\
\text { working }\end{array}$ & $\begin{array}{r}0.555 \\
(0.497)\end{array}$ & $\begin{array}{r}0.517 \\
(0.500)\end{array}$ & $\begin{array}{c}0.006 \\
(0.005) \\
{[0.867]}\end{array}$ & $\begin{array}{l}0.005 \\
(0.007) \\
{[0.745]}\end{array}$ \\
\hline
\end{tabular}




\begin{tabular}{|c|c|c|c|c|c|}
\hline Migrant & $\begin{array}{l}\text { Indicator defined as } 1 \text { if the current district } \\
\text { of residence is not the same as the } \\
\text { individual's birth district }\end{array}$ & $\begin{array}{c}0.260 \\
(0.439)\end{array}$ & $\begin{array}{c}0.277 \\
(0.448)\end{array}$ & $\begin{array}{l}0.007 * \\
(0.004) \\
{[0.387]}\end{array}$ & $\begin{array}{l}0.008^{* *} \\
(0.003) \\
{[0.164]}\end{array}$ \\
\hline $\begin{array}{l}\text { o health } \\
\text { complaint }\end{array}$ & $\begin{array}{l}\text { elf-reported indicator defined as } 1 \text { if did not } \\
\text { xperience a health complaint in the past } \\
\text { onth }\end{array}$ & $\begin{array}{r}0.694 \\
(0.461)\end{array}$ & $\begin{array}{r}0.646 \\
(0.478)\end{array}$ & $\begin{array}{l}-0.001 \\
(0.004) \\
{[0.867]}\end{array}$ & $\begin{array}{c}0.006 \\
(0.005) \\
{[0.745]}\end{array}$ \\
\hline \multicolumn{6}{|c|}{ Own characteristics: } \\
\hline Children 0-14 & $\begin{array}{l}\text { Number of children aged 0-14 living in the } \\
\text { household }\end{array}$ & $\begin{array}{r}0.910 \\
(1.059)\end{array}$ & $\begin{array}{r}0.559 \\
(0.868)\end{array}$ & $\begin{array}{l}-0.012 \\
(0.017) \\
{[0.867]}\end{array}$ & $\begin{array}{c}-0.035 * * \\
(0.016) \\
{[0.559]}\end{array}$ \\
\hline $\begin{array}{l}\text { Marriage market } \\
\text { index }\end{array}$ & $\begin{array}{l}\text { Aggregates all } 10 \text { outcomes and standardizes } \\
\text { it to the mean of the old cohort in low- } \\
\text { program regions. Effects are interpreted as } \\
\text { standard deviation changes from the mean. } \\
\text { For the index, we reverse the sign for } \\
\text { children } 0-14 \text { to indicate a positive outcome. }\end{array}$ & & & $\begin{array}{c}0.066 * * * \\
(0.015)\end{array}$ & $\begin{array}{l}0.050 * * * \\
(0.013)\end{array}$ \\
\hline \multicolumn{6}{|c|}{$\begin{array}{l}\text { Notes: Effect of program exposure are the regression coefficients of young cohort dummy interacted with the number of } \\
\text { schools constructed in region of birth. All regressions control for district of birth and cohort of birth fixed effects, children's } \\
\text { population and enrollment in } 1971 \text {, and water and sanitation program intensities that vary by region of birth interacted with } \\
\text { birth year dummies. Robust standard errors clustered at region of birth are shown in parentheses. Stars denote statistical } \\
\text { significance at } 1,5 \text {, and } 10 \% \text { levels based on unadjusted p-values. FDR q-values are computed over all } 10 \text { outcomes and } \\
\text { are shown in square brackets. FDR q-values indicate the probability of false positives among significant tests. Spouse's } \\
\text { characteristics are defined for household heads and spouses in the sample. The spouse's years of schooling, completed } \\
\text { primary, literacy, work, no health complaint regressions have } 64,422 \text { and } 55,468 \text { observations for men and women, } \\
\text { respectively, because it is set to missing if the spouse does not currently live in the household (divorced, widowed). The } \\
\text { spouse's formal worker and non-agriculture sector regressions have } 39,550 \text { and } 50,892 \text { observations because it is set to } \\
\text { missing if the spouse does not currently live in the household and/or does not work. The age of first marriage regression } \\
\text { has } 70,571 \text { and } 69,623 \text { observations because it is set to missing if the individual is never married. The children } 0-14 \\
\text { regression has } 68,687 \text { and } 66,249 \text { observations and corresponds to the number of household heads and spouses in Table } 3 \text {. }\end{array}$} \\
\hline
\end{tabular}


Table 7. Effect of school construction on second generation's education

\begin{tabular}{|c|c|c|c|c|c|}
\hline \multirow[b]{2}{*}{ Outcome } & \multirow[b]{2}{*}{ Description } & \multicolumn{2}{|c|}{ Mean / SD } & \multicolumn{2}{|c|}{$\begin{array}{c}\text { Effect of Program } \\
\text { Exposure by: }\end{array}$} \\
\hline & & Father & Mother & $\begin{array}{l}\text { Fathers on } \\
\text { Children }\end{array}$ & $\begin{array}{l}\text { Mothers on } \\
\text { Children }\end{array}$ \\
\hline $\begin{array}{l}\text { Years of } \\
\text { schooling }\end{array}$ & $\begin{array}{l}\text { Child's years of school based on highest education } \\
\text { level and grade attended. Standard durations of study } \\
\text { are assumed; grade retentions are not counted }\end{array}$ & $\begin{array}{c}7.967 \\
(4.340)\end{array}$ & $\begin{array}{r}8.854 \\
(4.278)\end{array}$ & $\begin{array}{c}0.097 * * * \\
(0.032) \\
{[0.014]}\end{array}$ & $\begin{array}{c}0.169 * * * \\
(0.045) \\
{[0.001]}\end{array}$ \\
\hline $\begin{array}{l}\text { Completed } \\
\text { Primary }\end{array}$ & $\begin{array}{l}\text { Indicator defined as } 1 \text { if child's highest diploma } \\
\text { completed is higher than or equal to Primary }\end{array}$ & $\begin{array}{c}0.637 \\
(0.481)\end{array}$ & $\begin{array}{r}0.728 \\
(0.445)\end{array}$ & $\begin{array}{c}0.000 \\
(0.002) \\
{[0.928]}\end{array}$ & $\begin{array}{c}0.001 \\
(0.003) \\
{[0.796]}\end{array}$ \\
\hline $\begin{array}{l}\text { Completed Lower } \\
\text { Secondary }\end{array}$ & $\begin{array}{l}\text { Indictor defined as } 1 \text { if child's highest diploma } \\
\text { completed is higher than or equal to Lower Secondary }\end{array}$ & $\begin{array}{c}0.413 \\
(0.492)\end{array}$ & $\begin{array}{r}0.504 \\
(0.500)\end{array}$ & $\begin{array}{l}0.006 * \\
(0.003) \\
{[0.171]}\end{array}$ & $\begin{array}{c}0.015 * * * \\
(0.005) \\
{[0.006]}\end{array}$ \\
\hline $\begin{array}{l}\text { Completed Upper } \\
\text { Secondary }\end{array}$ & $\begin{array}{l}\text { Indicator defined as } 1 \text { if child's highest diploma } \\
\text { completed is higher than or equal to Upper Secondary }\end{array}$ & $\begin{array}{c}0.217 \\
(0.412)\end{array}$ & $\begin{array}{r}0.300 \\
(0.458)\end{array}$ & $\begin{array}{l}0.009 * * \\
(0.004) \\
{[0.061]}\end{array}$ & $\begin{array}{c}0.014 * * * \\
(0.005) \\
{[0.013]}\end{array}$ \\
\hline $\begin{array}{l}\text { Completed } \\
\text { Tertiary }\end{array}$ & $\begin{array}{l}\text { Indicator defined as } 1 \text { if child's highest diploma } \\
\text { completed is higher than or equal to Tertiary }\end{array}$ & $\begin{array}{c}0.041 \\
(0.198)\end{array}$ & $\begin{array}{c}0.064 \\
(0.245)\end{array}$ & $\begin{array}{c}0.004^{*} \\
(0.002) \\
{[0.171]}\end{array}$ & $\begin{array}{l}0.008 * * \\
(0.003) \\
{[0.044]}\end{array}$ \\
\hline Age-for-grade & $\begin{array}{l}\text { Indicator for child starting primary school by age } 7 \\
\text { and never repeating school up to Upper Secondary }\end{array}$ & $\begin{array}{c}0.835 \\
(0.371)\end{array}$ & $\begin{array}{r}0.789 \\
(0.408)\end{array}$ & $\begin{array}{c}0.011^{* * *} \\
(0.004) \\
{[0.030]}\end{array}$ & $\begin{array}{c}0.018 * * * \\
(0.005) \\
{[0.002]}\end{array}$ \\
\hline $\begin{array}{l}\text { Second } \\
\text { generation } \\
\text { education } \\
\text { index }\end{array}$ & $\begin{array}{l}\text { Aggregates all } 6 \text { outcomes and standardizes it to the } \\
\text { mean of the old cohort in low-program regions. } \\
\text { Effects are interpreted as standard deviation changes } \\
\text { from the mean. }\end{array}$ & & & $\begin{array}{l}0.030 * * \\
(0.013)\end{array}$ & $\begin{array}{l}0.056 * * * \\
(0.016)\end{array}$ \\
\hline
\end{tabular}

Notes: Effect of program exposure are the regression coefficients of father or mother's young cohort dummy interacted with the number of schools constructed in father or mother's region of birth. All regressions control for parent's district of birth and cohort of birth fixed effects, child age fixed effects, children's population and enrollment in 1971, and water and sanitation program intensities that vary by region of birth interacted with birth year dummies. Robust standard errors clustered at parent's region of birth are shown in parentheses. Stars denote statistical significance at 1,5 , and $10 \%$ levels based on unadjusted p-values. FDR q-values are computed over all 6 outcomes and are shown in square brackets. FDR qvalues indicate the probability of false positives among significant tests. The survey restricts questions on educational attainment to individuals aged 5 and older. There are 120,838 and 105,523 observations in the father’s and mother's regressions, respectively. 
Table 8. Effect of school construction on second generation's education, by parent and child gender

\begin{tabular}{|c|c|c|}
\hline \multirow[b]{3}{*}{ Parents born between: } & \multicolumn{2}{|c|}{ Years of schooling } \\
\hline & $(1)$ & $(2)$ \\
\hline & 1957-1962 and 1968-1972 & $1950-1980$ \\
\hline \multicolumn{3}{|c|}{ Panel A: Sons and Daughters } \\
\hline \multirow[t]{2}{*}{ Father exposed } & 0.001 & $0.044 * *$ \\
\hline & $(0.038)$ & $(0.021)$ \\
\hline \multirow[t]{2}{*}{ Mother exposed } & $0.160 * * *$ & $0.118 * * *$ \\
\hline & $(0.059)$ & $(0.035)$ \\
\hline Father = Mother (p-value) & 0.046 & 0.050 \\
\hline Mean & 8.674 & 7.827 \\
\hline Observations & 44,105 & 246,466 \\
\hline \multicolumn{3}{|l|}{ Panel B: Sons Only } \\
\hline \multirow[t]{2}{*}{ Father exposed } & -0.038 & 0.042 \\
\hline & $(0.049)$ & $(0.026)$ \\
\hline \multirow[t]{2}{*}{ Mother exposed } & $0.139 * *$ & $0.094 * *$ \\
\hline & $(0.069)$ & $(0.040)$ \\
\hline Father = Mother (p-value) & 0.076 & 0.267 \\
\hline Mean & 8.575 & 7.787 \\
\hline Observations & 24,366 & 133,896 \\
\hline \multicolumn{3}{|l|}{ Panel C: Daughters Only } \\
\hline \multirow[t]{2}{*}{ Father exposed } & 0.036 & $0.046 * *$ \\
\hline & $(0.051)$ & $(0.023)$ \\
\hline \multirow[t]{2}{*}{ Mother exposed } & $0.188 * * *$ & $0.140 * * *$ \\
\hline & $(0.072)$ & $(0.038)$ \\
\hline Father = Mother (p-value) & 0.134 & 0.026 \\
\hline Mean & 8.796 & 7.875 \\
\hline Observations & 19,739 & 112,570 \\
\hline \multicolumn{3}{|c|}{$\begin{array}{l}\text { Notes: }{ }^{*} \mathrm{p}<0.10,{ }^{* *} \mathrm{p}<0.05,{ }^{* * *} \mathrm{p}<0.01 \text {. Robust standard errors in parentheses, clustered at the } \\
\text { father and mother's birth district level using the multiway clustering method of Cameron, } \\
\text { Gelbach, and Miller (2011). Father exposed indicates an interaction of the number of INPRES } \\
\text { primary schools constructed in the father's birth district and an indicator that the father is in the } \\
\text { young cohort. Mother exposed is defined similarly. Father = Mother indicates the p-value testing } \\
\text { the equality of coefficients of father exposed and mother exposed within each panel. The sample } \\
\text { in Panel A consists of both sons and daughters, Panel B sons only, and Panel C daughters only. }\end{array}$} \\
\hline
\end{tabular}


Table 9. Mediators of the effect of school construction on second generation's years of schooling

\begin{tabular}{|c|c|c|c|c|c|c|c|c|c|c|}
\hline \multirow[b]{2}{*}{ Mediator: } & \multicolumn{10}{|c|}{ Dependent Variable: Second generation's years of schooling } \\
\hline & $\begin{array}{c}(1) \\
\text { None }\end{array}$ & $\begin{array}{c}(2) \\
\text { Work/ } \\
\text { Migration }\end{array}$ & $\begin{array}{c}\text { (3) } \\
\text { Living } \\
\text { Standards } \\
\end{array}$ & $\begin{array}{c}\text { (4) } \\
\text { Tax }\end{array}$ & $\begin{array}{c}\text { (5) } \\
\text { Housing/ } \\
\text { Asset } \\
\end{array}$ & $\begin{array}{c}\text { (6) } \\
\text { Nutrition }\end{array}$ & $\begin{array}{c}\text { (7) } \\
\text { Health } \\
\text { investment }\end{array}$ & $\begin{array}{c}\text { (8) } \\
\text { Health }\end{array}$ & $\begin{array}{c}(9) \\
\text { Marriage }\end{array}$ & $\begin{array}{l}(10) \\
\text { All }\end{array}$ \\
\hline \multicolumn{11}{|l|}{ Panel A: Father } \\
\hline $\begin{array}{l}\text { Schools constructed } \\
\text { * Young cohort }\end{array}$ & $\begin{array}{c}0.097 * * * \\
(0.032)\end{array}$ & $\begin{array}{l}0.080^{* *} \\
(0.031)\end{array}$ & $\begin{array}{c}0.082 * * * \\
(0.031)\end{array}$ & $\begin{array}{c}0.084^{* * *} \\
(0.030)\end{array}$ & $\begin{array}{c}0.082 * * * \\
(0.028)\end{array}$ & $\begin{array}{c}0.095^{* * *} \\
(0.032)\end{array}$ & $\begin{array}{c}0.086 * * * \\
(0.031)\end{array}$ & $\begin{array}{c}0.096 * * * \\
(0.032)\end{array}$ & $\begin{array}{l}0.056^{*} \\
(0.028)\end{array}$ & $\begin{array}{c}0.055^{* *} \\
(0.026)\end{array}$ \\
\hline Mediator & & $\begin{array}{c}0.386 * * * \\
(0.015) \\
\end{array}$ & $\begin{array}{c}0.652 * * * \\
(0.017)\end{array}$ & $\begin{array}{c}0.539 * * * \\
(0.017) \\
\end{array}$ & $\begin{array}{c}0.772^{* * *} \\
(0.019) \\
\end{array}$ & $\begin{array}{c}0.112 * * * \\
(0.018)\end{array}$ & $\begin{array}{c}0.165^{* * *} \\
(0.013)\end{array}$ & $\begin{array}{c}0.045^{* * *} \\
(0.011) \\
\end{array}$ & $\begin{array}{c}0.616^{* * *} \\
(0.014)\end{array}$ & \\
\hline Observations & 120,838 & 120,838 & 120,838 & 120,838 & 120,838 & 120,838 & 120,838 & 120,838 & 120,838 & 120,838 \\
\hline Mean & 7.967 & 7.967 & 7.967 & 7.967 & 7.967 & 7.967 & 7.967 & 7.967 & 7.967 & 7.967 \\
\hline $\begin{array}{l}\text { Panel B: Mother } \\
\text { Schools constructed } \\
\text { * Young cohort }\end{array}$ & $\begin{array}{c}0.169 * * * \\
(0.045)\end{array}$ & $\begin{array}{c}0.166^{* * *} \\
(0.045)\end{array}$ & $\begin{array}{c}0.130 * * * \\
(0.044)\end{array}$ & $\begin{array}{c}0.138 * * * \\
(0.041)\end{array}$ & $\begin{array}{c}0.133 * * * \\
(0.039)\end{array}$ & $\begin{array}{c}0.163 * * * \\
(0.045)\end{array}$ & $\begin{array}{c}0.156^{* * *} \\
(0.043)\end{array}$ & $\begin{array}{c}0.168 * * * \\
(0.045)\end{array}$ & $\begin{array}{c}0.137 * * * \\
(0.043)\end{array}$ & $\begin{array}{c}0.111^{* * *} \\
(0.039)\end{array}$ \\
\hline Mediator & & $\begin{array}{c}0.353^{* * *} \\
(0.014)\end{array}$ & $\begin{array}{c}0.852 * * * \\
(0.019)\end{array}$ & $\begin{array}{c}0.721^{* * *} \\
(0.022)\end{array}$ & $\begin{array}{c}1.037 * * * \\
(0.019)\end{array}$ & $\begin{array}{c}0.183^{* * * *} \\
(0.020)\end{array}$ & $\begin{array}{c}0.189 * * * \\
(0.014)\end{array}$ & $\begin{array}{c}0.062 * * * \\
(0.015)\end{array}$ & $\begin{array}{c}0.602 * * * \\
(0.023)\end{array}$ & \\
\hline Observations & 105,523 & 105,523 & 105,523 & 105,523 & 105,523 & 105,523 & 105,523 & 105,523 & 105,523 & 105,523 \\
\hline Mean & 8.854 & 8.854 & 8.854 & 8.854 & 8.854 & 8.854 & 8.854 & 8.854 & 8.854 & 8.854 \\
\hline $\begin{array}{l}\text { Notes: Each column sl } \\
\text { and includes a potentia } \\
\text { are as in Table } 7 \text {. Effe } \\
\text { schools constructed in } \\
\text { fixed effects, children' }\end{array}$ & Ws a regre & $\begin{array}{l}\text { sion of the } \\
\text { riable. These }\end{array}$ & ears of schc & ( & nitation $\mathrm{p}$ & ram inten & oung coho & ummy in & $\begin{array}{l}\text { ool constru } \\
\text { in Figure } 1 \\
\text { acted with t }\end{array}$ & $\begin{array}{l}\text { ion program } \\
\text { Regressions } \\
\text { e number of } \\
\text { ts, child age }\end{array}$ \\
\hline
\end{tabular}


Table 10. Spouse's characteristics as mediators of the effect of school construction on second generation's years of schooling

\begin{tabular}{|c|c|c|c|c|c|c|c|c|c|c|}
\hline \multirow[b]{2}{*}{ Mediator: } & \multicolumn{10}{|c|}{ Dependent Variable: Second generation's years of schooling } \\
\hline & $\begin{array}{c}(1) \\
\text { None }\end{array}$ & $\begin{array}{c}(2) \\
\text { Years of } \\
\text { Schooling }\end{array}$ & $\begin{array}{c}\text { (3) } \\
\text { Completed } \\
\text { Primary }\end{array}$ & $\begin{array}{c}(4) \\
\text { Literate }\end{array}$ & $\begin{array}{c}(5) \\
\text { Work }\end{array}$ & $\begin{array}{c}\text { (6) } \\
\text { Formal } \\
\text { worker }\end{array}$ & $\begin{array}{c}\text { (7) } \\
\text { Non- } \\
\text { agriculture } \\
\text { sector }\end{array}$ & $\begin{array}{c}\text { (8) } \\
\text { Migrant }\end{array}$ & $\begin{array}{c}\text { (9) } \\
\text { No health } \\
\text { complaint }\end{array}$ & $\begin{array}{r}\text { (10) } \\
\text { All }\end{array}$ \\
\hline $\begin{array}{l}\text { Panel A: Father } \\
\text { Schools } \\
\text { constructed * } \\
\text { Young cohort }\end{array}$ & $\begin{array}{c}0.097 * * * \\
(0.032)\end{array}$ & $\begin{array}{c}0.069 * * \\
(0.030)\end{array}$ & $\begin{array}{c}0.044 \\
(0.028)\end{array}$ & $\begin{array}{l}0.049 * \\
(0.027)\end{array}$ & $\begin{array}{c}0.093 * * * \\
(0.032)\end{array}$ & $\begin{array}{l}0.068 * \\
(0.036)\end{array}$ & $\begin{array}{c}0.070 * * \\
(0.034)\end{array}$ & $\begin{array}{c}0.090 * * * \\
(0.032)\end{array}$ & $\begin{array}{c}0.092 * * * \\
(0.032)\end{array}$ & $\begin{array}{c}0.020 \\
(0.032)\end{array}$ \\
\hline Mediator & & $\begin{array}{c}0.146 * * * \\
(0.004)\end{array}$ & $\begin{array}{c}1.381 * * * \\
(0.042)\end{array}$ & $\begin{array}{c}1.798 * * * \\
(0.087)\end{array}$ & $\begin{array}{c}-0.054 * * \\
(0.024)\end{array}$ & $\begin{array}{c}0.627 * * * \\
(0.031)\end{array}$ & $\begin{array}{c}0.940 * * * \\
(0.030)\end{array}$ & $\begin{array}{c}0.330 * * * \\
(0.027)\end{array}$ & $\begin{array}{l}-0.037 * \\
(0.020)\end{array}$ & \\
\hline $\begin{array}{l}\text { Observations } \\
\text { Mean }\end{array}$ & $\begin{array}{c}120,838 \\
7.967\end{array}$ & $\begin{array}{c}116,550 \\
7.942\end{array}$ & $\begin{array}{c}116,550 \\
7.942\end{array}$ & $\begin{array}{c}116,550 \\
7.942\end{array}$ & $\begin{array}{c}116,550 \\
7.942\end{array}$ & $\begin{array}{c}70,861 \\
7.799\end{array}$ & $\begin{array}{c}70,861 \\
7.799\end{array}$ & $\begin{array}{c}116,550 \\
7.942\end{array}$ & $\begin{array}{c}116,550 \\
7.942\end{array}$ & $\begin{array}{c}70,861 \\
7.799\end{array}$ \\
\hline $\begin{array}{l}\text { Panel B: Mother } \\
\text { Schools } \\
\text { constructed * } \\
\text { Young cohort }\end{array}$ & $\begin{array}{c}0.169 * * * \\
(0.045)\end{array}$ & $\begin{array}{c}0.126 * * * \\
(0.045)\end{array}$ & $\begin{array}{c}0.115^{* * * *} \\
(0.043)\end{array}$ & $\begin{array}{c}0.125^{* * * *} \\
(0.044)\end{array}$ & $\begin{array}{c}0.153^{* * *} \\
(0.046)\end{array}$ & $\begin{array}{c}0.130 * * * \\
(0.047)\end{array}$ & $\begin{array}{c}0.126 * * * \\
(0.044)\end{array}$ & $\begin{array}{c}0.152 * * * \\
(0.046)\end{array}$ & $\begin{array}{c}0.155^{* * * *} \\
(0.046)\end{array}$ & $\begin{array}{c}0.091 * * \\
(0.043)\end{array}$ \\
\hline Mediator & & $\begin{array}{c}0.176 * * * \\
(0.004)\end{array}$ & $\begin{array}{c}1.567 * * * \\
(0.040)\end{array}$ & $\begin{array}{c}1.906 * * * \\
(0.079)\end{array}$ & $\begin{array}{c}-0.456 * * * \\
(0.063)\end{array}$ & $\begin{array}{c}0.677 * * * \\
(0.035)\end{array}$ & $\begin{array}{c}1.007 * * * \\
(0.034)\end{array}$ & $\begin{array}{c}0.452 * * * \\
(0.032)\end{array}$ & $\begin{array}{c}-0.092 * * * \\
(0.027)\end{array}$ & \\
\hline $\begin{array}{l}\text { Observations } \\
\text { Mean }\end{array}$ & $\begin{array}{c}105,523 \\
8.854\end{array}$ & $\begin{array}{c}91,384 \\
8.780\end{array}$ & $\begin{array}{c}91,384 \\
8.780\end{array}$ & $\begin{array}{c}91,384 \\
8.780\end{array}$ & $\begin{array}{c}91,384 \\
8.780\end{array}$ & $\begin{array}{c}85,036 \\
8.659\end{array}$ & $\begin{array}{c}85,036 \\
8.659\end{array}$ & $\begin{array}{c}91,384 \\
8.780\end{array}$ & $\begin{array}{c}91,384 \\
8.780\end{array}$ & $\begin{array}{c}85,036 \\
8.659\end{array}$ \\
\hline $\begin{array}{l}\text { Notes: Each colum } \\
\text { and includes a pote } \\
\text { Regressions are as } \\
\text { number of schools } \\
\text { child age fixed effe } \\
\text { with birth year dum } \\
5\end{array}$ & $\begin{array}{l}\text { I mediator } \\
\text { tructe } 7 \text {. Eff } \\
\text { thildren's }\end{array}$ & $\begin{array}{l}\text { sion of the } \\
\text { ariable. Th } \\
\text { t of progral } \\
\text { ther or mot } \\
\text { pulation ar }\end{array}$ & $\begin{array}{l}\text { ars of schoo } \\
\text { exediator } \\
\text { exposure ar } \\
\text { 's region o } \\
\text { enrollment }\end{array}$ & $\begin{array}{l}\text { ig for a sec } \\
\text { riables (as } \\
\text { he regressic } \\
\text { irth. All re } \\
1971 \text {, and }\end{array}$ & $\begin{array}{l}\text { generatio } \\
\text { icated by t } \\
\text { coefficient } \\
\text { ssions cont } \\
\text { er and sani } \\
\text { of birth are }\end{array}$ & $\begin{array}{l}\text { child on pa } \\
\text { e column h } \\
\text { of father or } \\
\text { l for paren } \\
\text { tion progra } \\
\text { hown in pa }\end{array}$ & $\begin{array}{l}\text { nt's exposu } \\
\text { ding) are s } \\
\text { other's you } \\
\text { district of } \\
\text { intensities } \\
\text { ntheses. Sta }\end{array}$ & $\begin{array}{l}\text { to the scho } \\
\text { puse's chara } \\
\text { g cohort dur } \\
\text { rth and coho } \\
\text { at vary by r } \\
\text { denote stat }\end{array}$ & $\begin{array}{l}\text { constructio } \\
\text { teristics fron } \\
\text { my interacte } \\
\text { t of birth fix } \\
\text { jion of birth } \\
\text { tical signific }\end{array}$ & $\begin{array}{l}\text { program } \\
\text { Table } 6 . \\
\text { with the } \\
\text { d effects, } \\
\text { nteracted } \\
\text { ance at } 1 \text {, }\end{array}$ \\
\hline
\end{tabular}


Table 11. Cost-benefit analysis of school construction

(1)

(2)

(3)

(4)

(5)

(6)

\section{Parameters}

Discount rate (\%)

Teachers salary growth $(\mathrm{Y} / \mathrm{N})$

Lifetime curvature $(\mathrm{Y} / \mathrm{N})$

GDP/capita growth (\%)

Students/schools

School lifetime (years)

Start paying taxes after age:

Recurrent costs/salaries multiplier

$\begin{array}{ccc}5.0 & 5.0 & 5.0 \\ \mathrm{~N} & \mathrm{Y} & \mathrm{Y} \\ \mathrm{N} & \mathrm{N} & \mathrm{Y} \\ 0 & 0 & 0 \\ 120 & 120 & 120 \\ 20 & 20 & 20 \\ 18 & 18 & 18 \\ 1.25 & 1.25 & 1.25 \\ 3 & 3 & 3 \\ 60 & 60 & 60\end{array}$

5.0
$\mathrm{Y}$
$\mathrm{Y}$
3.25
120
20
18
1.25
3
60

5.0
$\mathrm{Y}$
$\mathrm{Y}$
3.25
180
20
18
1.25
3
60

5.0
$\mathrm{Y}$
$\mathrm{Y}$
3.25
180
40
18
1.25
3
60

5.0
$\mathrm{Y}$
$\mathrm{Y}$
3.25
180
40
22
1.25
3
60

(8)

(9)

(10)

Life expectancy

$1.65 \quad 2.95 \quad 2.95 \quad 2.95 \quad 2.95$

\section{Schools construction \\ Teachers training \\ Teachers' salaries}

\section{Benefits}

Paid by cohorts born in

Collected between years

Tax receipts

Net Benefit (Benefits - Costs)

Breakeven year

Living standards

Net Benefit (Benefits - Costs)

Breakeven year

$\begin{array}{ccccc} & & & & \\ 9.00 & 9.00 & 7.32 & 6.11 & 9.16 \\ 6.56 & 5.26 & 3.58 & 2.37 & 5.42 \\ 1998 & 2001 & 2007 & 2017 & 2009 \\ 61.69 & 61.69 & 53.18 & 43.64 & 65.46 \\ 59.24 & 57.95 & 49.44 & 39.90 & 61.72 \\ 1990 & 1991 & 1992 & 1995 & 1994\end{array}$

$\begin{array}{llll}5.08 & 5.08 & 6.10 & 12.19\end{array}$

\section{Internal Rate of Return (\%)}

Tax receipts

Living standards

\begin{tabular}{cccccccccc}
10.48 & 8.87 & 7.68 & 6.64 & 8.10 & 9.11 & 8.53 & 8.05 & 6.05 & 6.37 \\
20.68 & 19.38 & 17.69 & 14.83 & 16.84 & 17.57 & 15.77 & 15.26 & 13.08 & 13.15 \\
\hline
\end{tabular}

Note: All values are in billions of US dollars in 2016. Assumptions on number of students and teachers per school, recurrent costs/salaries multiplier, and school lifetime follow Duflo (2001). Schools construction costs are obtained from Duflo (2001), teachers training from Daroesman (1972), and teachers' salaries from various sources (see Appendix C for more details). Benefits are paid by cohorts that could attend the full 6 years of primary education until their death. Breakeven year is the first year when the present discounted value of benefits exceeds that of costs. Tax receipts consist of direct tax expenditures plus $10 \%$ VAT on total expenditures. Living standards is proxied with total household expenditures. Internal rate of return is the discount rate that equates the present discounted value of benefits and costs. 


\title{
Online Appendix for
}

\section{Long-term and Intergenerational Effects of Education: Evidence from School Construction in Indonesia}

\author{
Richard Akresh \\ University of Illinois at Urbana-Champaign \\ Daniel Halim \\ University of Illinois at Urbana-Champaign \\ Marieke Kleemans \\ University of Illinois at Urbana-Champaign
}

November 20, 2018 


\section{A. Online Appendix Figures and Tables}

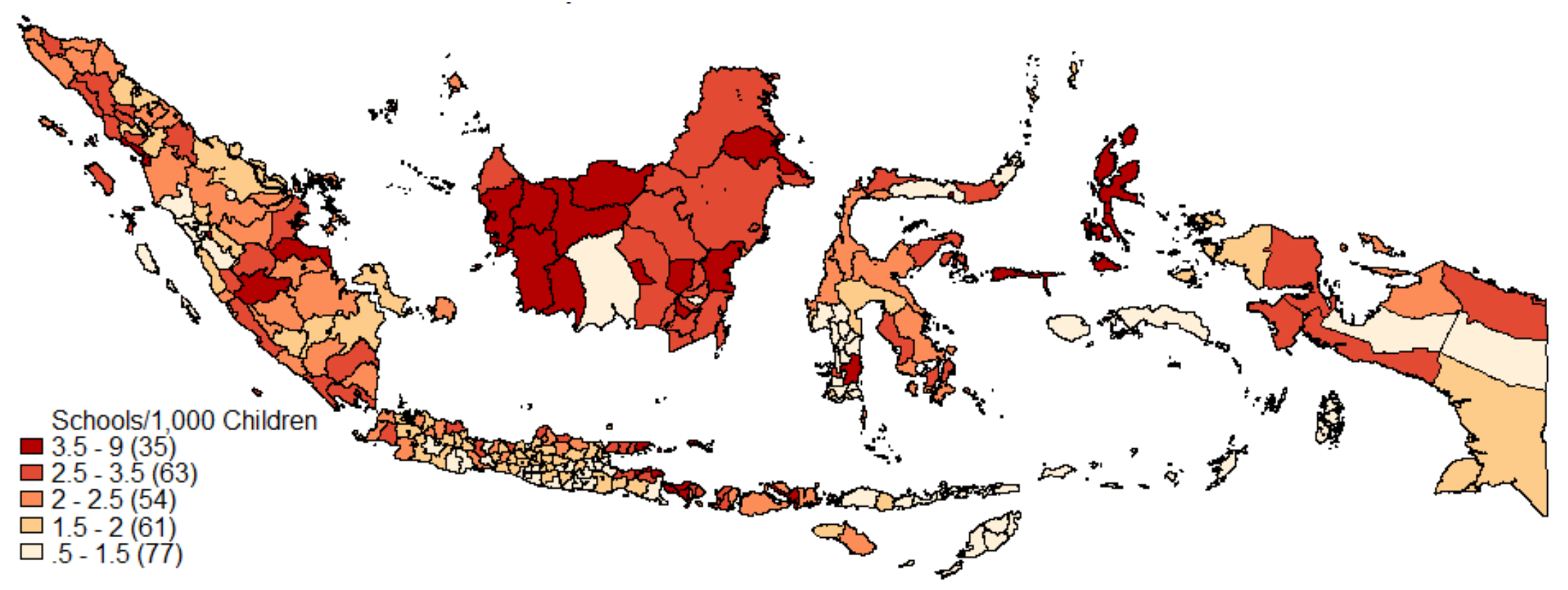

\section{Appendix Figure A.1. Spatial distribution of schools constructed per 1,000 children between 1973 and 1979}

Notes: Number of schools constructed between 1973 and 1979 and children’s population in 1971 are obtained from Duflo (2001) and the Indonesian 1971 Census. The legend indicates the range and distribution of schools constructed across the Indonesian archipelago. The numbers in parentheses refer to the number of districts that fall in that range. The total number of districts, 290, reflects their existence in 1993. Districts often split over time; by March 2016, there were 511 districts. In our analyses, we maintain the 1993 district boundaries to allow matching with Duflo (2001)'s school construction data. 

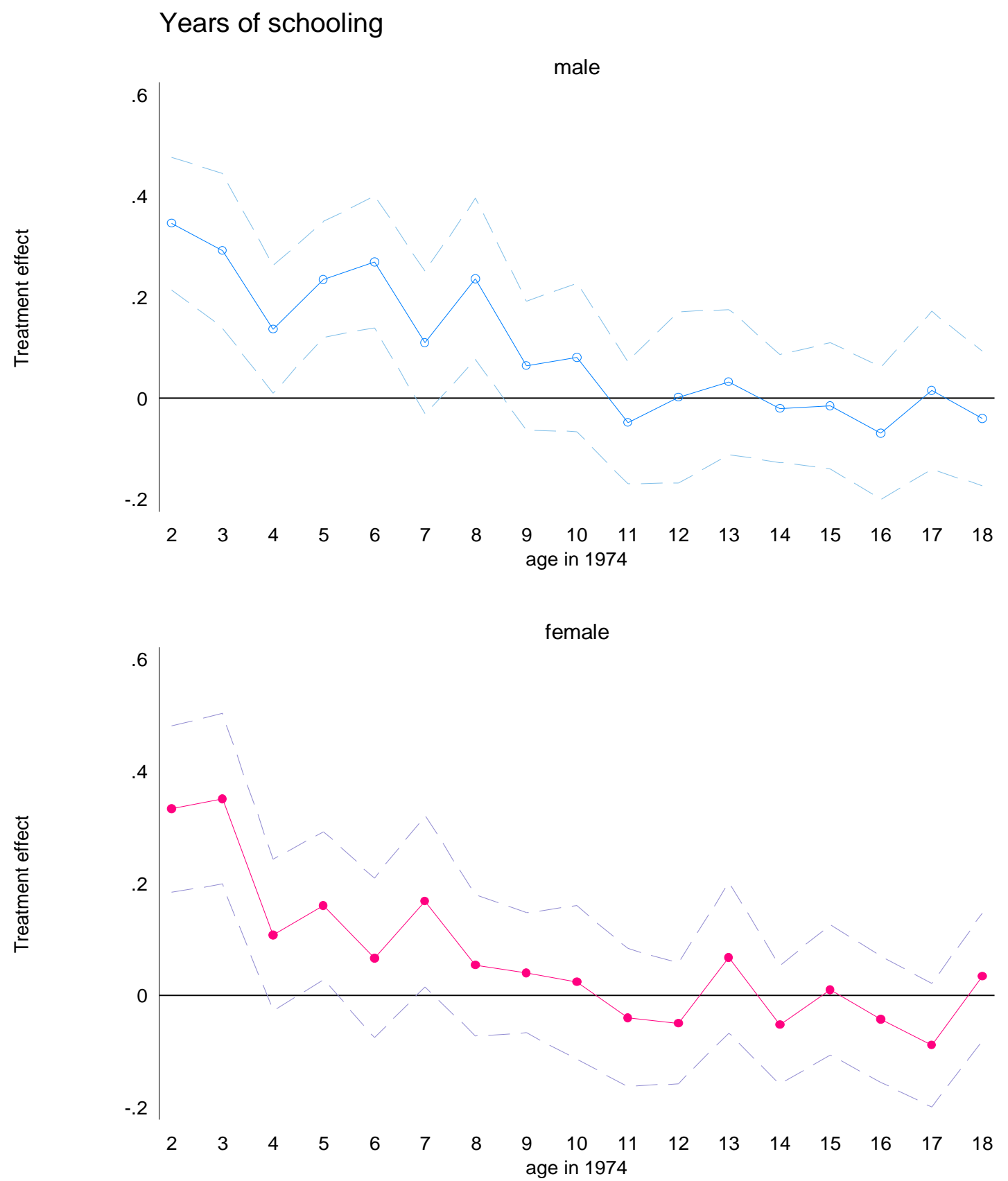

Appendix Figure A.2. Effect of school construction on first generation individual's years of schooling by age in 1974

Notes: Sample is restricted to individuals aged 2-24 in 1974 (born between 1950 and 1972). Each dot represents the interaction coefficient of the number of INPERS primary schools constructed in one's birth district and an age in 1974 dummy. The age group 19-24 is omitted from the regression. The dashed lines represent $95 \%$ confidence bands. 


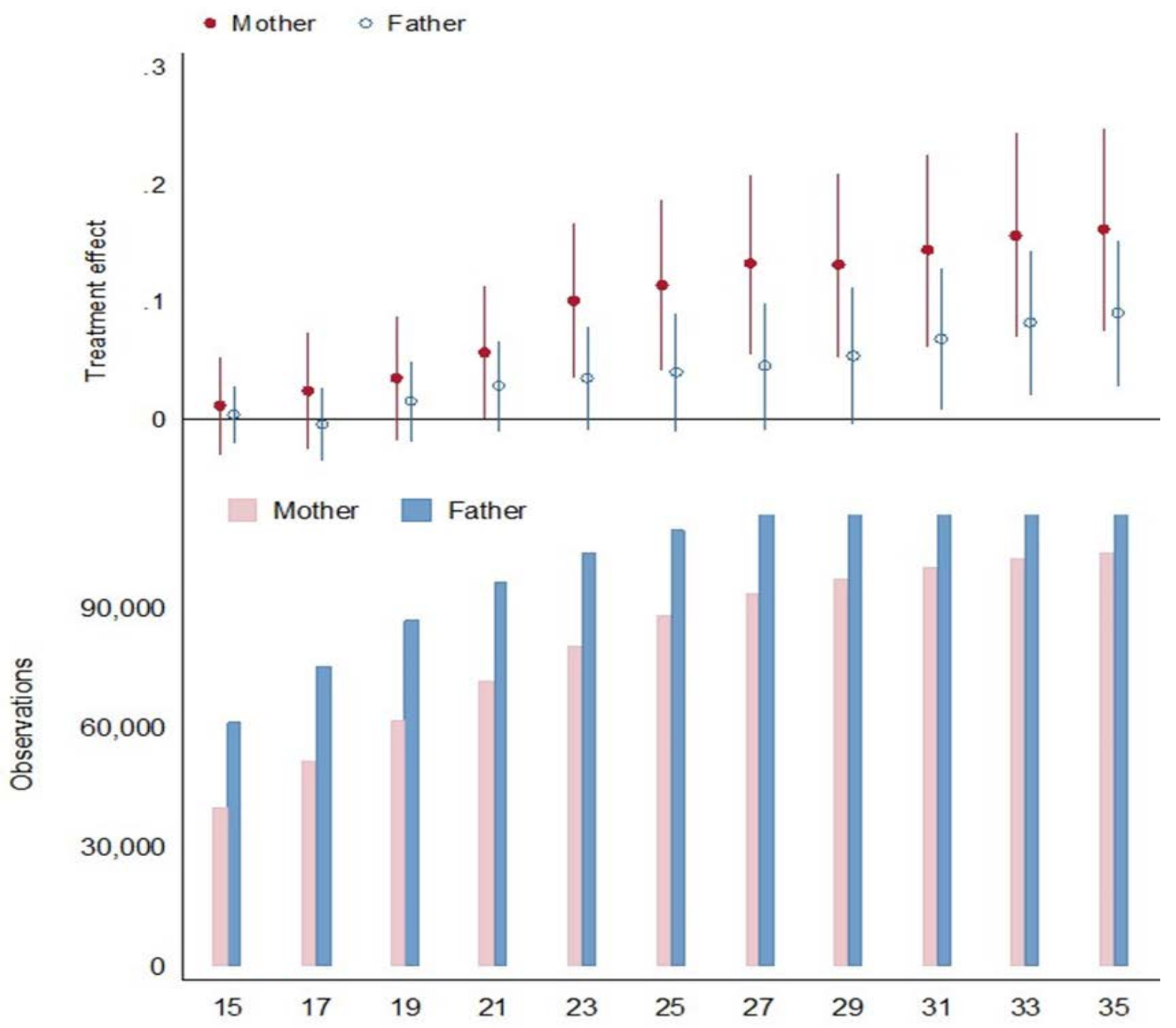

\section{Appendix Figure A.3. Effect of school construction on second generation's years of schooling, using alternative upper-bound age restrictions}

Notes: In the top panel, treatment effects indicate the effect of one additional school constructed per 1,000 children in the mother's or father's birth district on the years of schooling for second generation individuals. Each dot represents a coefficient in a separate regression. We show estimated regression coefficients and their respective 95\% confidence intervals. Sample is restricted to children from age 5 up to the value on the $\mathrm{x}$-axis. Bottom panel shows the number of additional observations added to each regression when the upper-age limit is increased. 


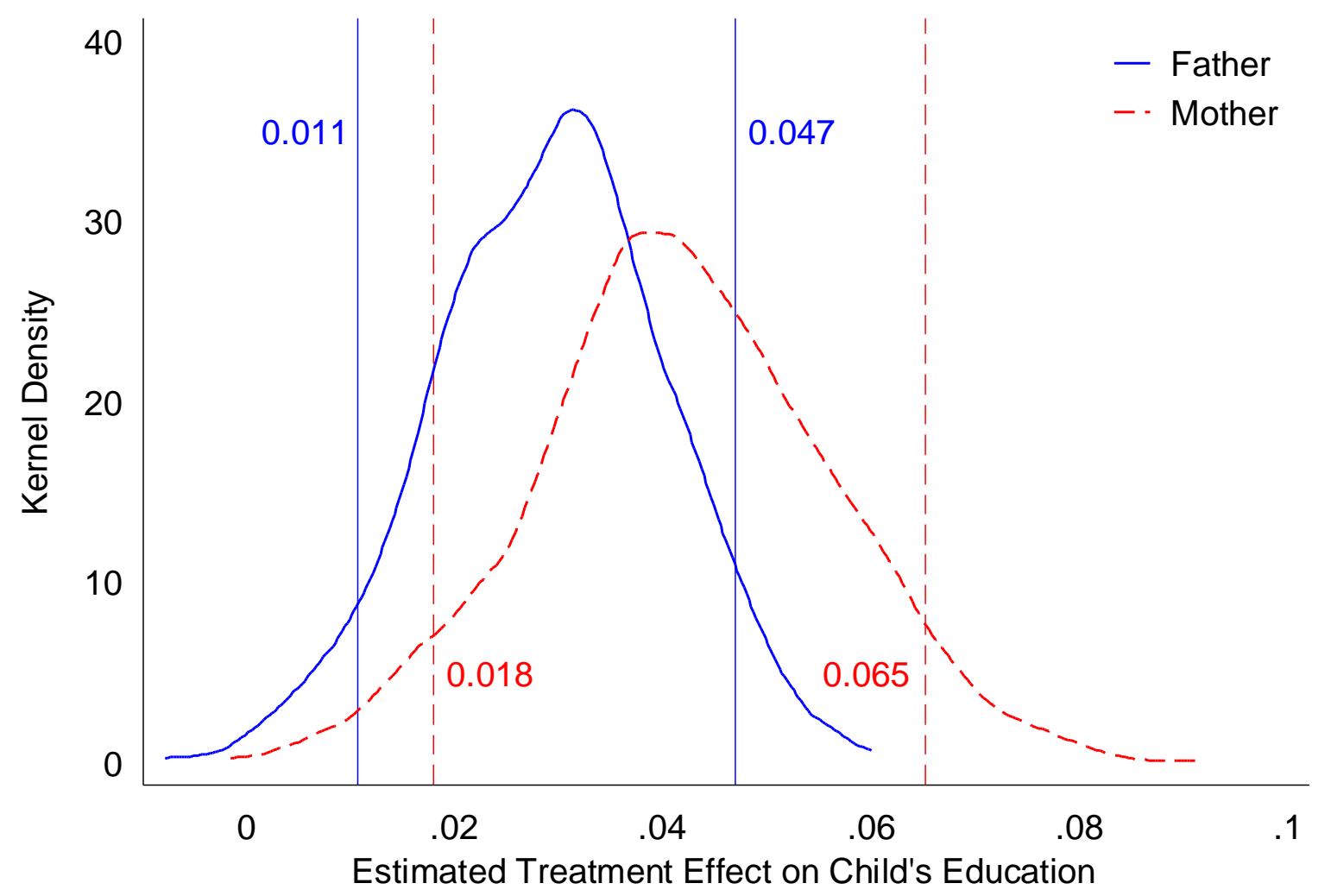

Note: estimates from 1000 random sample drawings; 5th and 95th percentiles indicated.

\section{Appendix Figure A.4. Distribution of estimated treatment effects on second generation's years of schooling from simulated exposure assignment}

Note: To address the selection issue about co-resident second generation children observed in the Susenas data, we use the IFLS to obtain the fraction of children at each age who are born to old and young cohort parents among all children no longer living with their parents. We then use these IFLS-based fractions to randomly assign non-co-resident children at each age in the Susenas data to either old or young cohort parents and to exclude the others from the regression. We then simulate this randomization assignment procedure 1,000 times and estimate the second generation years of schooling regression. This figure plots the density distribution of estimated coefficients from these 1,000 repetitions for father's and mother's exposure to the school construction. Solid lines indicate the distribution of father's effects and dashed lines indicate the distribution of mother's effects. Vertical lines indicate the $5^{\text {th }}$ and $95^{\text {th }}$ percentiles. 

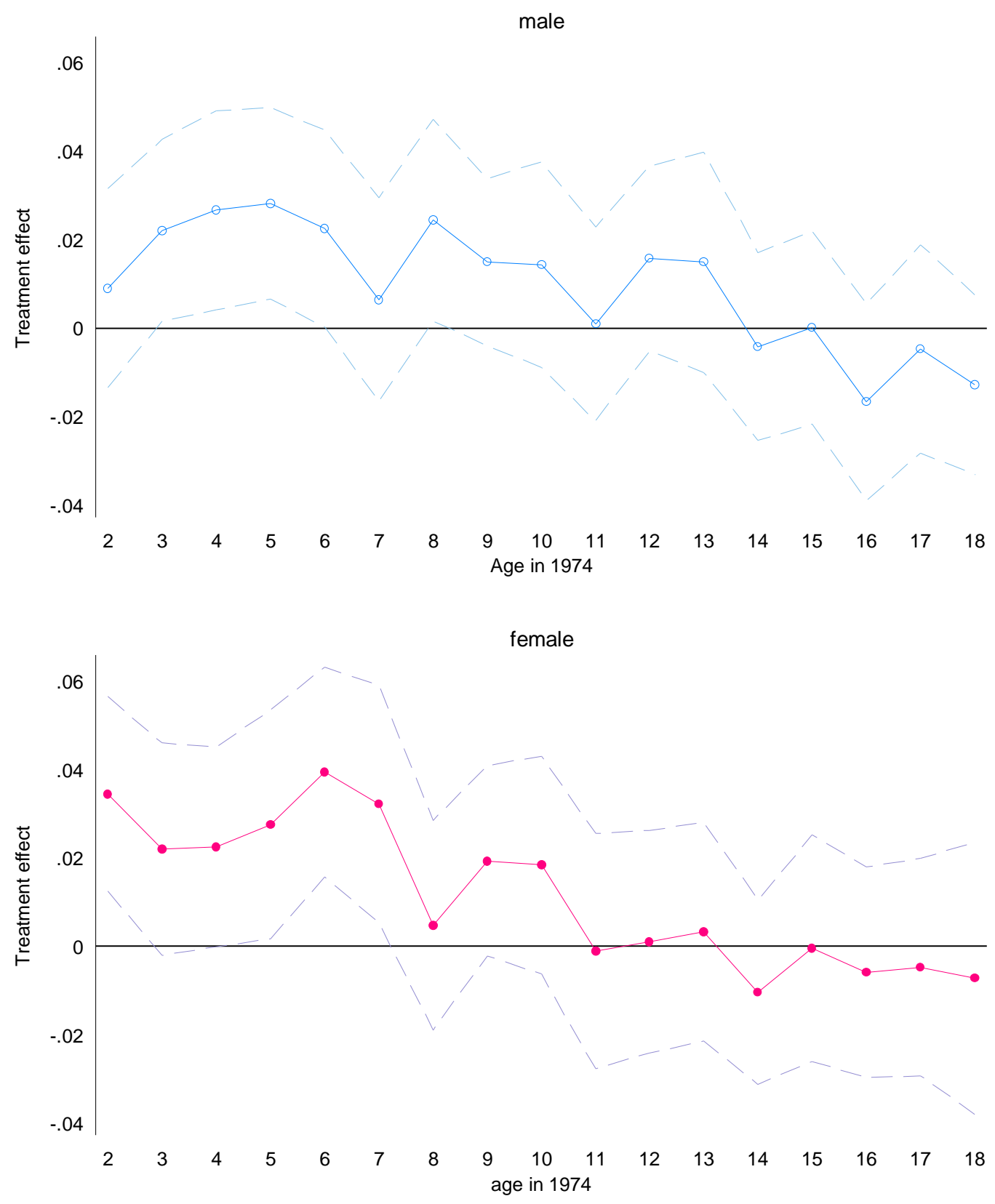

\section{Appendix Figure A.5. Effect of school construction on household expenditures by age in} 1974

Notes: Sample is restricted to individuals aged 2-24 in 1974 (born between 1950 and 1972). Each dot represents the interaction coefficient of the number of INPERS primary schools constructed in one's birth district and an age in 1974 dummy. The age group 19-24 is omitted from the regression. The dashed lines represent 95\% confidence bands. 


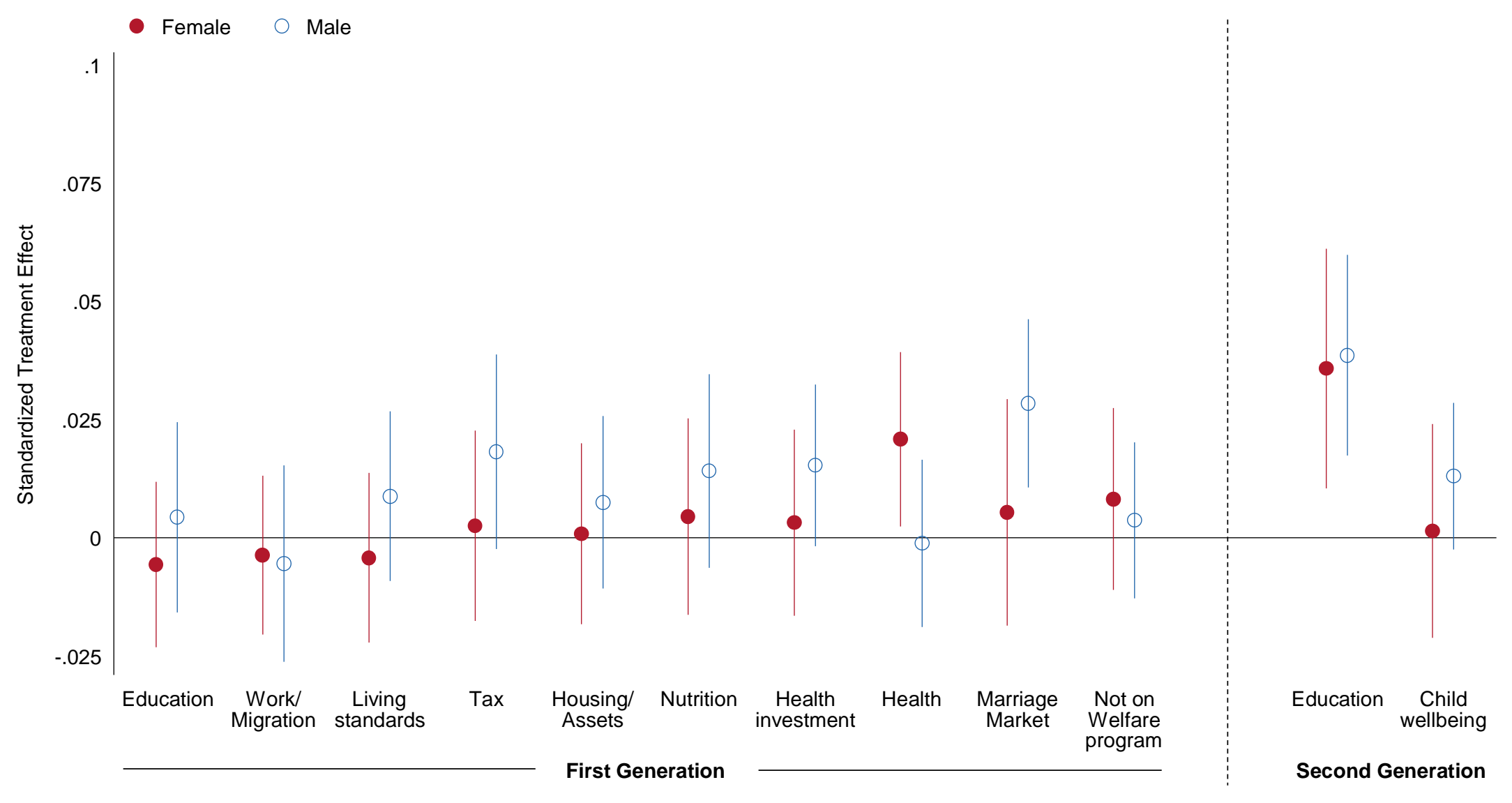

Appendix Figure A.6. Placebo effect of school construction on indexes of long-run outcomes for individuals too old to benefit from primary school construction

Notes: Similar to Figure 1, where we compare individuals born between 1957-1962 (old cohort) and 1968-1972 (young cohort), we now estimate a placebo regression by restricting the sample to individuals born between 1950-1956 (an older cohort) and 1957-1962 (old cohort). Each dot represents the interaction coefficient of the number of INPRES schools built between 1973 and 1979 in one's birth district and a dummy for being born between 1957 and 1962. The solid lines represent 95\% confidence bands. This figure serves as a placebo test since the old cohort was too old to be enrolled in primary school when the schools were constructed, and thus could not benefit from the school construction. The individual outcomes making up the index for each family are listed in Tables 1-7 and Appendix Tables A.1 to A.5. 


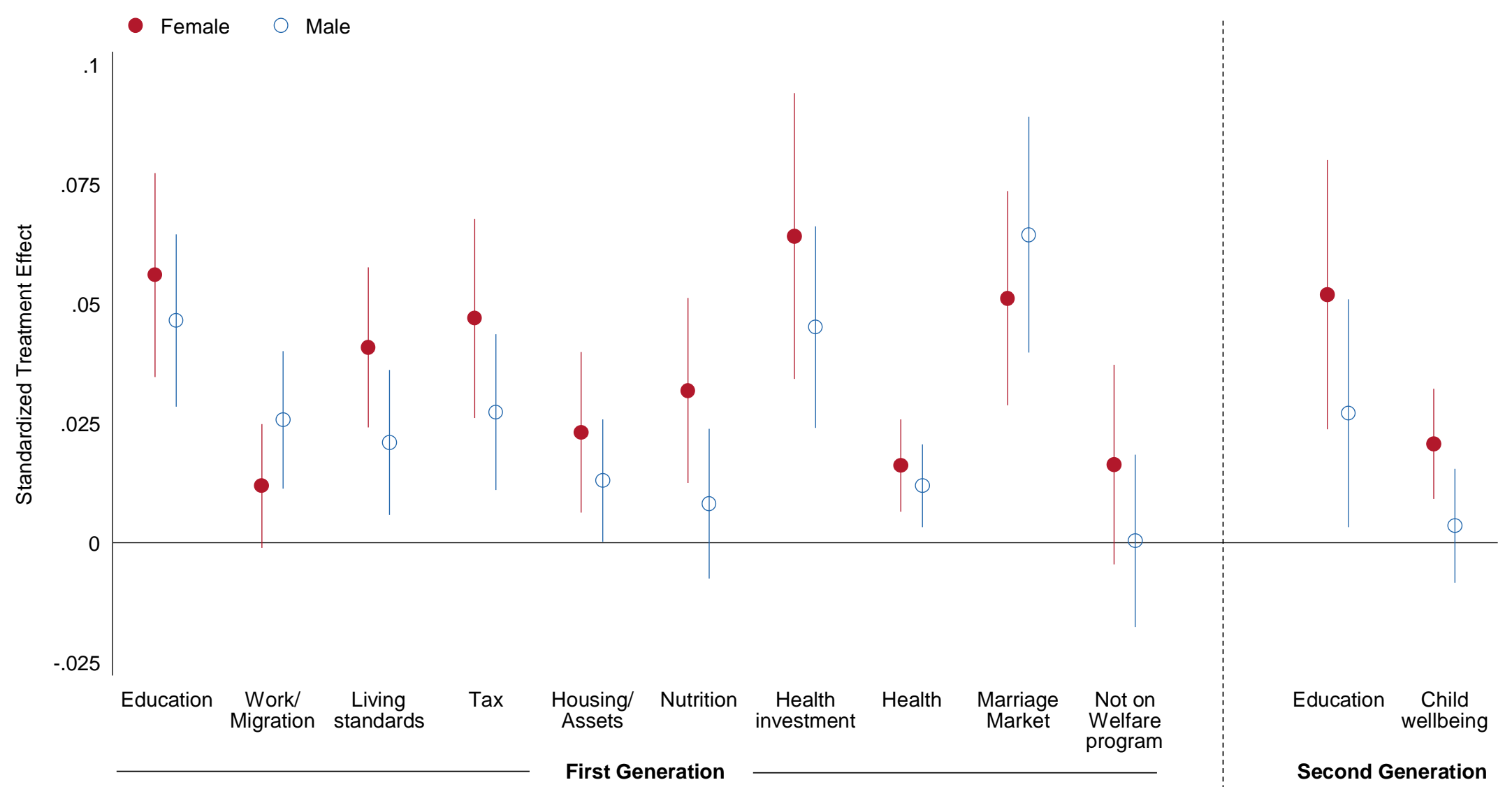

Appendix Figure A.7. Effect of school construction on indexes of long-run outcomes extending the sample to all individuals born between 1950 and 1980

Notes: Similar to Figure 1, but regressions now include all individuals born between 1950 and 1980. Each dot represents the interaction coefficient of the number of INPRES schools built between 1973 and 1979 in one's birth district and a dummy for being born between 1968 and 1980. The solid lines represent 95\% confidence intervals. The individual outcomes making up the index for each family are listed in Tables 1-7 and Appendix Tables A.1 to A.5. 


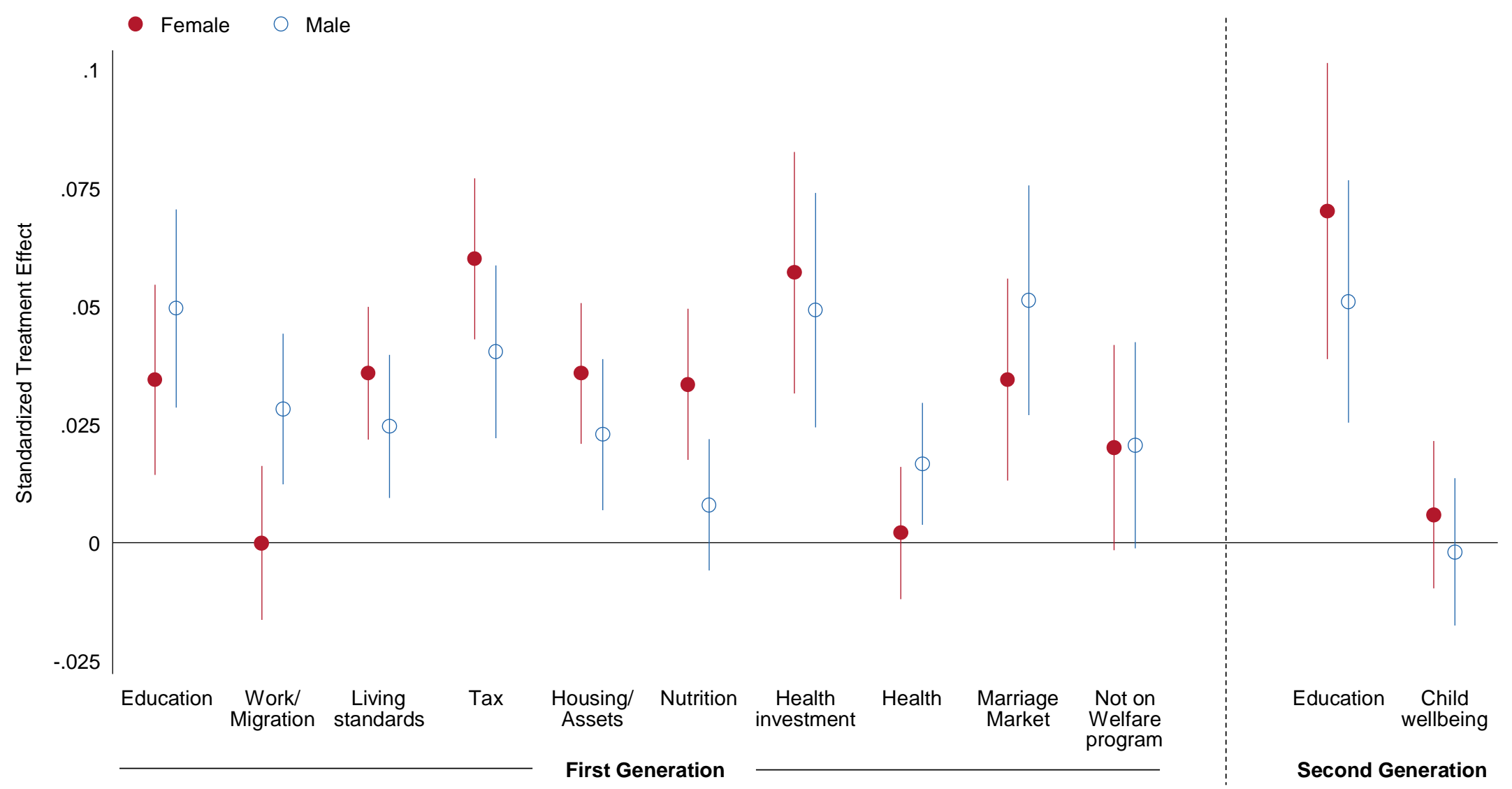

Appendix Figure A.8. Effect of school construction on indexes of long-run outcomes using alternative control variables

Notes: Similar to Figure 1, but regressions now exclude the interaction of birth year dummies and water and sanitation programs from the control variables. Each dot represents the interaction coefficient of the number of INPRES schools built between 1973 and 1979 in one's birth district and a dummy for being born between 1968 and 1972. The solid lines represent 95\% confidence intervals. The individual outcomes making up the index for each family are listed in Tables 1-7 and Appendix Tables A.1 to A.5. 


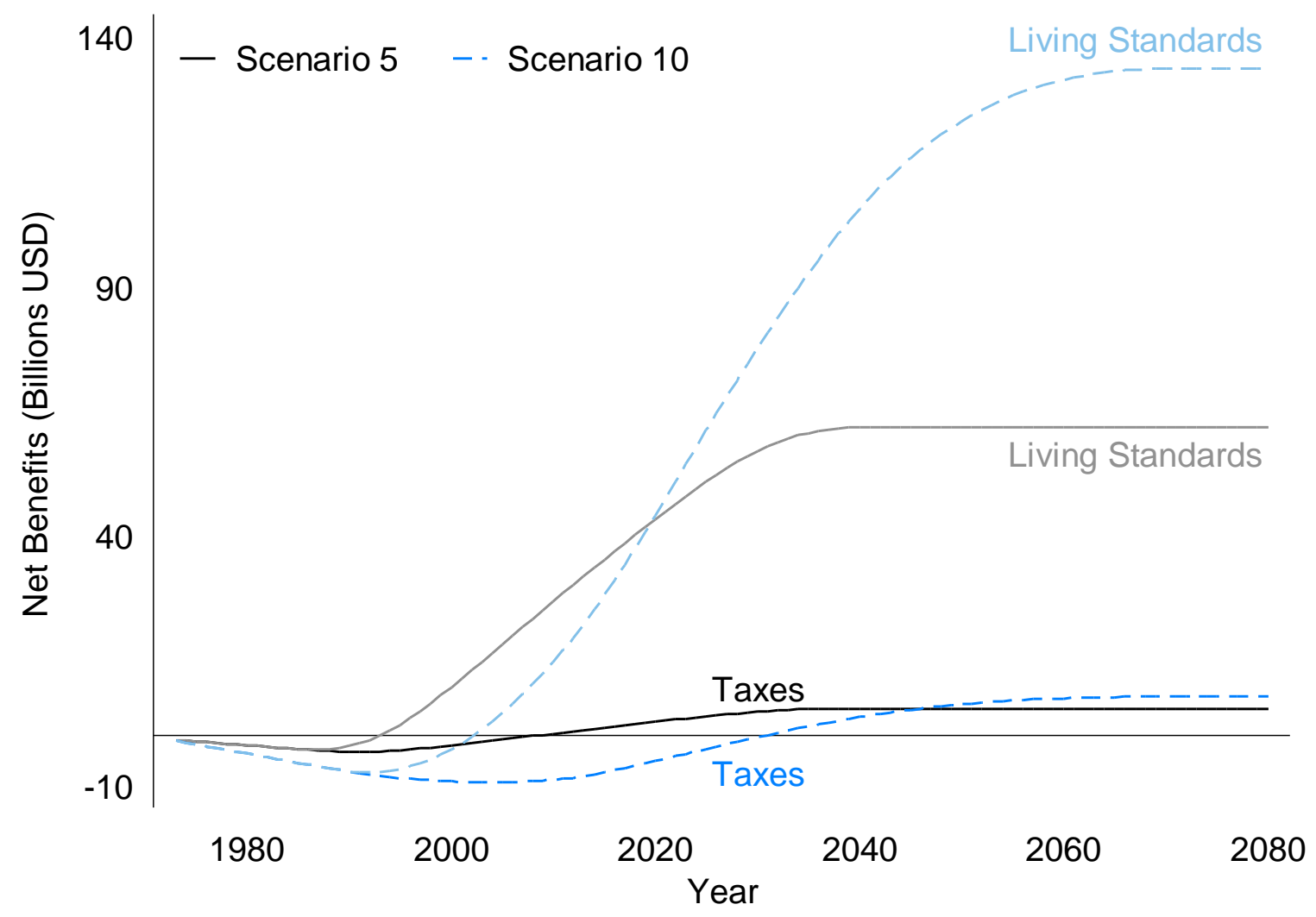

\section{Appendix Figure A.9. Discounted net benefits of school construction in Indonesia}

Note: We plot net benefits (the difference in discounted total benefits and total costs) over time. Benefits are either tax receipts collected by the government or improved living standards of the citizens. Net benefits are reported in billions of 2016 USD. We present two scenarios using the parameters from the cost-benefit model in column (5) and column (10) of Table 11. Solid lines indicate net benefits - in taxes and living standards - under Scenario 5. Dashed lines indicate net benefits under Scenario 10. 
Appendix Table A.1. Effect of school construction on first generation's housing and assets

\begin{tabular}{|c|c|c|c|c|c|}
\hline \multirow[b]{2}{*}{ Outcome } & \multirow[b]{2}{*}{ Description } & \multicolumn{2}{|c|}{ Mean / SD } & \multicolumn{2}{|c|}{$\begin{array}{l}\text { Effect of Program } \\
\text { Exposure on: }\end{array}$} \\
\hline & & Men & Women & Men & Women \\
\hline Urban & Indicator for residing in an urban area & $\begin{array}{r}0.425 \\
(0.494)\end{array}$ & $\begin{array}{r}0.438 \\
(0.496)\end{array}$ & $\begin{array}{l}-0.001 \\
(0.004) \\
{[0.822]}\end{array}$ & $\begin{array}{l}0.002 \\
(0.004) \\
{[0.576]}\end{array}$ \\
\hline $\begin{array}{l}\text { Rent equivalent } \\
\text { (Rp10k) }\end{array}$ & $\begin{array}{l}\text { Actual monthly rent if house is rented, or estimated } \\
\text { rent value if house is owned or leased by the } \\
\text { employer }\end{array}$ & $\begin{array}{c}42.991 \\
(56.342)\end{array}$ & $\begin{array}{c}43.085 \\
(56.573)\end{array}$ & $\begin{array}{l}0.012 \\
(0.008) \\
{[0.293]}\end{array}$ & $\begin{array}{l}0.028 * * * \\
(0.008) \\
{[0.001]}\end{array}$ \\
\hline $\begin{array}{l}\text { Floor area } \\
\qquad\left(\mathrm{m}^{2}\right)\end{array}$ & House’s floor area in square meters & $\begin{array}{c}79.894 \\
(58.651)\end{array}$ & $\begin{array}{c}81.355 \\
(59.726)\end{array}$ & $\begin{array}{l}1.229 * * \\
(0.566) \\
{[0.119]}\end{array}$ & $\begin{array}{l}1.480 * * * \\
(0.510) \\
{[0.011]}\end{array}$ \\
\hline $\begin{array}{l}\text { Utilities } \\
\qquad \text { (Rp10k) }\end{array}$ & Expenditure on electricity, water, gas, and kerosene & $\begin{array}{c}15.714 \\
(20.983)\end{array}$ & $\begin{array}{c}15.729 \\
(21.796)\end{array}$ & $\begin{array}{l}0.051 * * \\
(0.022) \\
{[0.102]}\end{array}$ & $\begin{array}{c}0.085 * * * \\
(0.024) \\
{[0.002]}\end{array}$ \\
\hline Asset index & $\begin{array}{l}\text { PCA index on binary ownerships of motorcycle, car, } \\
\text { home phone, computer, TV, jewelry, refrigerator, } \\
\text { water heater, LPG gas tube, boat, and air conditioner }\end{array}$ & $\begin{array}{l}-0.035 \\
(1.868)\end{array}$ & $\begin{array}{c}-0.069 \\
(1.882)\end{array}$ & $\begin{array}{l}0.030 * \\
(0.017) \\
{[0.223]}\end{array}$ & $\begin{array}{l}0.040 * * \\
(0.015) \\
{[0.020]}\end{array}$ \\
\hline $\begin{array}{l}\text { Housing/Assets } \\
\text { index }\end{array}$ & $\begin{array}{l}\text { Aggregates all } 5 \text { outcomes and standardizes it to the } \\
\text { mean of the old cohort in low-program regions. } \\
\text { Effects are interpreted as standard deviation changes } \\
\text { from the mean. }\end{array}$ & & & $\begin{array}{l}0.021 * * \\
(0.009)\end{array}$ & $\begin{array}{c}0.035 * * * \\
(0.009)\end{array}$ \\
\hline
\end{tabular}

Notes: Effect of program exposure are the regression coefficients of young cohort dummy interacted with the number of schools constructed in region of birth. All regressions control for district of birth and cohort of birth fixed effects, children's population and enrollment in 1971, and water and sanitation program intensities that vary by region of birth interacted with birth year dummies. Robust standard errors clustered at region of birth are shown in parentheses. Stars denote statistical significance at 1 , 5 , and $10 \%$ levels based on unadjusted p-values. FDR q-values are computed over all 5 outcomes and are shown in square brackets. FDR q-values indicate the probability of false positives among significant tests. There are 68,687 and 66,249 observations in the men's and women's regressions, respectively. We apply an inverse hyperbolic sine transformation to all monetary values. Estimates can be interpreted as percentage changes. 


\begin{tabular}{|c|c|c|c|c|c|}
\hline \multirow{2}{*}{ Outcome } & \multirow[b]{2}{*}{ Description } & \multicolumn{2}{|c|}{ Mean / SD } & \multicolumn{2}{|c|}{$\begin{array}{l}\text { Effect of Program } \\
\text { Exposure on: }\end{array}$} \\
\hline & & Men & Women & Men & Women \\
\hline Calories & $\begin{array}{l}\text { Household's accounts of units of food consumed in } \\
\text { the past week (e.g. } 5 \mathrm{~kg} \text { of rice) are converted into } \\
\text { nutritional intake by the Central Statistics Agency. }\end{array}$ & $\begin{array}{c}260.915 \\
(106.001)\end{array}$ & $\begin{array}{c}249.699 \\
(109.833)\end{array}$ & $\begin{array}{c}0.005 \\
(0.004) \\
{[0.301]}\end{array}$ & $\begin{array}{c}0.018 * * * \\
(0.005) \\
{[0.001]}\end{array}$ \\
\hline Protein & $\begin{array}{l}\text { Following their procedure, we convert the weekly } \\
\text { intake to monthly intake. In the regressions, we } \\
\text { apply an inverse hyperbolic transformation for } \\
\text { reasons discussed above. The mean of calories }\end{array}$ & $\begin{array}{r}7.116 \\
(3.254)\end{array}$ & $\begin{array}{c}6.831 \\
(3.330)\end{array}$ & $\begin{array}{c}0.006 \\
(0.005) \\
{[0.301]}\end{array}$ & $\begin{array}{c}0.018 * * * \\
(0.005) \\
{[0.001]}\end{array}$ \\
\hline Fat & $\begin{array}{l}\text { intake is reported in } 1 \mathrm{kcal} \text { increments. The means } \\
\text { of protein, fat, and carbohydrate intakes are reported } \\
\text { in } 1 \mathrm{~kg} \text { increments. }\end{array}$ & $\begin{array}{r}6.074 \\
(3.110)\end{array}$ & $\begin{array}{r}5.810 \\
(3.150)\end{array}$ & $\begin{array}{l}0.011 * * \\
(0.004) \\
{[0.061]}\end{array}$ & $\begin{array}{l}0.023 * * * \\
(0.006) \\
{[0.000]}\end{array}$ \\
\hline Carbohydrates & & $\begin{array}{c}40.869 \\
(17.728)\end{array}$ & $\begin{array}{c}39.040 \\
(18.245)\end{array}$ & $\begin{array}{c}0.005 \\
(0.004) \\
{[0.301]}\end{array}$ & $\begin{array}{l}0.017 * * * \\
(0.005) \\
{[0.001]}\end{array}$ \\
\hline Nutrition index & $\begin{array}{l}\text { Aggregates all } 4 \text { outcomes and standardizes it to the } \\
\text { mean of the old cohort in low-program regions. } \\
\text { Effects are interpreted as standard deviation changes } \\
\text { from the mean. }\end{array}$ & & & $\begin{array}{c}0.014 \\
(0.009)\end{array}$ & $\begin{array}{c}0.039 * * * \\
(0.010)\end{array}$ \\
\hline \multicolumn{6}{|c|}{$\begin{array}{l}\text { Notes: Effect of program exposure are the regression coefficients of young cohort dummy interacted with the number of schools } \\
\text { constructed in region of birth. All regressions control for district of birth and cohort of birth fixed effects, children's population } \\
\text { and enrollment in 1971, and water and sanitation program intensities that vary by region of birth interacted with birth year } \\
\text { dummies. Robust standard errors clustered at region of birth are shown in parentheses. Stars denote statistical significance at } 1 \text {, } \\
5 \text {, and } 10 \% \text { levels based on unadjusted p-values. FDR q-values are computed over all } 5 \text { outcomes and are shown in square } \\
\text { brackets. FDR q-values indicate the probability of false positives among significant tests. There are } 68,687 \text { and } 66,249 \\
\text { observations in the men's and women's regressions, respectively. We apply an inverse hyperbolic sine transformation in the } \\
\text { regressions. Estimates can be interpreted as percentage changes. }\end{array}$} \\
\hline
\end{tabular}




\begin{tabular}{|c|c|c|c|c|c|}
\hline \multirow[b]{2}{*}{ Outcome } & \multirow[b]{2}{*}{ Description } & \multicolumn{2}{|c|}{ Mean / SD } & \multicolumn{2}{|c|}{$\begin{array}{l}\text { Effect of Program } \\
\text { Exposure on: } \\
\end{array}$} \\
\hline & & Men & Women & Men & Women \\
\hline $\begin{array}{l}\text { Total health } \\
\text { expenditure } \\
\text { (Rp10k) }\end{array}$ & $\begin{array}{l}\text { Total monthly household health expenditures, which } \\
\text { aggregates curative, medicine, and preventive health } \\
\text { expenditures }\end{array}$ & $\begin{array}{c}7.517 \\
(34.130)\end{array}$ & $\begin{array}{c}7.961 \\
(35.245)\end{array}$ & $\begin{array}{r}0.071 * \\
(0.038) \\
{[0.114]}\end{array}$ & $\begin{array}{r}0.055 \\
(0.041) \\
{[0.185]}\end{array}$ \\
\hline $\begin{array}{l}\text { Preventive } \\
\text { measures } \\
(\mathrm{Rp} 10 \mathrm{k})\end{array}$ & $\begin{array}{l}\text { Consist of pregnancy checks, immunizations, medical } \\
\text { check-ups, family planning, and other expenditures, e.g., } \\
\text { vitamins, massage, gym memberships }\end{array}$ & $\begin{array}{c}0.744 \\
(3.225)\end{array}$ & $\begin{array}{c}0.671 \\
(3.135)\end{array}$ & $\begin{array}{l}0.242 * * * \\
(0.068) \\
{[0.002]}\end{array}$ & $\begin{array}{l}0.193 * * * \\
(0.071) \\
{[0.013]}\end{array}$ \\
\hline $\begin{array}{l}\text { Family planning } \\
\qquad(\mathrm{Rp} 10 \mathrm{k})\end{array}$ & $\begin{array}{l}\text { A sub-category under preventive health expenditures, } \\
\text { which includes costs of contraceptives and consultations }\end{array}$ & $\begin{array}{c}0.286 \\
(0.872)\end{array}$ & $\begin{array}{c}0.219 \\
(0.856)\end{array}$ & $\begin{array}{l}0.321 * * * \\
(0.061) \\
{[0.000]}\end{array}$ & $\begin{array}{l}0.226 * * * \\
(0.071) \\
{[0.008]}\end{array}$ \\
\hline $\begin{array}{l}\text { Private hospital } \\
\text { (Rp10k) }\end{array}$ & $\begin{array}{l}\text { A sub-category under curative health expenditures and is } \\
\text { distinct from expenditures on public hospitals, clinics, } \\
\text { and traditional healers }\end{array}$ & $\begin{array}{c}2.101 \\
(20.718)\end{array}$ & $\begin{array}{c}2.200 \\
(22.266)\end{array}$ & $\begin{array}{l}0.048 * * \\
(0.023) \\
{[0.114]}\end{array}$ & $\begin{array}{l}0.075^{* * *} \\
(0.024) \\
{[0.008]}\end{array}$ \\
\hline $\begin{array}{l}\text { Health insurance } \\
\qquad(\mathrm{Rp} 10 \mathrm{k})\end{array}$ & $\begin{array}{l}\text { Health insurance is distinct from life, accidental, vehicle, } \\
\text { and house insurances }\end{array}$ & $\begin{array}{c}3.821 \\
(16.425)\end{array}$ & $\begin{array}{c}3.635 \\
(14.047)\end{array}$ & $\begin{array}{c}0.083 \\
(0.055) \\
{[0.134]}\end{array}$ & $\begin{array}{l}0.142 * * * \\
(0.048) \\
{[0.009]}\end{array}$ \\
\hline $\begin{array}{l}\text { Health investment } \\
\quad \text { index }\end{array}$ & $\begin{array}{l}\text { Aggregates all } 5 \text { outcomes and standardizes it to the } \\
\text { mean of the old cohort in low-program regions. Effects } \\
\text { are interpreted as standard deviation changes from the } \\
\text { mean. }\end{array}$ & & & $\begin{array}{l}0.065^{* * *} \\
(0.015)\end{array}$ & $\begin{array}{c}0.063 * * * \\
(0.016)\end{array}$ \\
\hline
\end{tabular}

Notes: Effect of program exposure are the regression coefficients of young cohort dummy interacted with the number of schools constructed in region of birth. All regressions control for district of birth and cohort of birth fixed effects, children's population and enrollment in 1971, and water and sanitation program intensities that vary by region of birth interacted with birth year dummies. Robust standard errors clustered at region of birth are shown in parentheses. Stars denote statistical significance at 1,5 , and $10 \%$ levels based on unadjusted p-values. FDR q-values are computed over all 5 outcomes and are shown in square brackets. FDR qvalues indicate the probability of false positives among significant tests. There are 68,687 and 66,249 observations in the men's and women's regressions, respectively. We apply an inverse hyperbolic sine transformation to all monetary values. Estimates can be interpreted as percentage changes. 


\begin{tabular}{|c|c|c|c|c|c|}
\hline \multirow{2}{*}{ Outcome } & \multirow[b]{2}{*}{ Description } & \multicolumn{2}{|c|}{ Mean / SD } & \multicolumn{2}{|c|}{$\begin{array}{l}\text { Effect of Program } \\
\text { Exposure on: }\end{array}$} \\
\hline & & Men & Women & Men & Women \\
\hline Cash Transfer & $\begin{array}{l}\text { Unconditional cash transfer to compensate for the removal } \\
\text { of gas price subsidy for poor households }\end{array}$ & $\begin{array}{c}0.041 \\
(0.197)\end{array}$ & $\begin{array}{r}0.039 \\
(0.194)\end{array}$ & $\begin{array}{l}-0.002 \\
(0.002) \\
{[0.742]}\end{array}$ & $\begin{array}{l}-0.001 \\
(0.002) \\
{[0.914]}\end{array}$ \\
\hline Rice for Poor & Monthly rice allowance for poor households & $\begin{array}{r}0.392 \\
(0.488)\end{array}$ & $\begin{array}{r}0.406 \\
(0.491)\end{array}$ & $\begin{array}{c}0.002 \\
(0.004) \\
{[0.850]}\end{array}$ & $\begin{array}{l}-0.009 * \\
(0.005) \\
{[0.200]}\end{array}$ \\
\hline $\begin{array}{r}\text { Poor Student's } \\
\text { Assistance }\end{array}$ & Cash transfer conditional on school enrollment & $\begin{array}{r}0.056 \\
(0.363)\end{array}$ & $\begin{array}{c}0.127 \\
(0.333)\end{array}$ & $\begin{array}{l}-0.001 \\
(0.004) \\
{[0.850]}\end{array}$ & $\begin{array}{c}0.000 \\
(0.004) \\
{[0.914]}\end{array}$ \\
\hline $\begin{array}{l}\text { Social Protection } \\
\text { Card }\end{array}$ & $\begin{array}{l}\text { Card provided to poor households, which entitles them to } \\
\text { social welfare programs mentioned above }\end{array}$ & $\begin{array}{r}0.186 \\
(0.389)\end{array}$ & $\begin{array}{r}0.180 \\
(0.384)\end{array}$ & $\begin{array}{l}-0.001 \\
(0.004) \\
{[0.850]}\end{array}$ & $\begin{array}{l}-0.000 \\
(0.004) \\
{[0.914]}\end{array}$ \\
\hline $\begin{array}{l}\text { Welfare program } \\
\text { non- } \\
\text { participation } \\
\text { index }\end{array}$ & $\begin{array}{l}\text { Aggregates all } 4 \text { outcomes and standardizes it to the mean } \\
\text { of the old cohort in low-program regions. Effects are } \\
\text { interpreted as standard deviation changes from the mean. } \\
\text { For the index, we reverse the sign for the } 4 \text { welfare } \\
\text { programs to indicate a positive outcome. }\end{array}$ & & & $\begin{array}{r}0.006 \\
(0.011)\end{array}$ & $\begin{array}{c}0.010 \\
(0.012)\end{array}$ \\
\hline
\end{tabular}

Notes: Means indicate the fraction of program recipients. Effect of program exposure are the regression coefficients of young cohort dummy interacted with the number of schools constructed in region of birth. All regressions control for district of birth and cohort of birth fixed effects, children's population and enrollment in 1971, and water and sanitation program intensities that vary by region of birth interacted with birth year dummies. Robust standard errors clustered at region of birth are shown in parentheses. Stars denote statistical significance at 1, 5, and 10\% levels based on unadjusted p-values. FDR q-values are computed over all 4 outcomes and are shown in square brackets. FDR q-values indicate the probability of false positives among significant tests. There are 68,687 and 66,249 observations in the men’s and women's regressions, respectively. 


\begin{tabular}{|c|c|c|c|c|c|}
\hline \multirow[b]{2}{*}{ Outcome } & \multirow[b]{2}{*}{ Description } & \multicolumn{2}{|c|}{ Mean / SD } & \multicolumn{2}{|c|}{$\begin{array}{l}\text { Effect of Program } \\
\text { Exposure by: }\end{array}$} \\
\hline & & Father & Mother & $\begin{array}{l}\text { Fathers on } \\
\text { Children }\end{array}$ & $\begin{array}{c}\text { Mothers on } \\
\text { Children }\end{array}$ \\
\hline Non-work days & $\begin{array}{l}\text { Number of days not worked in the past week by the } \\
\text { child unconditional on work, i.e. } 7 \text { for non-working } \\
\text { individuals }\end{array}$ & $\begin{array}{l}5.317 \\
(2.670)\end{array}$ & $\begin{array}{c}4.820 \\
(2.865)\end{array}$ & $\begin{array}{l}0.044 * * \\
(0.021) \\
{[0.136]}\end{array}$ & $\begin{array}{l}0.031 \\
(0.019) \\
{[0.463]}\end{array}$ \\
\hline Non-work hours & $\begin{array}{l}\text { Number of hours not worked in the past week by the } \\
\text { child unconditional on work, i.e. } 168 \text { for non-working } \\
\text { individuals }\end{array}$ & $\begin{array}{l}156.679 \\
(19.704)\end{array}$ & $\begin{array}{l}153.047 \\
(21.597)\end{array}$ & $\begin{array}{l}0.299 * \\
(0.157) \\
{[0.173]}\end{array}$ & $\begin{array}{l}0.215 \\
(0.151) \\
{[0.463]}\end{array}$ \\
\hline $\begin{array}{l}\text { No health } \\
\text { complaint }\end{array}$ & $\begin{array}{l}\text { Self-reported indicator defined as } 1 \text { if child did not } \\
\text { experience a health complaint in the past month }\end{array}$ & $\begin{array}{c}0.797 \\
(0.402)\end{array}$ & $\begin{array}{c}0.823 \\
(0.382)\end{array}$ & $\begin{array}{c}-0.008 * * * \\
(0.003) \\
{[0.042]}\end{array}$ & $\begin{array}{l}0.004 \\
(0.003) \\
{[0.463]}\end{array}$ \\
\hline $\begin{array}{l}\text { Non-disrupted } \\
\text { days }\end{array}$ & $\begin{array}{l}\text { Self-reported number of days in the past month } \\
\text { (maximum of } 30 \text { days) that a health complaint did not } \\
\text { disrupt child's daily activities }\end{array}$ & $\begin{array}{l}29.492 \\
(2.086)\end{array}$ & $\begin{array}{l}29.550 \\
(2.067)\end{array}$ & $\begin{array}{l}-0.026^{*} \\
(0.016) \\
{[0.198]}\end{array}$ & $\begin{array}{l}0.007 \\
(0.015) \\
{[0.893]}\end{array}$ \\
\hline $\begin{array}{l}\text { No severe health } \\
\text { complaint }\end{array}$ & $\begin{array}{l}\text { Self-reported indicator defined as } 1 \text { if child did not } \\
\text { experience a severe health complaint in the past month }\end{array}$ & $\begin{array}{c}0.978 \\
(0.147)\end{array}$ & $\begin{array}{c}0.980 \\
(0.140)\end{array}$ & $\begin{array}{l}-0.000 \\
(0.001) \\
{[0.751]}\end{array}$ & $\begin{array}{l}-0.000 \\
(0.001) \\
{[0.893]}\end{array}$ \\
\hline $\begin{array}{l}\text { Second generation } \\
\text { wellbeing } \\
\text { index }\end{array}$ & $\begin{array}{l}\text { Aggregates all } 5 \text { outcomes and standardizes it to the } \\
\text { mean of the old cohort in low-program regions. Effects } \\
\text { are interpreted as standard deviation changes from the } \\
\text { mean. }\end{array}$ & & & $\begin{array}{l}-0.004 \\
(0.009)\end{array}$ & $\begin{array}{l}0.017^{* *} \\
(0.008)\end{array}$ \\
\hline
\end{tabular}

\footnotetext{
Notes: Effect of program exposure are the regression coefficients of father or mother's young cohort dummy interacted with the number of schools constructed in father or mother's region of birth. All regressions control for parent's district of birth and cohort of birth fixed effects, child age fixed effects, children's population and enrollment in 1971, and water and sanitation program intensities that vary by region of birth interacted with birth year dummies. Robust standard errors clustered at parent's region of birth are shown in parentheses. Stars denote statistical significance at 1, 5, and 10\% levels based on unadjusted p-values. FDR q-values are computed over all 5 outcomes and are shown in square brackets. FDR q-values indicate the probability of false positives among significant tests. The survey restricts questions on labor market outcomes to individuals aged 10 and older; questions on health outcomes are asked to all individuals. There are 100,293 and 94,067 observations in the father's and mother's regressions for labor market outcomes; 129,971 and 108,607 observations in the father's and mother's regressions for health outcomes.
} 


\section{Appendix Table A.6. Spouse's characteristics as mediators of the effect of school construction on first generation's living}

standards

\begin{tabular}{|c|c|c|c|c|c|c|c|c|c|c|}
\hline \multirow{2}{*}{ Mediator: } & \multicolumn{10}{|c|}{ Dependent Variable: Living standards } \\
\hline & $(1)$ & $(2)$ & (3) & $(4)$ & $(5)$ & $(6)$ & $(7)$ & (8) & (9) & (10) \\
\hline \multicolumn{11}{|l|}{ Panel A: Father } \\
\hline $\begin{array}{l}\text { Schools } \\
\text { constructed } * \\
\text { Young cohort }\end{array}$ & $\begin{array}{c}0.021 * * * \\
(0.007)\end{array}$ & $\begin{array}{c}0.009 \\
(0.008)\end{array}$ & $\begin{array}{c}0.007 \\
(0.007)\end{array}$ & $\begin{array}{c}0.010 \\
(0.007)\end{array}$ & $\begin{array}{c}0.020^{* * *} \\
(0.008)\end{array}$ & $\begin{array}{c}0.019 * * \\
(0.009)\end{array}$ & $\begin{array}{c}0.017 * * \\
(0.008)\end{array}$ & $\begin{array}{c}0.018 * * \\
(0.008)\end{array}$ & $\begin{array}{c}0.020 * * * \\
(0.008)\end{array}$ & $\begin{array}{c}0.008 \\
(0.009)\end{array}$ \\
\hline Observations & 68,687 & 64,416 & 64,416 & 64,416 & 64,416 & 39,545 & 39,545 & 64,416 & 64,416 & 39,545 \\
\hline Mean & 8.011 & 8.068 & 8.068 & 8.068 & 8.068 & 8.007 & 8.007 & 8.068 & 8.068 & 8.007 \\
\hline \multicolumn{11}{|l|}{ Panel B: Mother } \\
\hline $\begin{array}{l}\text { Schools } \\
\quad \text { constructed } * \\
\text { Young cohort }\end{array}$ & $\begin{array}{c}0.032 * * * \\
(0.007)\end{array}$ & $\begin{array}{c}0.016 * * \\
(0.008)\end{array}$ & $\begin{array}{c}0.015 * * \\
(0.007)\end{array}$ & $\begin{array}{c}0.017 * * \\
(0.007)\end{array}$ & $\begin{array}{c}0.023^{* * *} \\
(0.007)\end{array}$ & $\begin{array}{c}0.018 * * \\
(0.007)\end{array}$ & $\begin{array}{c}0.018 * * \\
(0.007)\end{array}$ & $\begin{array}{c}0.021^{* * *} \\
(0.007)\end{array}$ & $\begin{array}{c}0.023 * * * \\
(0.007)\end{array}$ & $\begin{array}{c}0.012 \\
(0.007)\end{array}$ \\
\hline Mean & 7.152 & 7.313 & 7.313 & 7.313 & 7.313 & 7.323 & 7.323 & 7.313 & 7.313 & 7.323 \\
\hline \multicolumn{11}{|c|}{$\begin{array}{l}\text { Notes: Each column shows a regression of the first generation's living standards on exposure to the school construction program and includes a potential } \\
\text { mediator variable. These mediator variables (as indicated by the column heading) are spouse's characteristics in Table } 9 \text {. Regressions are as in row } 1 \\
\text { of Table 3. Effect of program exposure are the regression coefficients of father or mother's young cohort dummy interacted with the number of schools } \\
\text { constructed in father or mother's region of birth. All regressions control for parent's district of birth and cohort of birth fixed effects, children's } \\
\text { population and enrollment in 1971, and water and sanitation program intensities that vary by region of birth interacted with birth year dummies. Robust } \\
\text { standard errors clustered at parent's region of birth are shown in parentheses. Stars denote statistical significance at } 1,5 \text {, and } 10 \% \text { levels based on } \\
\text { unadjusted p-values. }\end{array}$} \\
\hline
\end{tabular}


Appendix Table A.7. Effect of school construction on second generation's years of schooling on various samples

\begin{tabular}{|c|c|c|c|c|c|c|}
\hline & \multicolumn{3}{|c|}{ Susenas with Extreme } & \multicolumn{3}{|c|}{ IFLS } \\
\hline & $(1)$ & $\begin{array}{c}(2) \\
\text { Assume Not } \\
\text { Exposed } \\
\end{array}$ & $\begin{array}{c}\text { (3) } \\
\text { Assume } \\
\text { Exposed }\end{array}$ & $\begin{array}{l}(4) \\
\text { All }\end{array}$ & $\begin{array}{c}(5) \\
\text { Stayers }\end{array}$ & $\begin{array}{c}(6) \\
\text { Movers }\end{array}$ \\
\hline Panel A: Father & & & & & & \\
\hline $\begin{array}{l}\text { Schools constructed } * \\
\text { Young cohort }\end{array}$ & $\begin{array}{c}0.097 * * * \\
(0.032)\end{array}$ & $\begin{array}{c}0.021 \\
(0.016)\end{array}$ & $\begin{array}{c}0.000 \\
(0.014)\end{array}$ & $\begin{array}{c}0.103 \\
(0.104)\end{array}$ & $\begin{array}{c}0.030 \\
(0.109)\end{array}$ & $\begin{array}{l}-0.020 \\
(0.251)\end{array}$ \\
\hline $\begin{array}{l}\text { Observations } \\
\text { Mean }\end{array}$ & $\begin{array}{c}120,838 \\
7.967\end{array}$ & $\begin{array}{c}644,675 \\
7.731\end{array}$ & $\begin{array}{c}644,675 \\
7.731\end{array}$ & $\begin{array}{l}6,186 \\
7.807\end{array}$ & $\begin{array}{l}4,048 \\
6.434\end{array}$ & $\begin{array}{c}2,138 \\
10.396\end{array}$ \\
\hline $\begin{array}{l}\text { Panel B: Mother } \\
\text { Schools constructed * } \\
\text { Young cohort }\end{array}$ & $\begin{array}{c}0.169 * * * \\
(0.045)\end{array}$ & $\begin{array}{c}0.052 * * * \\
(0.017)\end{array}$ & $\begin{array}{l}0.030^{*} \\
(0.017)\end{array}$ & $\begin{array}{l}0.300 * * \\
(0.147)\end{array}$ & $\begin{array}{c}0.539 * * * \\
(0.128)\end{array}$ & $\begin{array}{c}0.126 \\
(0.239)\end{array}$ \\
\hline $\begin{array}{l}\text { Observations } \\
\text { Mean }\end{array}$ & $\begin{array}{c}105,523 \\
8.854\end{array}$ & $\begin{array}{c}644,675 \\
7.731\end{array}$ & $\begin{array}{c}644,675 \\
7.731\end{array}$ & $\begin{array}{l}7,227 \\
9.038\end{array}$ & $\begin{array}{l}3,756 \\
8.097\end{array}$ & $\begin{array}{c}3,471 \\
10.034\end{array}$ \\
\hline
\end{tabular}

Note: Column (1) is from Table 11. Column (2) and (3) estimate extreme bounds in which all non-co-resident children aged 0-40 are assumed to have parents who are either exposed or not exposed (Manski, 1990). Columns (4)-(6) use the IFLS 2014 Round 5 data. We match parents to their co-resident children ("Stayers") found in the household roster and to their non-co-resident children ("Movers") in the respective module. 
Appendix Table A.8. Effect of school construction on first generation's years of schooling (extended cohort definitions)

\begin{tabular}{lccccc}
\hline & $(1)$ & $(2)$ & $(3)$ & $(4)$ & $(5)$ \\
Cohorts Included: & $1957-1962$ & $\ldots+$ & $\ldots+$ & $\ldots+$ & \\
& and & $1950-1956$ & $1963-1967$ & $1973-1980$ & $1950-1980$ \\
& $1968-1972$ & & & & \\
\hline Panel A: Male & & & & & \\
Schools constructed * & $0.268 * * *$ & $0.267 * * *$ & $0.221^{* * *}$ & $0.211^{* * *}$ & $0.172 * * *$ \\
$\quad$ Young cohort & $(0.047)$ & $(0.039)$ & $(0.037)$ & $(0.044)$ & $(0.032)$ \\
\hline Observations & 72,367 & 98,895 & 98,781 & 138,617 & 197,951 \\
Mean & 8.022 & 7.500 & 7.938 & 8.478 & 8.047 \\
\hline Panel B: Female & & & & & \\
Schools constructed $*$ & $0.234 * * *$ & $0.219 * * *$ & $0.209 * * *$ & $0.245 * * *$ & $0.210 * * *$ \\
$\quad$ Young cohort & $(0.042)$ & $(0.044)$ & $(0.039)$ & $(0.044)$ & $(0.045)$ \\
\hline Observations & 71,423 & 97,268 & 99,843 & 140,142 & 200,644 \\
Mean & 7.105 & 6.496 & 6.901 & 7.790 & 7.194 \\
\hline
\end{tabular}

Notes: Robust standard errors clustered at region of birth are shown in parentheses. Stars denote statistical significance at 1,5 , and $10 \%$ levels based on unadjusted p-values. Column (1) sample is restricted to individuals born in the sample period 1957-1962 (old cohort) and 1968-1972 (younger cohort) and is the sample used in the analysis in the rest of the paper. Columns (2) to (5) extend the sample as indicated in the column headings. Panel A looks only at males and Panel B only at females. School constructed denotes the number of INPRES schools constructed per 1,000 children in one's birth district. Young cohort is an indicator defined as 1 for being born after 1967. 
Appendix Table A.9. Effect of school construction on first generation's household expenditures (various transformations)

\begin{tabular}{|c|c|c|c|c|c|c|c|c|}
\hline & \multicolumn{4}{|c|}{ Total expenditure } & \multicolumn{4}{|c|}{ Education expenditure } \\
\hline & $\begin{array}{c}\text { IHS Total } \\
(1)\end{array}$ & $\begin{array}{l}\text { Log } \\
\text { (2) }\end{array}$ & Nominal & $\begin{array}{c}\text { IHS Per- } \\
\text { capita } \\
(4)\end{array}$ & $\begin{array}{l}\text { IHS } \\
\text { Total } \\
(5)\end{array}$ & $\begin{array}{l}\text { Log } \\
(6)\end{array}$ & $\begin{array}{c}\text { Nominal } \\
(7)\end{array}$ & $\begin{array}{c}\text { IHS Per- } \\
\text { capita } \\
(8)\end{array}$ \\
\hline \multicolumn{9}{|l|}{ Panel A: Father } \\
\hline $\begin{array}{l}\text { Schools constructed * } \\
\text { Young cohort }\end{array}$ & $\begin{array}{c}0.021^{* * *} \\
(0.007)\end{array}$ & $\begin{array}{c}0.021 * * * \\
(0.007)\end{array}$ & $\begin{array}{c}9.882 * * * \\
(3.628) \\
\end{array}$ & $\begin{array}{c}0.016 * * \\
(0.007) \\
\end{array}$ & $\begin{array}{l}0.160 * * \\
(0.064)\end{array}$ & $\begin{array}{c}0.013 \\
(0.010) \\
\end{array}$ & $\begin{array}{c}0.309 \\
(0.309) \\
\end{array}$ & $\begin{array}{r}0.140 * * \\
(0.056)\end{array}$ \\
\hline Observations & 68,687 & 68,687 & 68,687 & 68,687 & 68,687 & 48,123 & 68,687 & 68,687 \\
\hline Mean & 391.649 & 391.649 & 391.649 & 391.649 & 13.971 & 13.971 & 13.971 & 13.971 \\
\hline \multicolumn{9}{|l|}{ Panel B: Mother } \\
\hline $\begin{array}{l}\text { Schools constructed * } \\
\text { Young cohort }\end{array}$ & $\begin{array}{c}0.032 * * * \\
(0.007)\end{array}$ & $\begin{array}{c}0.032 * * * \\
(0.007)\end{array}$ & $\begin{array}{l}11.022 * * * \\
(2.583)\end{array}$ & $\begin{array}{c}0.018 * * * \\
(0.007)\end{array}$ & $\begin{array}{l}0.193 * * \\
(0.076)\end{array}$ & $\begin{array}{l}-0.010 \\
(0.014)\end{array}$ & $\begin{array}{l}-0.191 \\
(0.383)\end{array}$ & $\begin{array}{l}0.167 * * \\
(0.067)\end{array}$ \\
\hline Observations & 66,249 & 66,249 & 66,249 & 66,249 & 66,249 & 39,492 & 66,249 & 66,249 \\
\hline Mean & 375.616 & 375.616 & 375.616 & 375.616 & 12.202 & 12.202 & 12.202 & 12.202 \\
\hline
\end{tabular}

Notes: Effect of program exposure are the regression coefficients of young cohort dummy interacted with the number of schools constructed in region of birth. All regressions control for district of birth and cohort of birth fixed effects, children's population and enrollment in 1971, and water and sanitation program intensities that vary by region of birth interacted with birth year dummies. Robust standard errors clustered at region of birth are shown in parentheses. Stars denote statistical significance at 1 , 5, and 10\% levels based on unadjusted p-values. All expenditure values are defined at the household level and refer to the household's average monthly expenditure. Nominal values are reported in 10,000 Indonesian Rupiah (IDR) increments. In 2016, the average daily exchange rates was 1 USD=13,308 IDR. Columns (1)-(4) examine total household expenditure; columns (5)(8) examine education expenditure. Inverse hyperbolic sine (IHS) transformations are applied to total and per capita household expenditures (columns 1 and 4) and to total and per-capita education expenditures (columns 5 and 8). Log transformations are applied in columns (2) and (6). Column (1) and (5) are the preferred specification and are the same as Table 3, rows 1 and 5. 


\section{B. Data Appendix}

Two critical data issues about the Susenas 2016 survey are relevant for our analysis. First, to estimate the difference-in-differences specification described in Section 3.1, it is necessary to have information about an individual's residence at birth. Current residence could be endogenous to the school construction program as households might move to provide access to schools to their children. Location of birth and location where the individual obtains their education are highly correlated. ${ }^{1}$ However, birth location is not endogenous with respect to the school construction since all of the individuals in the analysis were born before the program started. Given the importance of knowing where the individual was born, it is unfortunate that most household surveys in Indonesia only provide information about the individual's current location of residence. This lack of information about an individual's birth location is the case for the Indonesian Labor Force Survey (Sakernas), the Indonesian Demographic and Health Surveys (DHS), and many other rounds of the Susenas data, making them unavailable to use to analyze the impacts of the school construction program. However, the Susenas 2016 is one exception to this, as there is information on every individual's district of birth.

Second, it is important that the data include a sufficiently large sample of individuals from these specific birth cohorts (1957-1962 and 1968-1972). The Indonesia Family Life Survey (IFLS) does contain information on each individual's region of residence at birth, thus satisfying the first criteria we outline above. We use the IFLS data to estimate our main difference-indifference specification exploiting variation across birth cohorts and regions in the number of schools built. The IFLS is a longitudinal survey, and the first round was collected in 1993/1994. Subsequent rounds were collected in 1997, 2000, 2007/2008, and most recently in 2014/2015. Tracking across rounds has been extremely successful, with rates between 92 to 95 percent for each IFLS round (Thomas et. al., 2012). Almost 88 percent of households in survey round one were subsequently interviewed in all of the five survey rounds. In columns 1-3 of Appendix Table B.1, we use the most recent survey round collected in 2014/2015 (IFLS 5) and include all individuals interviewed in that round in the regressions. In columns 4-6, we begin with the IFLS 5 and then add in any other individuals from the other four rounds who might no longer be present in the final round of the panel survey. We estimate regressions with different control variables to see if that has any influence on the results. Column 3 (IFLS 5 only) and column 6 (IFLS 5 plus last observed round) correspond with our main results for men and women in Table 1 row 1 . We do not observe any statistically significant relationship between exposure to the school construction and increased years of schooling.

The IFLS and Susenas data have two key differences that might be relevant to explain this situation. First, the Susenas data is nationally representative covering all 34 provinces and all 511 districts in the country. IFLS is representative of only $83 \%$ of the Indonesian population and covers individuals living in 13 out of 27 provinces in the country. Appendix Figure B.1 shows a map of Indonesian districts with the districts shaded in gray indicating which ones the IFLS survey covers. Comparing Figure 2 (map of Indonesia indicating the spatial distribution of school constructed per 1,000 children) and Appendix Figure B.1 highlights that many of the

\footnotetext{
${ }^{1}$ Based on the IFLS data, almost 92 percent of children at age 12 still live in the same district where they were born (Duflo, 2001). Likewise, in the Susenas 2016, 93.2 percent of children at age 12 live in the same district where they were born.
} 
districts that had many schools constructed are not included in the IFLS survey. In column 7 of Appendix Table B.1, we present results using the Susenas 2016 data but restricting the analysis to only those districts covered in the IFLS survey. The coefficients from the regression with this restricted sample are somewhat smaller ( 0.211 for men and 0.166 for women) compared to the full sample from Table 1 ( 0.268 for men and 0.234 for women), but the results are still statistically significant and economically meaningful. This is evidence that the different geographic coverage of the IFLS and the Susenas is unlikely to explain the lack of relationship between school construction and years of schooling in the IFLS data (columns 1-6). Second, note that the number of observations in the IFLS regressions for women is only 2,546 if using only IFLS 5 or 2,783 if using IFLS 5 plus the last observed round for any individual. ${ }^{2}$ This compares with 71,423 observations for women in the regression using the Susenas data. While the point estimates for women are similar across the two datasets, this difference in sample size could explain the much larger standard errors in the regressions using IFLS data.

${ }^{2}$ Using the extended cohort of individuals born between 1950 and 1980 roughly triples the sample size (for men to 7,093 and 7,666 and for women to 7,382 and 8,018 in the IFLS 5 and IFLS 5 plus last observed round, respectively), but the results are still not statistically significant. 
Appendix Table B.1. Effect of school construction on first generation's education using IFLS data

\begin{tabular}{|c|c|c|c|c|c|c|c|}
\hline Dependent variable: Years of schooling & IFLs & $(2014 / 2$ & (3) & IFLS 5 & ast obser & d round & $\begin{array}{c}\text { Susenas } 2016 \\
\text { restricted to IFLS } \\
\text { districts } \\
(7) \\
\end{array}$ \\
\hline \multicolumn{8}{|l|}{ Panel A: Male } \\
\hline Schools constructed $*$ Young cohort & $\begin{array}{c}-0.144 \\
(0.141)\end{array}$ & $\begin{array}{c}-0.122 \\
(0.148)\end{array}$ & $\begin{array}{c}-0.032 \\
(0.187)\end{array}$ & $\begin{array}{c}-0.224 \\
(0.160)\end{array}$ & $\begin{array}{c}-0.186 \\
(0.173)\end{array}$ & $\begin{array}{l}-0.220 \\
(0.204)\end{array}$ & $\begin{array}{c}0.211^{* * *} \\
(0.063)\end{array}$ \\
\hline Observations & 2,389 & 2,389 & 2,389 & 2,609 & 2,609 & 2,609 & 54,646 \\
\hline Children population in 1971 & X & X & X & X & X & X & $\mathrm{X}$ \\
\hline Enrollment in 1971 & & $\mathrm{X}$ & $\mathrm{X}$ & & $\mathrm{X}$ & $\mathrm{X}$ & $\mathrm{X}$ \\
\hline Water and sanitation program & & & $\mathrm{X}$ & & & $\mathrm{X}$ & $\mathrm{X}$ \\
\hline \multicolumn{8}{|l|}{ Panel B: Female } \\
\hline Schools constructed ${ }^{*}$ Young cohort & $\begin{array}{c}0.037 \\
(0.174)\end{array}$ & $\begin{array}{c}0.053 \\
(0.176)\end{array}$ & $\begin{array}{c}0.207 \\
(0.214)\end{array}$ & $\begin{array}{c}0.215 \\
(0.151)\end{array}$ & $\begin{array}{c}0.229 \\
(0.148)\end{array}$ & $\begin{array}{c}0.318 \\
(0.198)\end{array}$ & $\begin{array}{c}0.166 * * * \\
(0.056)\end{array}$ \\
\hline Observations & 2,546 & 2,546 & 2,546 & 2,783 & 2,783 & 2,783 & 54,508 \\
\hline Children population in 1971 & $\mathrm{X}$ & $\mathrm{X}$ & X & X & $\mathrm{X}$ & X & $\mathrm{X}$ \\
\hline Enrollment in 1971 & & $X$ & $X$ & & $X$ & $X$ & $\mathrm{X}$ \\
\hline Water and sanitation program & & & $X$ & & & $\mathrm{X}$ & $\mathrm{X}$ \\
\hline
\end{tabular}

Notes: Effects of program exposure are the regression coefficients of young cohort dummy interacted with the number of schools constructed in region of birth. Standard errors clustered at region of birth are shown in parentheses. Stars denote statistical significance at 1, 5, and 10\% levels based on regular p-values. Columns 1-3 uses Indonesia Family Life Survey data, Round 5 (2014/2015). Columns 4-6 uses IFLS round 5 data plus the observation from the last observed round for any individual not in round

5. Column 7 uses Susenas 2016 data that is restricted to the IFLS districts, which cover $83 \%$ of the Indonesian population. 


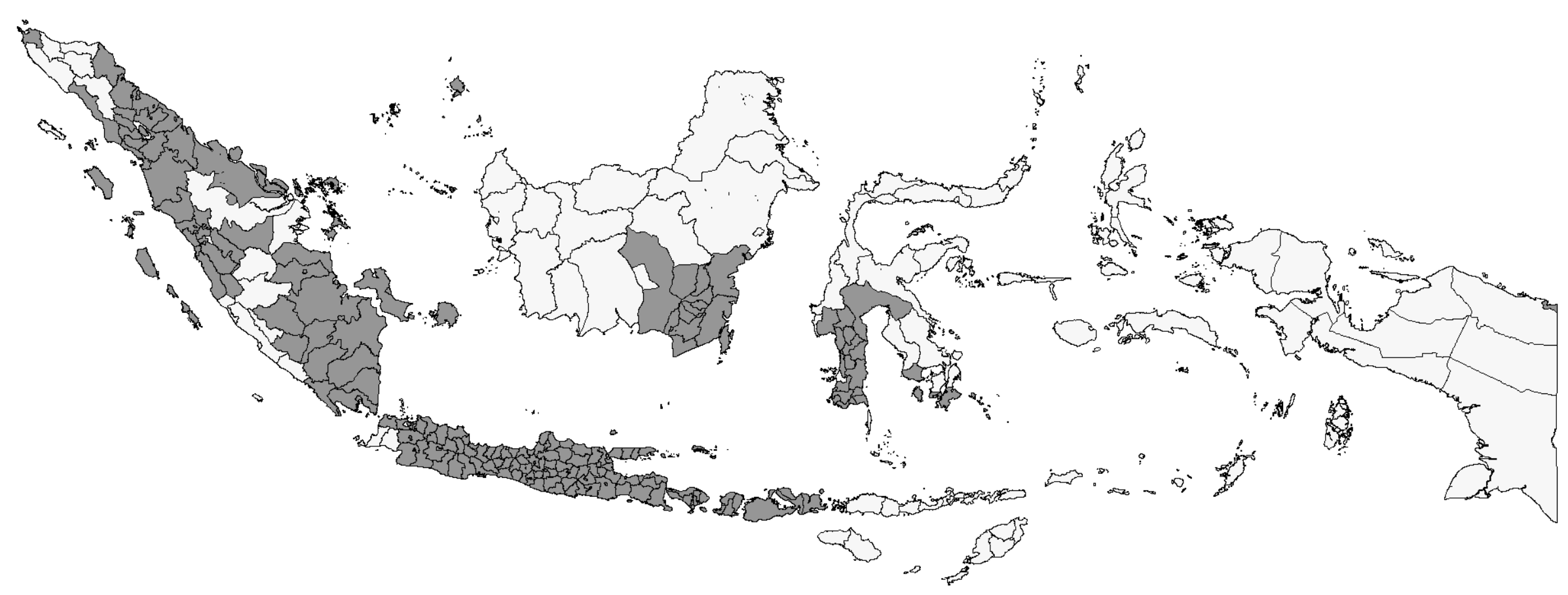

Appendix Figure B.1. Map of Indonesia with districts shaded in gray indicating coverage in Indonesia Family Life Survey (IFLS)

Notes: IFLS survey is representative of $83 \%$ of the Indonesian population and covers individuals living in 13 of the 27 provinces in the country. The districts shaded in gray are included in the IFLS household survey, while the Susenas 2016 used in the main analysis in the paper is nationally representative and includes all districts in the country. 


\section{Cost-benefit Calculations Appendix}

\section{Discount rate}

World Development Indicators collects real interest rates in Indonesia between 1987 and 2017. It averages 5.77 percent per year. Since it does not extend as far as our sample period in 1973, we assume a constant annual discount rate of 5 percent.

Teachers' salary growth

We first assume there is no real salary growth over the years and use Duflo (2001)'s reported teacher's salary in 1973. Subsequently, we allow for linear growth using teacher's salary observations in 1970 by Daroesman (1972), 1973 by Duflo (2001), Intercensal Surveys 1976 and 1995, and Labor Force Surveys 2000, 2005 and 2010. ${ }^{3}$ Teachers are paid for the lifetime of the schools

\section{Lifetime curvature}

Individuals' tax payments and living standards generally follow an inverted-U shape, where they peak at around age 40-50. In our Susenas data, we observe individuals at their peak. To model the lifetime curvature of tax payments and living standards, we assume the same average effect on taxes and living standards across ages but different means at different ages. A 20-year old male, for instance, only spends $\$ 2,373$ annually, compared to the mean in of our observed sample, \$3,531, as implied in Table 3.

\section{GDP/capita growth}

GDP per-capita growth is obtained from World Development Indicators. We took the average between 1961 and 2017: 3.25 percent per year.

Number of students and teachers per school and recurrent costs/salaries multiplier We follow Duflo (2001) in assuming 120 students/school, 3 teachers/school, and 25\% recurrent administrative costs in addition to teachers' salaries. These imply a class size of 20 students across 6 grades of primary education and 1 teacher per grade. The latter is reasonable given that schools often run two sessions per day: morning and afternoon classes.

Individuals start paying taxes after age 18

We first assume that individuals start paying taxes after finishing Upper Secondary education at age 18. We subsequently relax this assumption to age 22, after individuals finish Tertiary education.

\section{School lifetime}

Daroesman (1971) and Duflo (2001) report that schools were expected to last for 20 years. We first use this assumption. We subsequently relax this assumption to 40 years because many INPRES schools are still in-use as of 2016.

\section{Life expectancy}

\footnotetext{
${ }^{3}$ We drop Duflo (2001)'s reported salary in 1995 because it implies a 9 percent real growth per year and it is much higher than the linear fit would have predicted. It is also higher than observations in 2000, 2005, and 2010.
} 
World Development Indicators suggest an average of 56.6 years of life expectancy at birth for individuals born between 1968 and 1980. Conditional on making it to primary school age, the life expectancy is likely higher. We assume a life expectancy of 60 years throughout and then relax this assumption in the final column.

Share of men and women in affected cohorts

We construct a weighted average of the treatment effects on men and women. The share of women in the affected cohort is 0.498 . For simplicity, we assume an equal share of men and women. 